

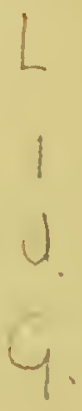

Presented by the Executors of Norman Douglas Simpson

$$
\text { I } 890 \text { - I } 974
$$




\section{Nature Pictures}

A Magnificent Volume, size of Page, $121^{\prime \prime} \times 10^{\prime \prime}$, containing SEVERAL HUNDREDS of ILLUSTRATIONS, every one from life, and quite difterent from those in our "Nature Books," by the best nature-photographers, of birds, animals, fishes, flowers, fungi, insects, etc.

\section{Bound in Cloth Gilt, $7 / 6$ net}

Can also be had in Twelve 6d. Parts, which can be purchased separately.

Speclal Features of some of the Parls:

Part 3 contains a beautiful series of plates of the Oyster-catcher, Part 4 of the nittiwake Gull, Part 7 of the Sandwich Tern, Part 10 of the Gannet and of the Little Ter'n, and Part 11 of the Common Tern, but every part is full of beautiful photographs.

LONDON \& GLASGOW: GOWANS \& GRAY, LTD. 


\section{Gowans's Nature Books}

$\Gamma^{H E}$ object of these little books is to stimulate a love for nature and a desire to study it. All the volumes of the series that have been issued so far have been very successful, and the publishers hope to be able to maintain the very high standard of excellence which has made this series so well known all over the country. Some of the photo. graphs included in the different volumes are unequalled and unique triumphs of the nature. photographer's art.

No. x.-WILD BIRDS AT HOME. SIxty Photo. graphs from Life, by Chas. Kirk, of British Birds and their Nests.

No. 2.-WILD FLOWERS AT HOME. First Series. Sixty Photograplis from Nature, by Cameron Todd.

No. 3.-WILD FLOWERS AT HOME. Second Series. By the Same.

No. 4.-BUTTERFLIES AND MOTHS AT HOME. Sixty Photographs from Life, by A. Forrester.

No. 5.-WILD BIRDS AT HOME. Second Series. By Chas. Kirk.

No. 6.-FRESHWATER FISHES. Sixty Photographs from Life, by Walford $B$. Johnson and Stanley $C$. Johnson, M.A.

No. 7.-TOADSTOOLS AT HOME. Sixty Photographs of Fungi, by Somerville Hastings, F.R.C.S.

No. 8.- OUR TREES \& HOW TO KNOW THEM. Sixty Photographs by Chas. Kirl:.

No. 9.-WILD FLOWERS AT HOME. Third Series. By Somerville Hastiugs, F.R.C.S.

No. so.-LIFE IN THE ANTARCTIC. Sixty Photographs from Life by Members of the Scottish National Antarctic Fixpedition.

Natural History Museum Library

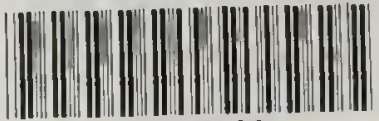

000097200 
No. 11.-REPTILE LIFE. Sixiy Pho:ographs from Life, by $W$ alford $B$. Johnson and Sianley $C$. Johnson, M.A.

No. 12.-SEA-SHORE LIFE. Sixty Photographs by the Same.

No. 13.-BIRDS AT THE ZOO. Sixty Photographs from Life, by W. S. Berridge, F.Z.S.

No. 24.-ANIMALS AT THE ZOO. Sixty Photographs by the Same.

No. 15.-SOME MOTHS AND BUTTERFLIES AND THEIR EGGS. Sixty Photograph by $A$. E. Tonge, F.E.S.

No. 16.-WILD FLOWERS AT HOME. Fourth Series. By Somerville Hastings.

No. 17.--BRITISH MAMMALS. Sixty Photographs from Life, by Oxley Grabham. M.A.. T. A. Metcalfe, Sydney H. Smith, and Chas. Kirk.

Nu. 18.-POND AND STREAM LIFE. Sixty PhotoEraphs from Life, by Walford $B$. Johnson and stanley C. Johnson, M.A.

No. sg.-WILD BIRDS AT HOME. Third Series. By Chas. Kirk.

No. 20.-ALPINE PLANTS AT HOME. First Series. Sixty Photographs by Somerville Hastings, F.R.C.S. No. 21.-FOSSIL PLANTS, Sixty Photographs by E. A. Newell Arber, M.A., F.L.S., F.G.S.

No. 23.-ALPINE PLANTS AT HOME. Second Series. By Somerville Hastings.

No, 23.-OUR FLOWERING SHRUBS AND HOW TO KNOW THEM. Sixty Photographs by Chas. Kirk.

No. 24.-WILD BIRDS AT HOME. Fourth Series. Sixty Photographs by Peter Webster.

No. 25.-TOADSTOOLS AT HOME. Second Series. By Somerville Hastings.

No, 26.-WILD LIFE IN THE FALKLAND ISLANDS. Sixty Photographs from Life, by Arthur F. Cobb. B.A. No. ${ }^{27}$ W. BIRDS AT THE ZOO. Second Series. By No. 28.-ANIMALS AT THE ZOO. Second Series. By W. S. Berridge.

Others in Preparation.

pRice 6D. Net each Volume, Postage 1D. Each.

GOWANS \& GRAY, Lid., London \& Glaszow 


\section{Gowans's Colour Prints}

In Germany during the last tew years attenpts have been made by some enterprising publishers to raise the standard of artistic taste of ordinary people with little money to spend in pictures, by issuing colour prints for wall-decoration, specially painted by the best artists in the country, at very cheap prices. These attempts have been attended with great success, and many hundreds of such prints can now be had. Messrs. Gowans \& Gray have gone a step further still, and they have now issued the first three of a similar specially-painted series of pictures, $14^{\prime \prime} \times 10^{\prime \prime}$ in size, which are sold in neat brown or white paper frames, ready to hang on the wall, at the unprecedented price of One Shilling each; post free, I/4.

THE TITLES OF THE THREE 1SSUED ARENo x. "MY poOr DOG Tray," by Charles Pears. No. 2. "APPLE BLOSSOM," hy JeSSIE M. KING. No. 3. "FAR FROM THE MADDING CROWD," By Stephen Reid.

They are all artistic enough to hang in any roon, no matter how luxurious, and should supersede those oil-colour daubs and grocer's-calendar-pictures, which are so often to be seen hung up in British houses, where everything else, except the pictures, is in good taste.

Gowans \&e Gray, Lttd., London and Glasgow 
Gowns's Naturl: Books, No. 29

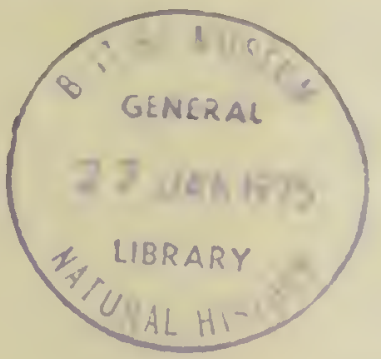

Wild Birdes at Home

FIFTH SERIES

ROBERT MACLEHOSE \& CO. LIRITEO, PRINTERS, GLASGOW

BLOCKS BY HSLOP A DAY. EOINBURGM

PAPER BY ALEX COWAN SONS, LIMUTEO. EOINCURGH 


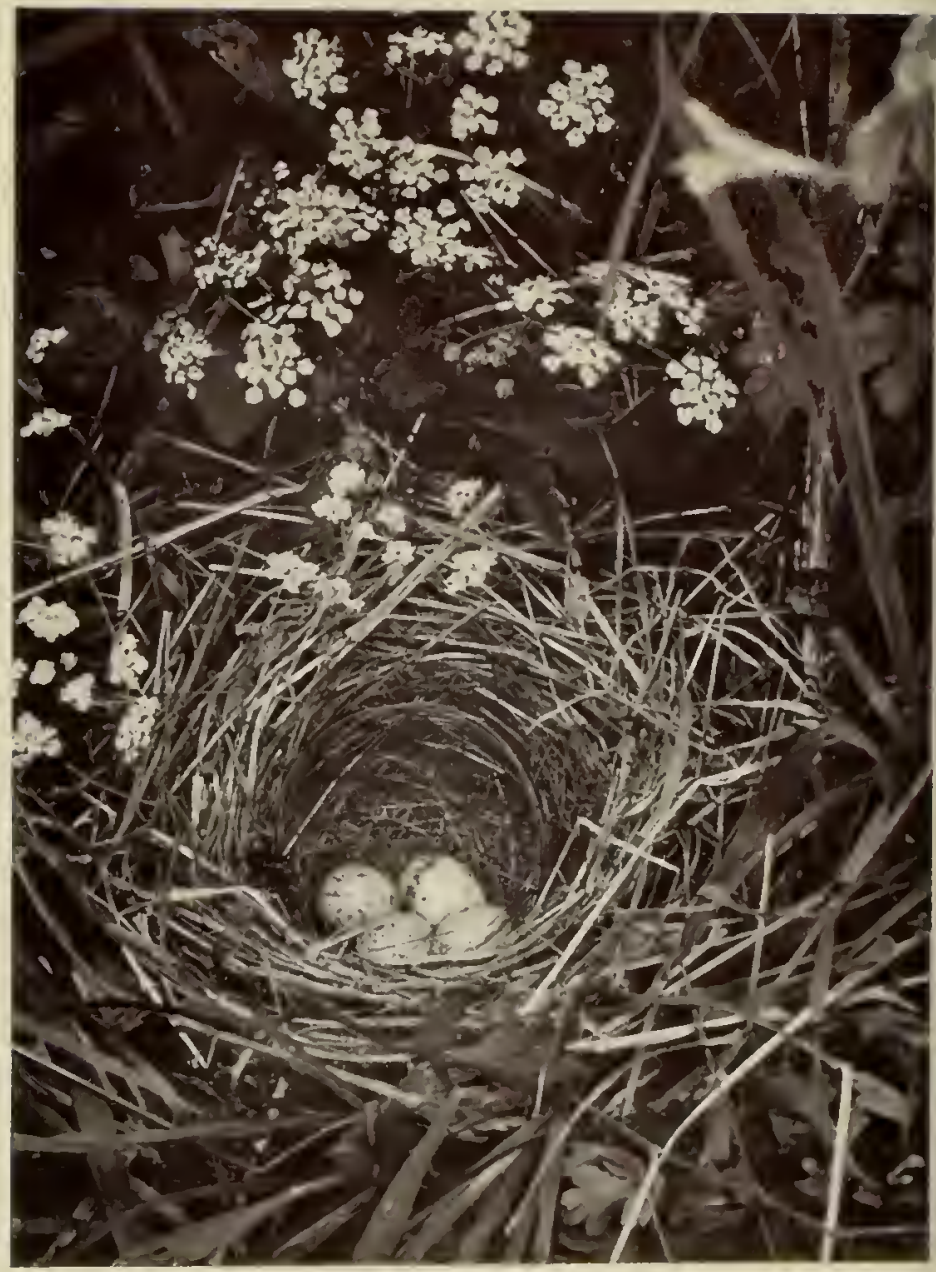

NIST ANI Eggs or WHITITIROAT

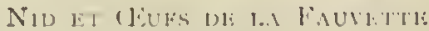

(iinst 1")

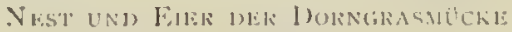




\section{WILD BIDDS}

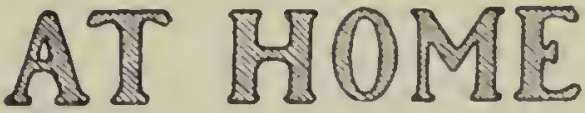

$$
\text { FIFTI SIRIES }
$$

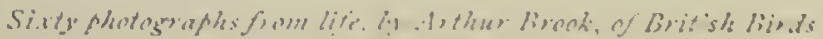
abititeil atoss

GOIIAS \& CRAI: IAH.

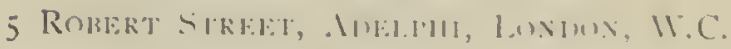

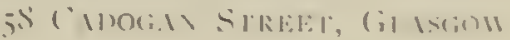



M AN bof the photograths in this stolume sivill be a revelation to bird levers and nature-photosmphers. Sollings liner has bien done thesn the servis of photergath

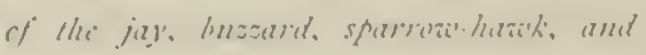
kestrel which, with wher fint smipshots.

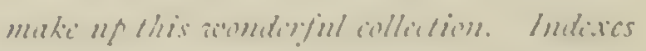
to the lingtish and l atin mames of the hivds

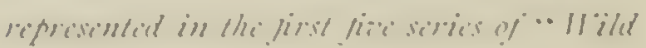
liveds of llome" witl bi finnd at the end

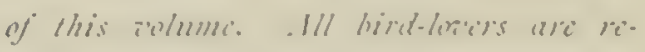
ylusted to complete thite sets be furchasing snith iolumes as they de net alriatly possiss.

Finlargements ant lantern-stide: of the photographs in this book may be lo.tu of Mr. Millur lirook, Wyeburn Iluuse, Builh IIells, Breconshire. 


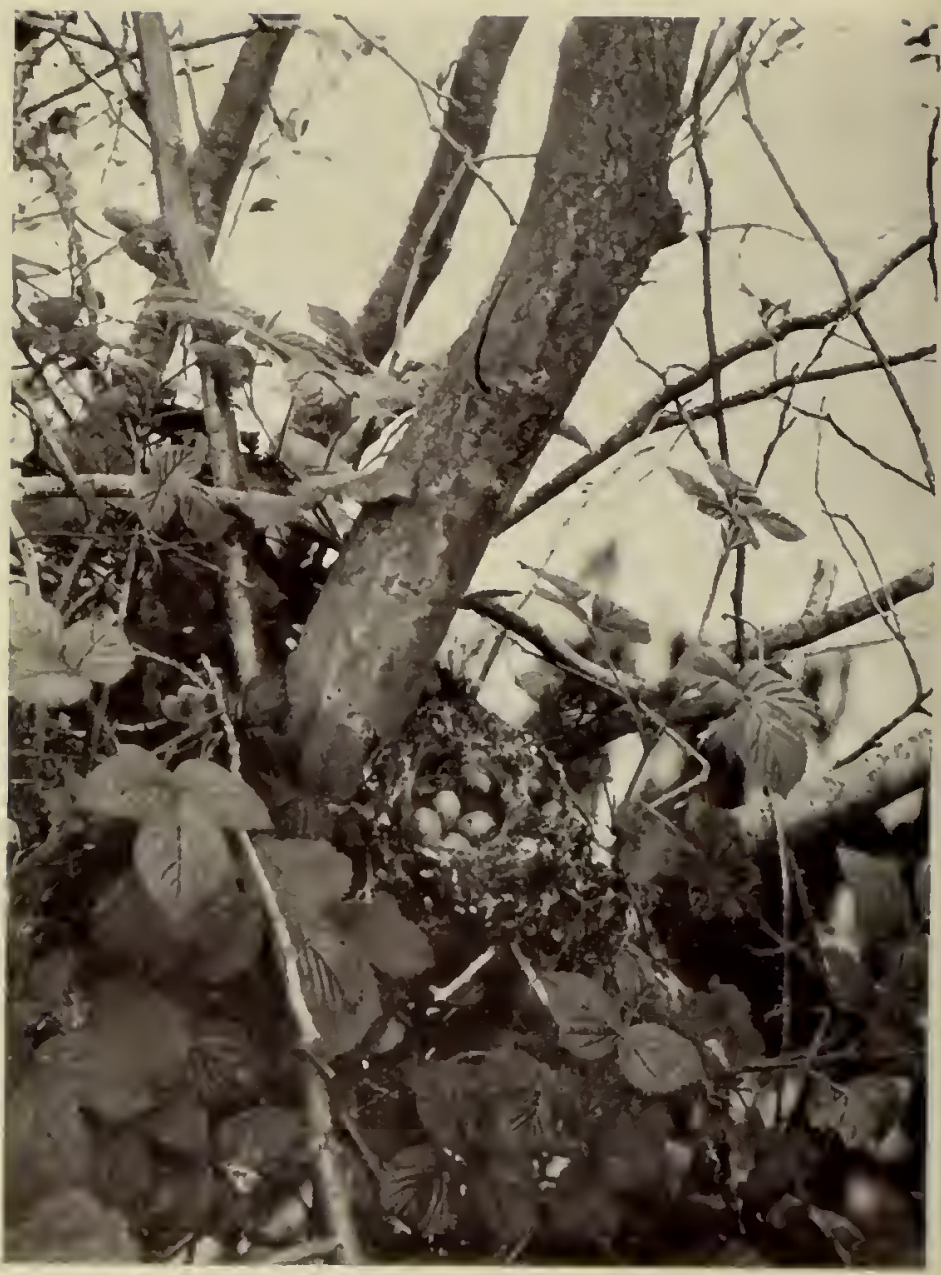

Niesr and EgGs of CHAFFINCH
Nin el (liurs nu binson OKDIXAIRL

NEST UND EIER DES BUCHFINKAN 


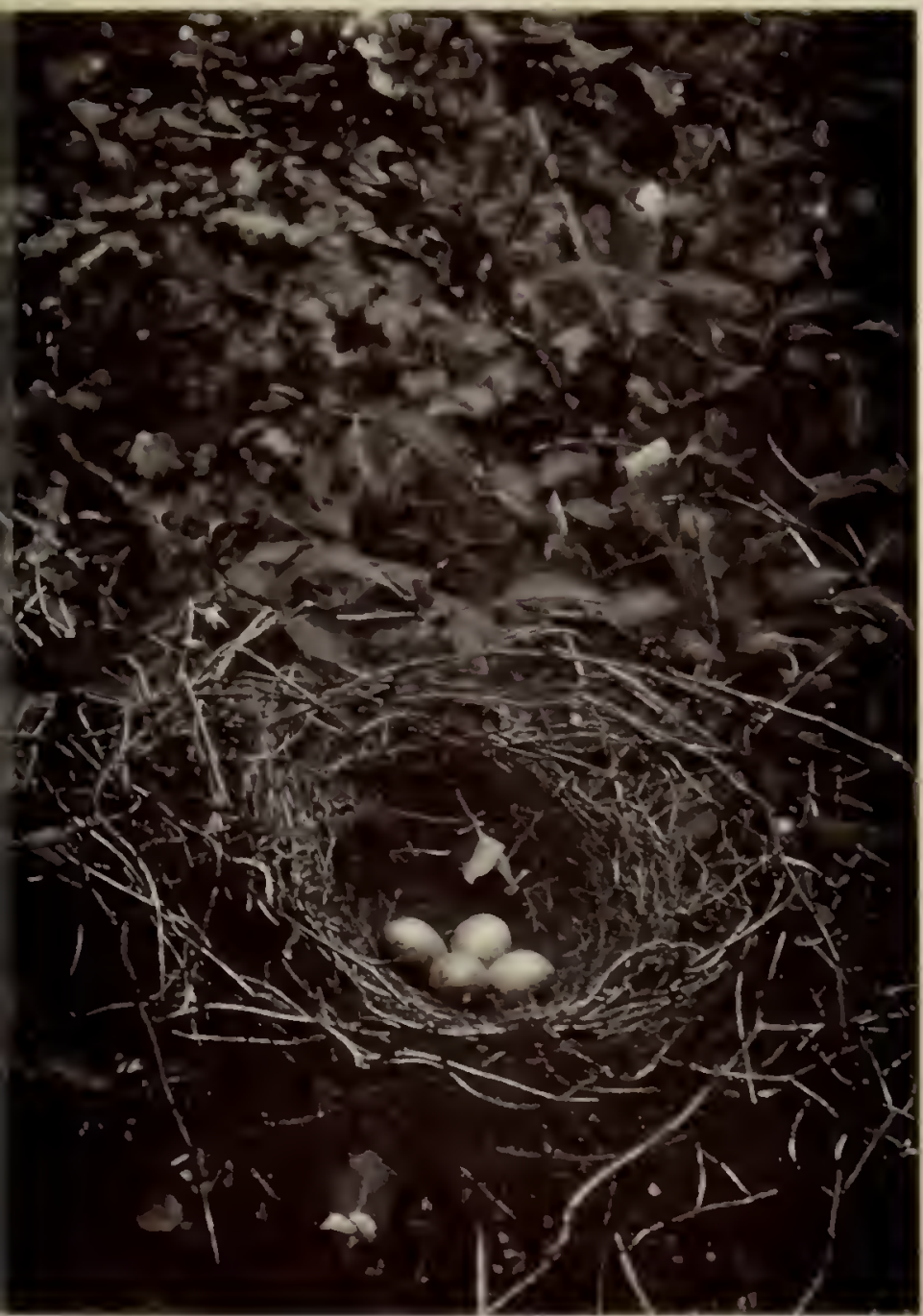

NLST AND Eisis OF JAY Nin ET (FUES DL Ge.M Nest CND bier des Eicheqhamers 


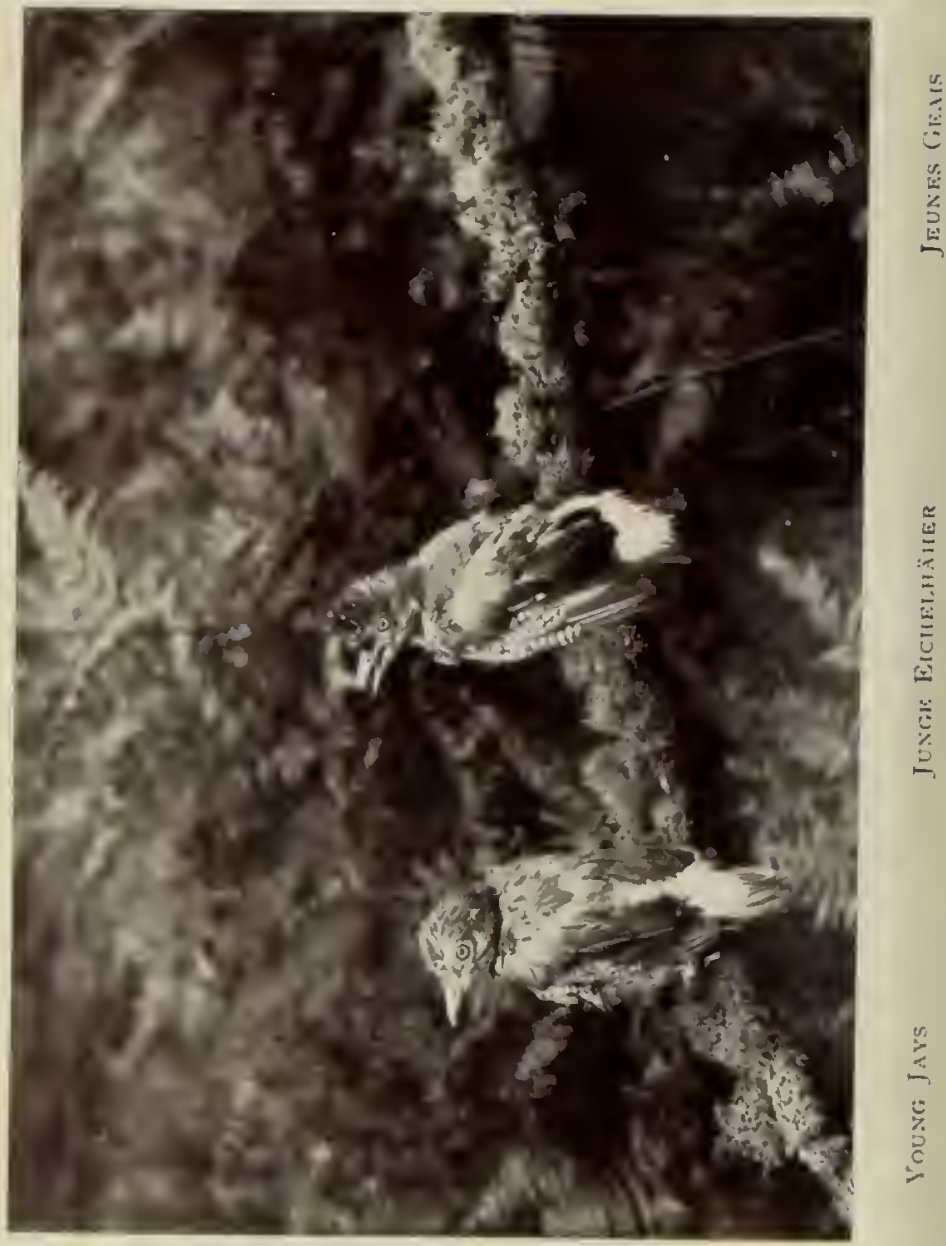




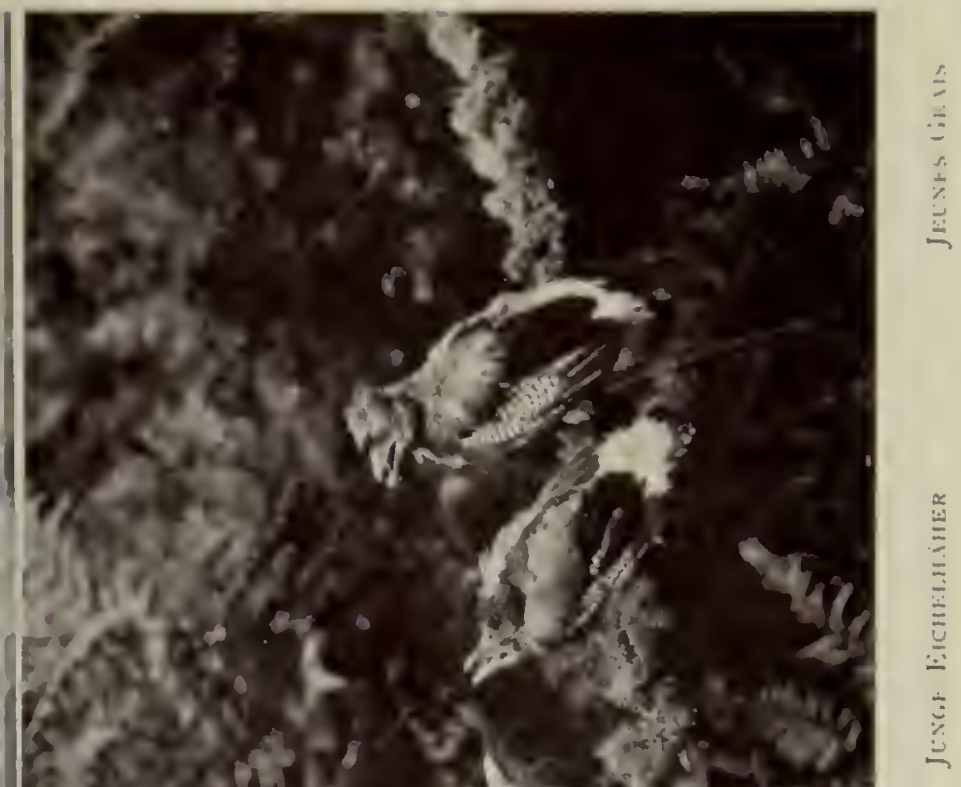




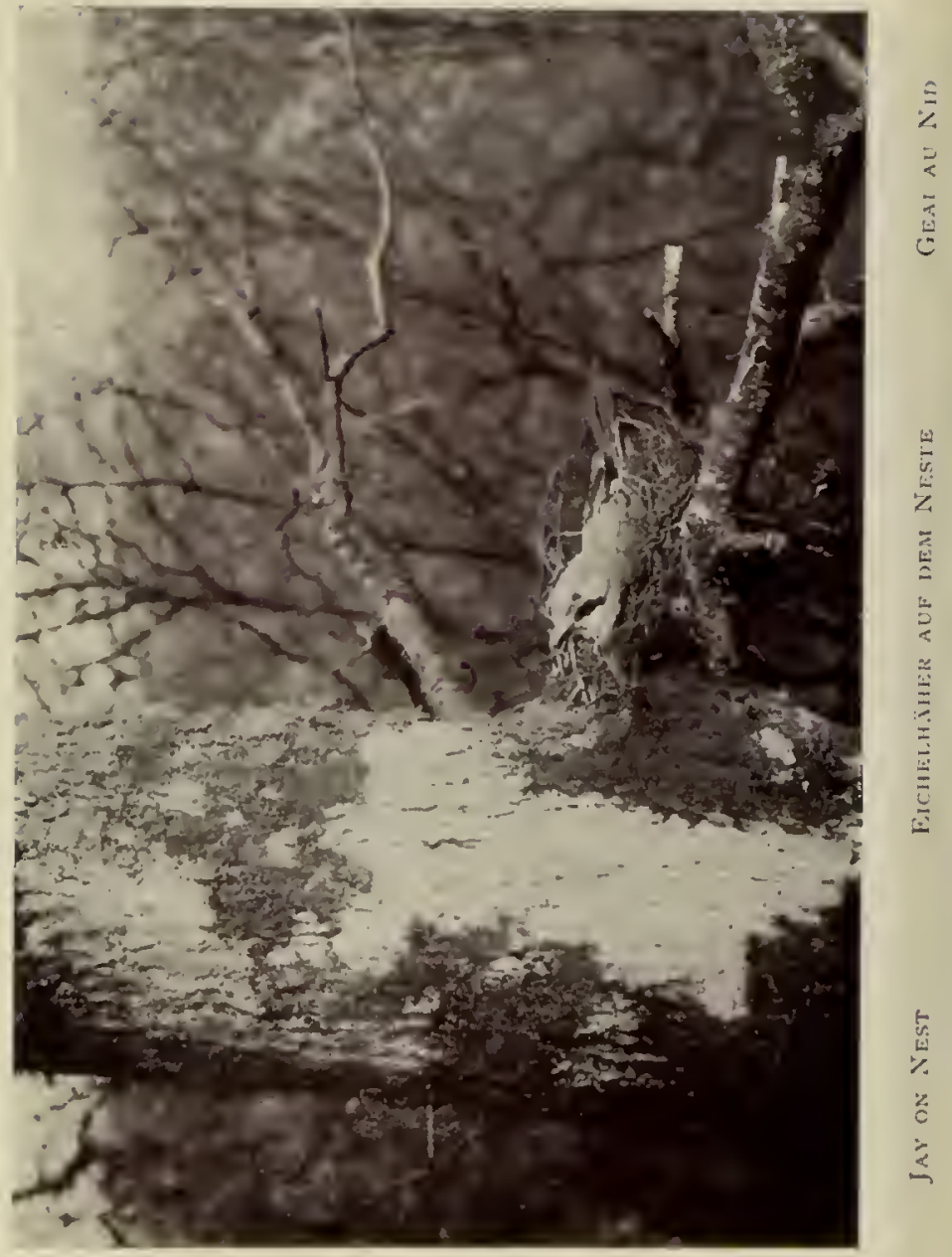




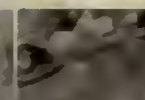

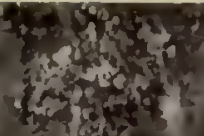

(3)

$\lim _{-2}$

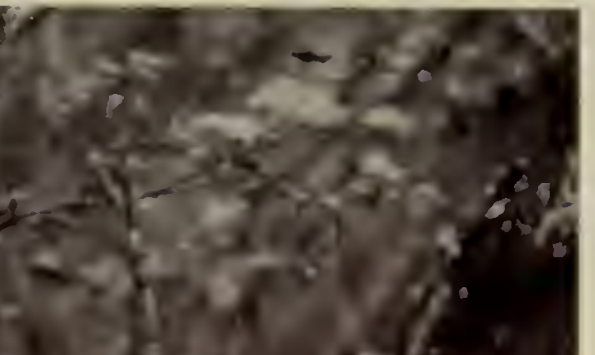

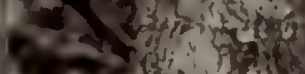

ats

s.me tat

Sermaty $x^{2}+1 \times x^{2}, 2$ $\cos ^{2} \mathrm{x}+\mathrm{sin}$

ist 1$)^{2}$

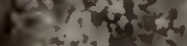

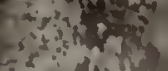

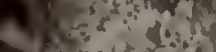

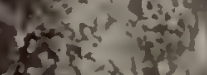
$423^{2}+13$

tel intion

$y$ re
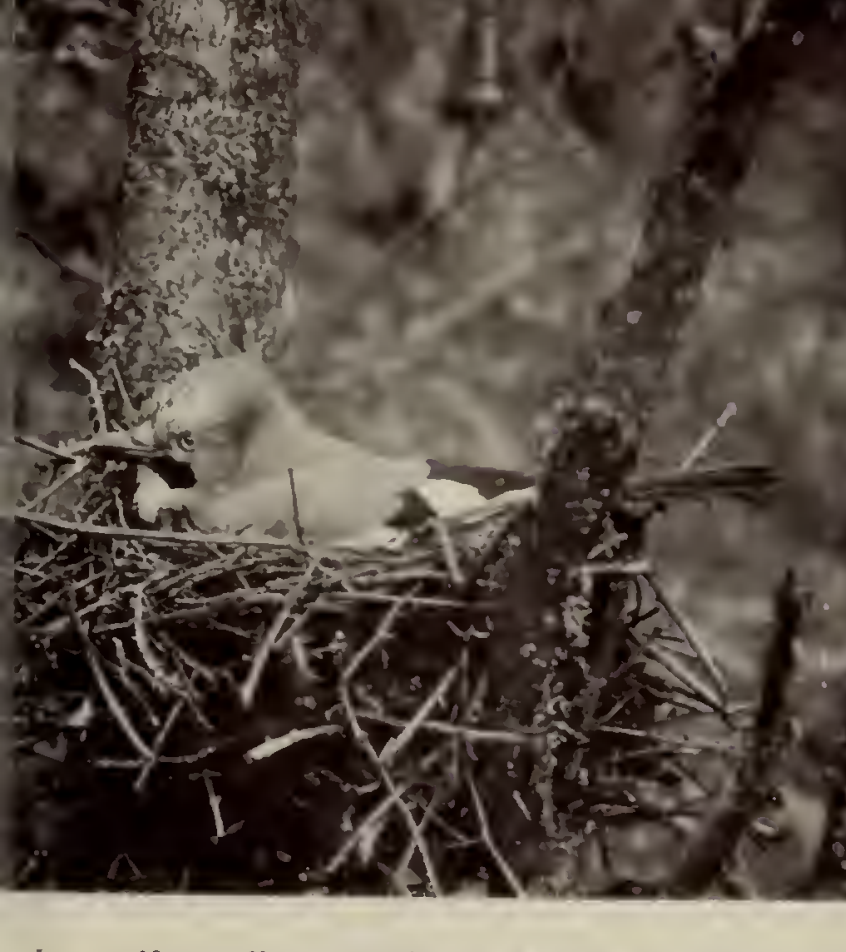

is
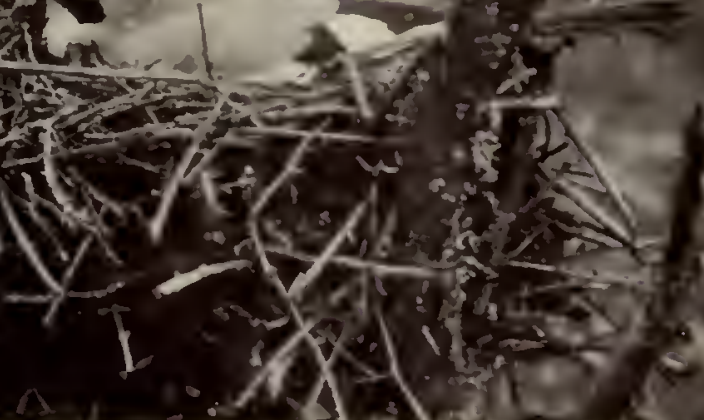

- A X

1

is $x^{2}=2$ 71
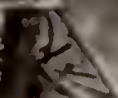


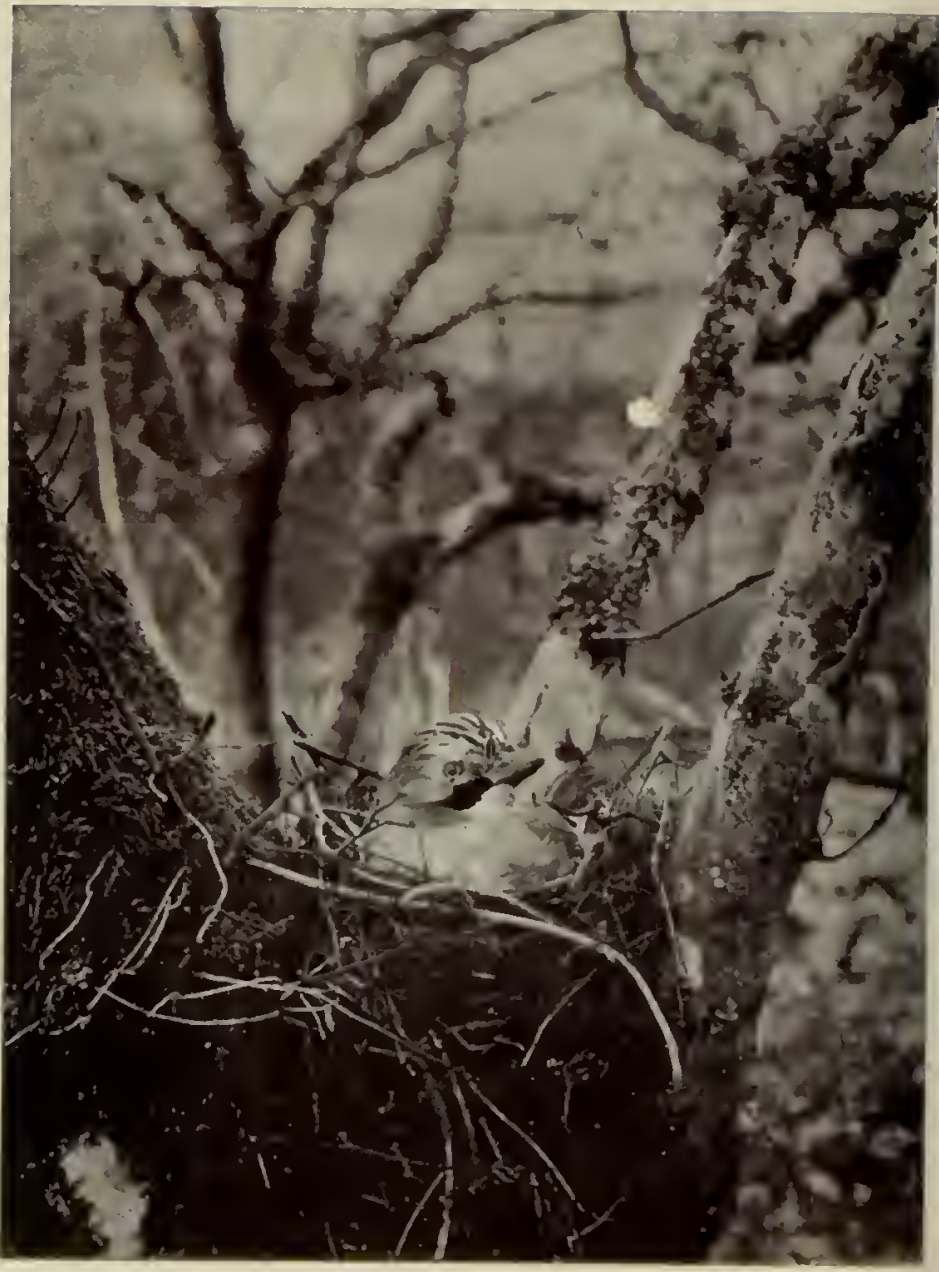

JaY on Nest Eichelhäliek aur dea Neste Geal aU Niv 


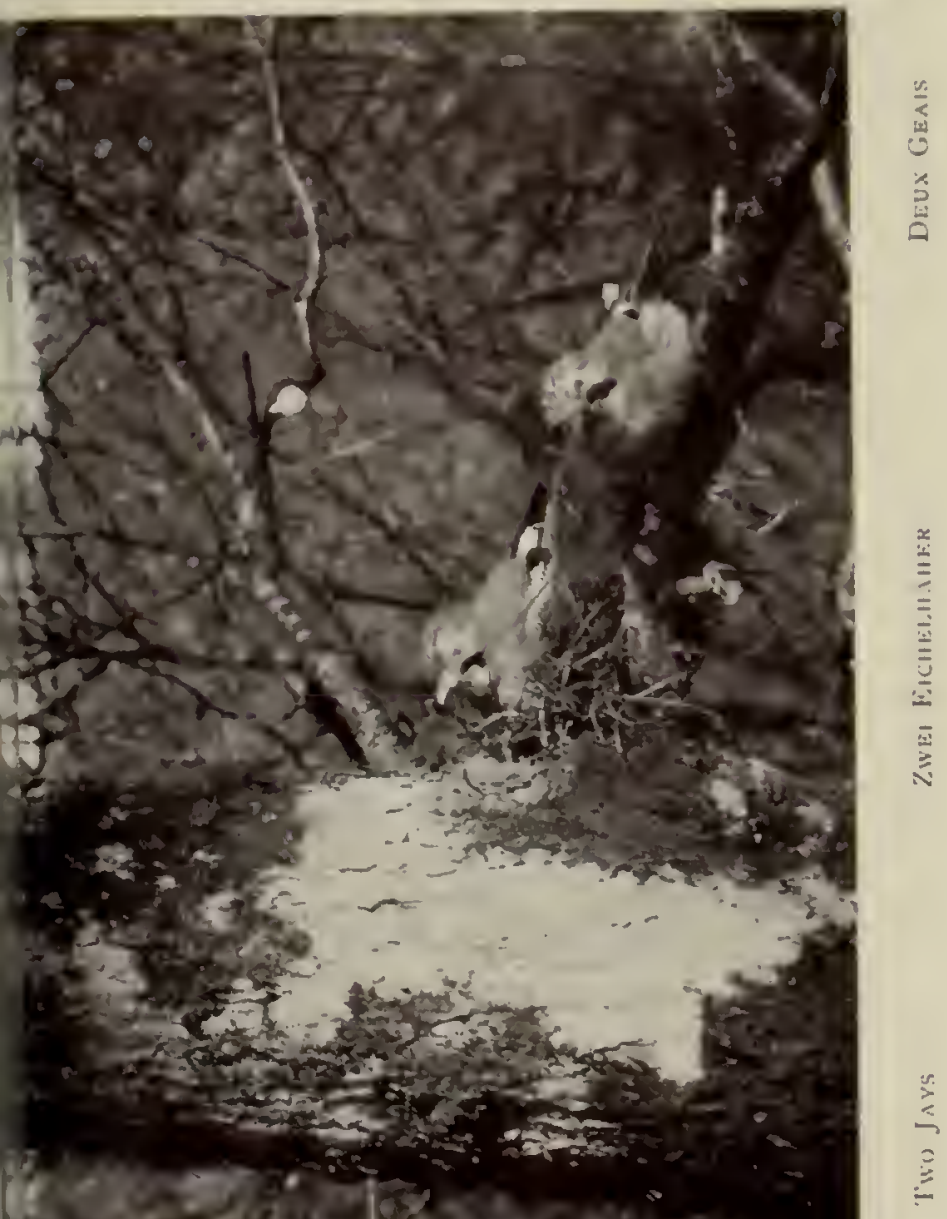




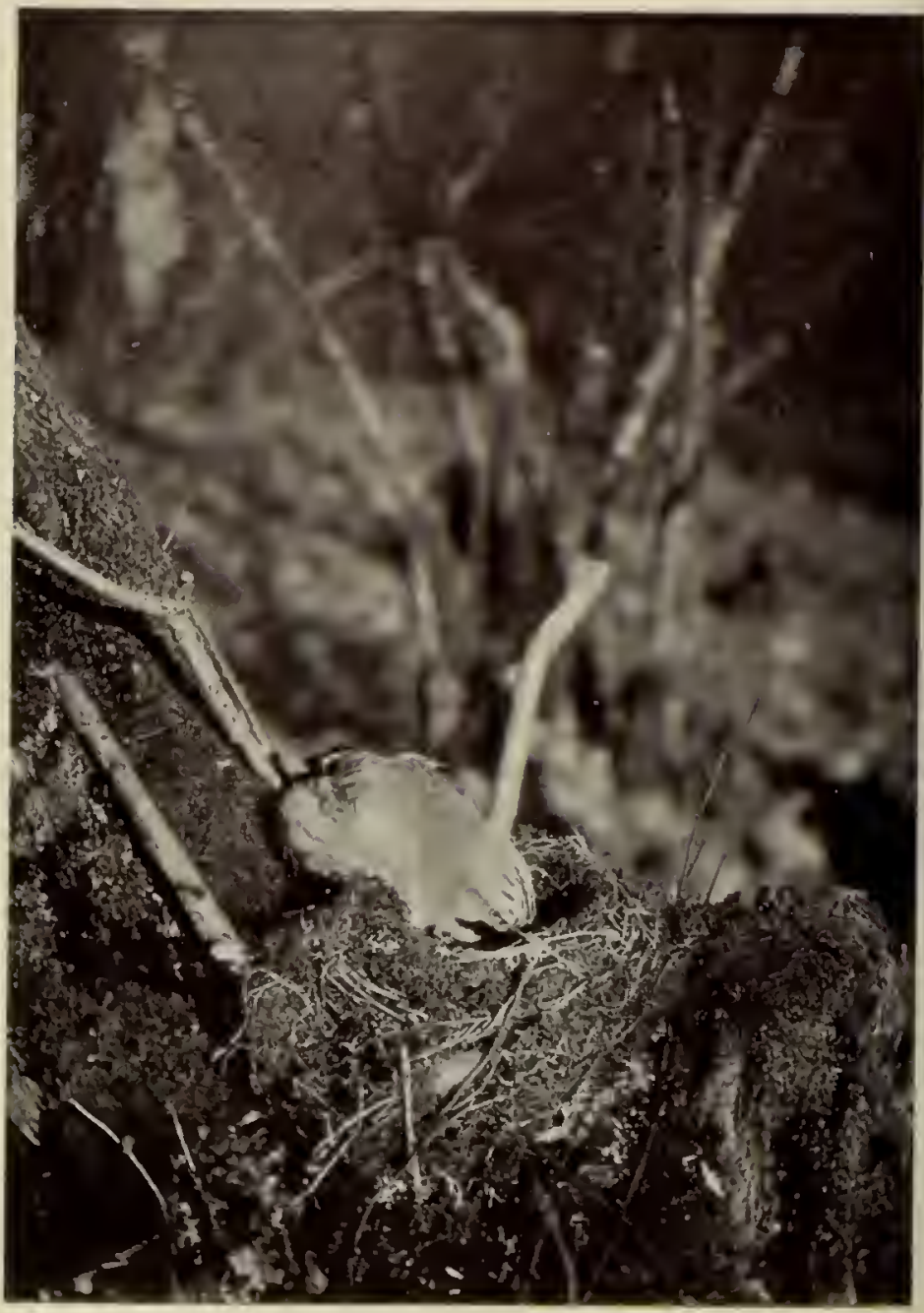

JAY SUCKING; ERegs of

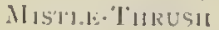

GEA sUçAN Les (lines JUN M. RI.A: DRAINL:

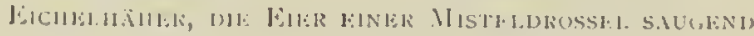




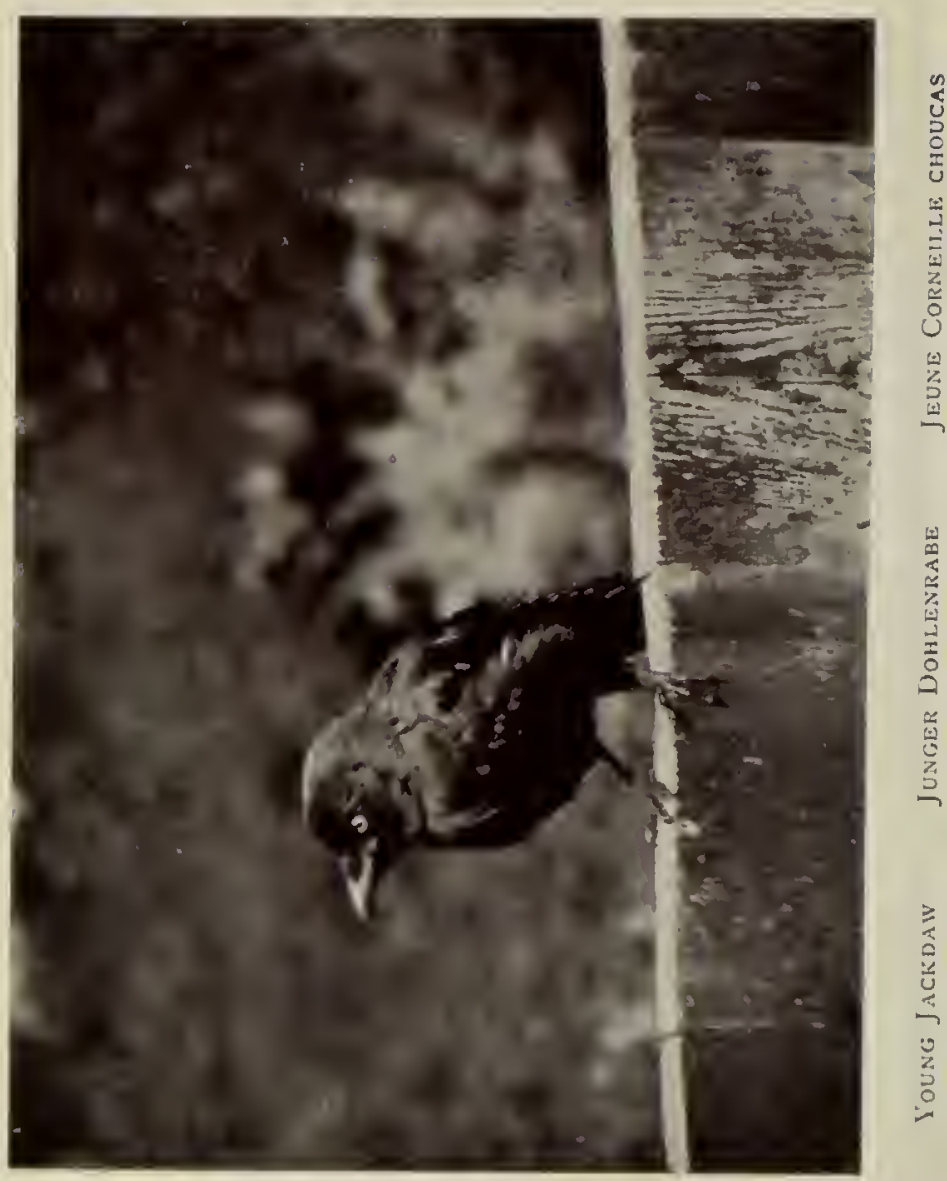




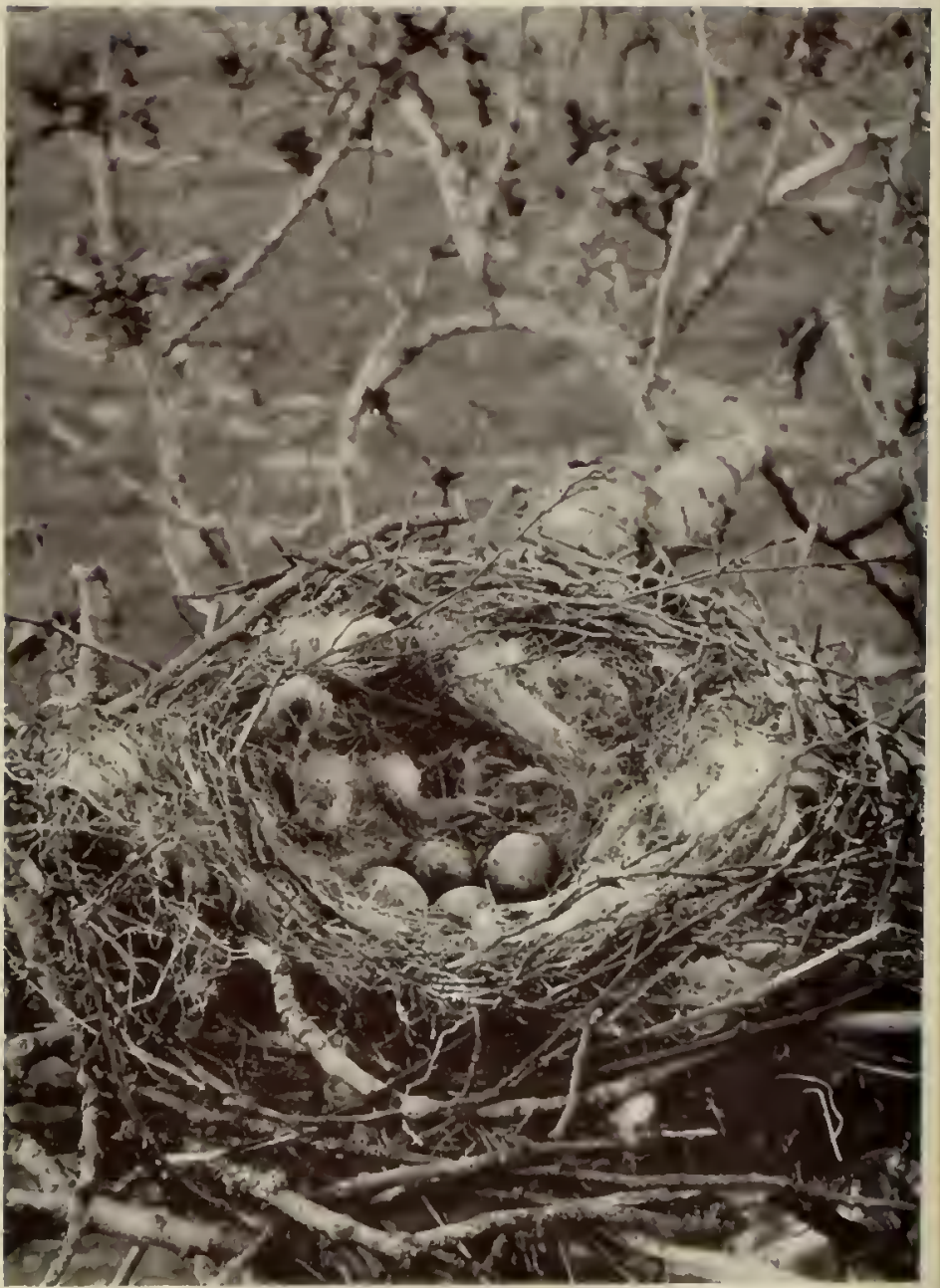

Nrst and Focis ()

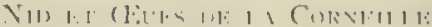

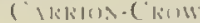
Ni)lle:

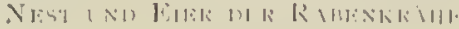




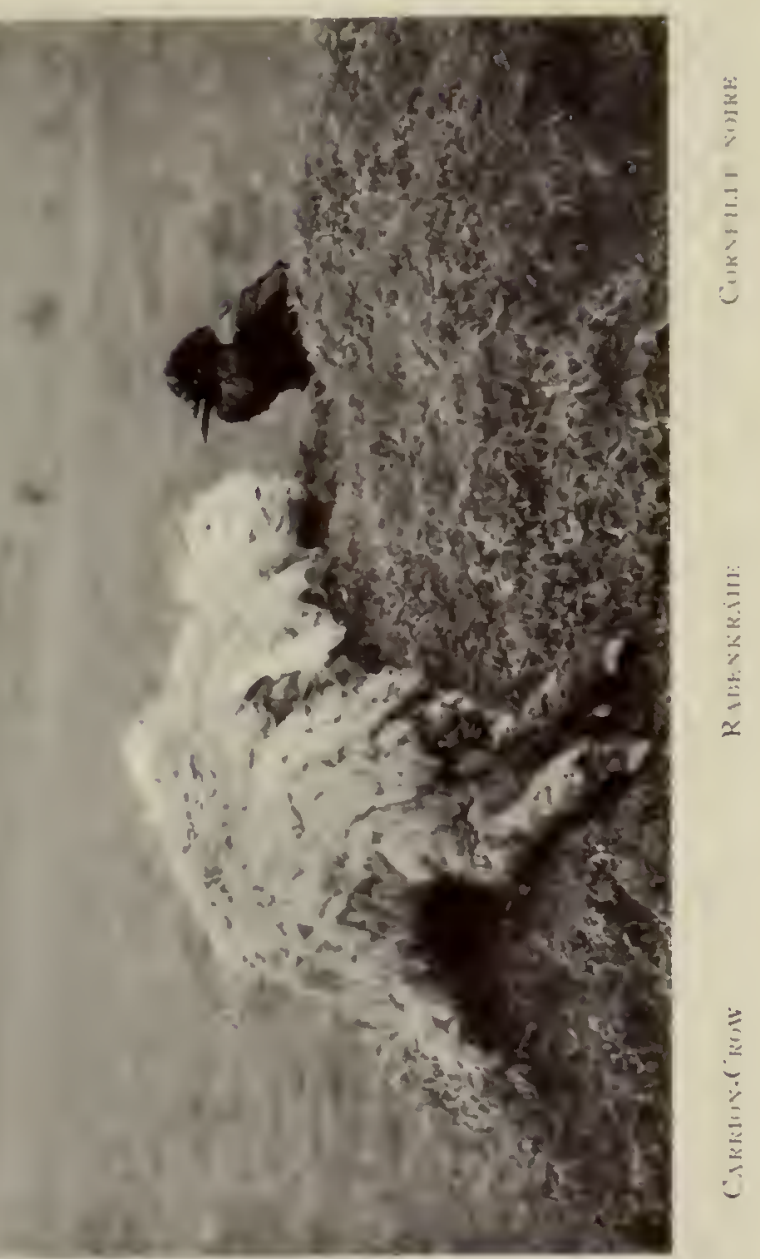




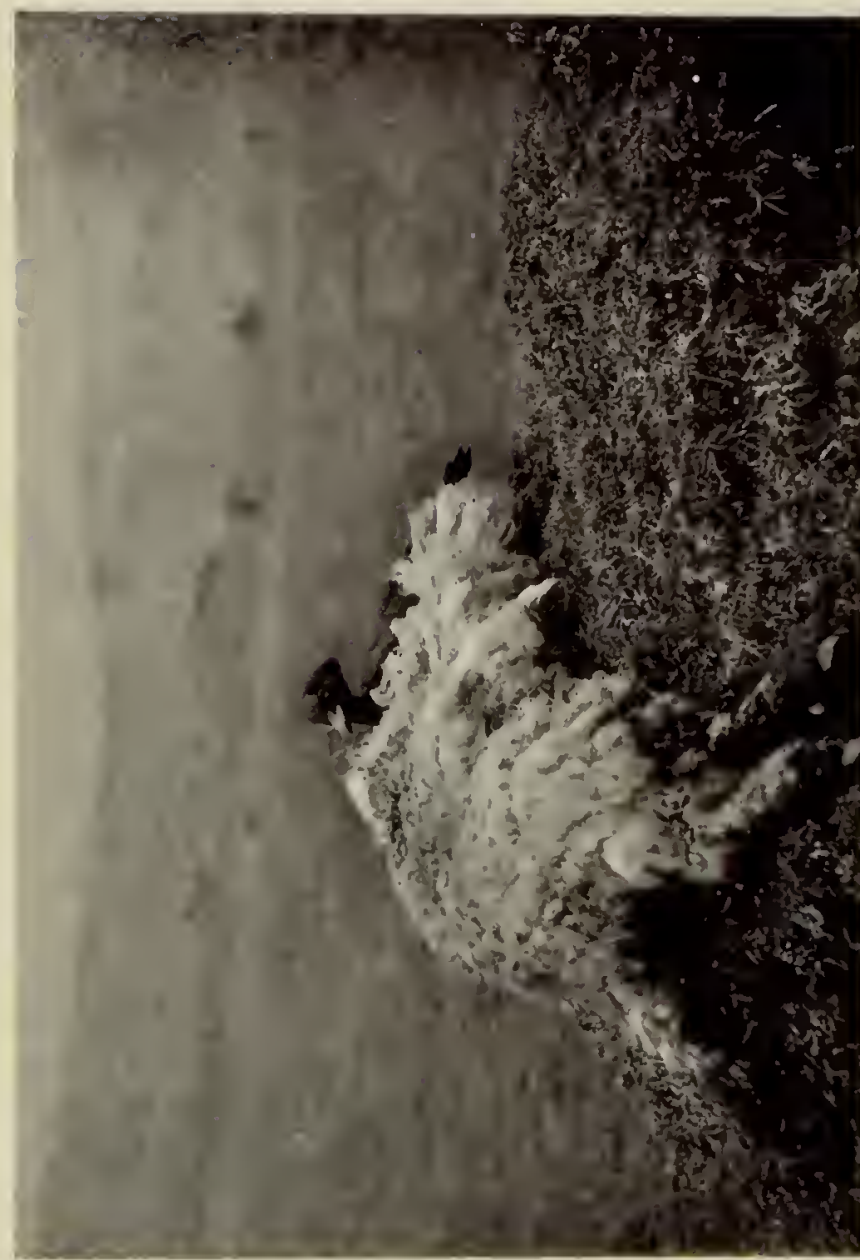




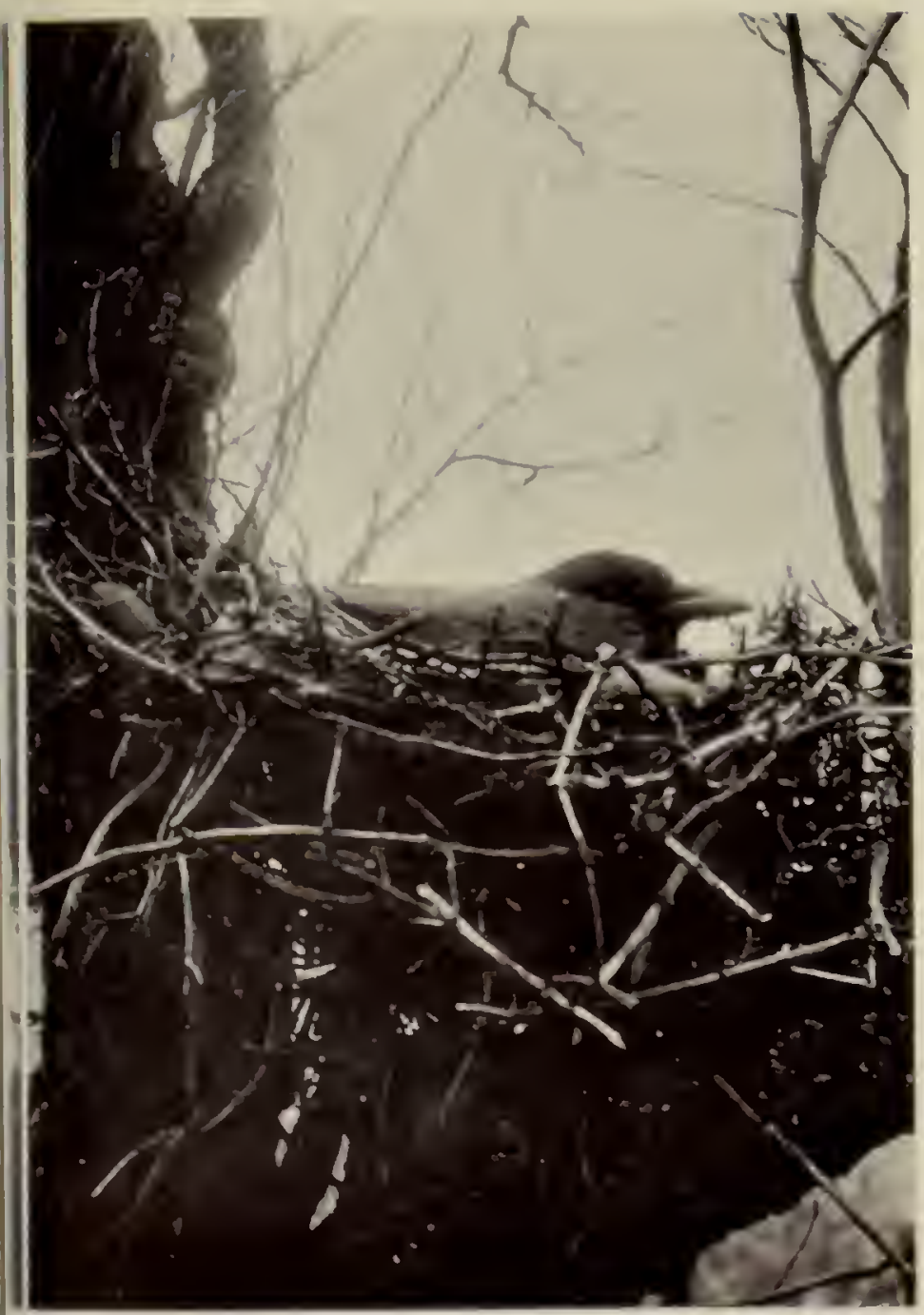

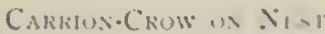

CURרFILR SURE AL SIU

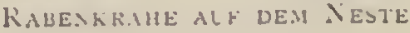




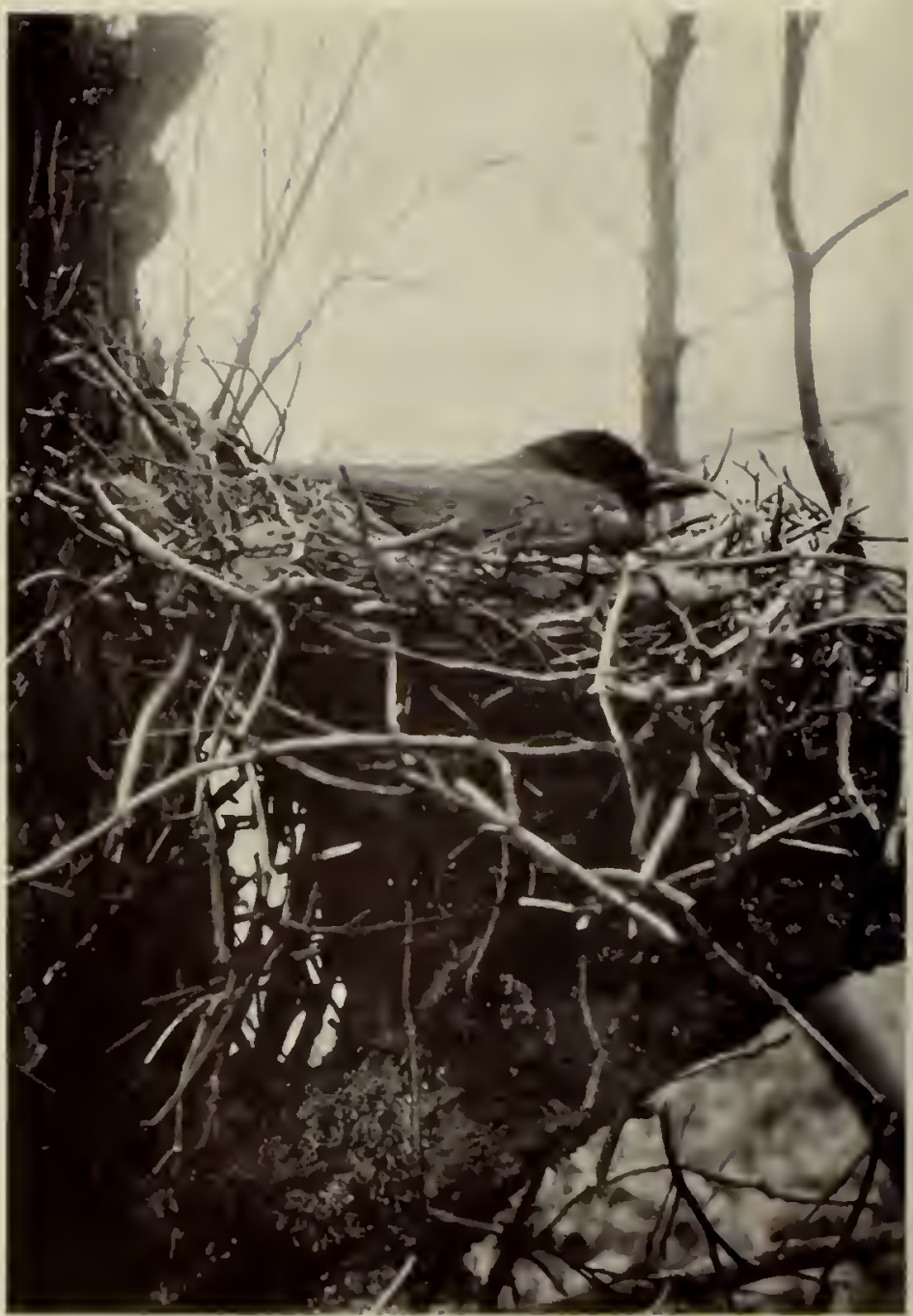

Caklifun-Chom un NBil

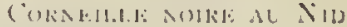

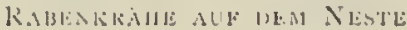




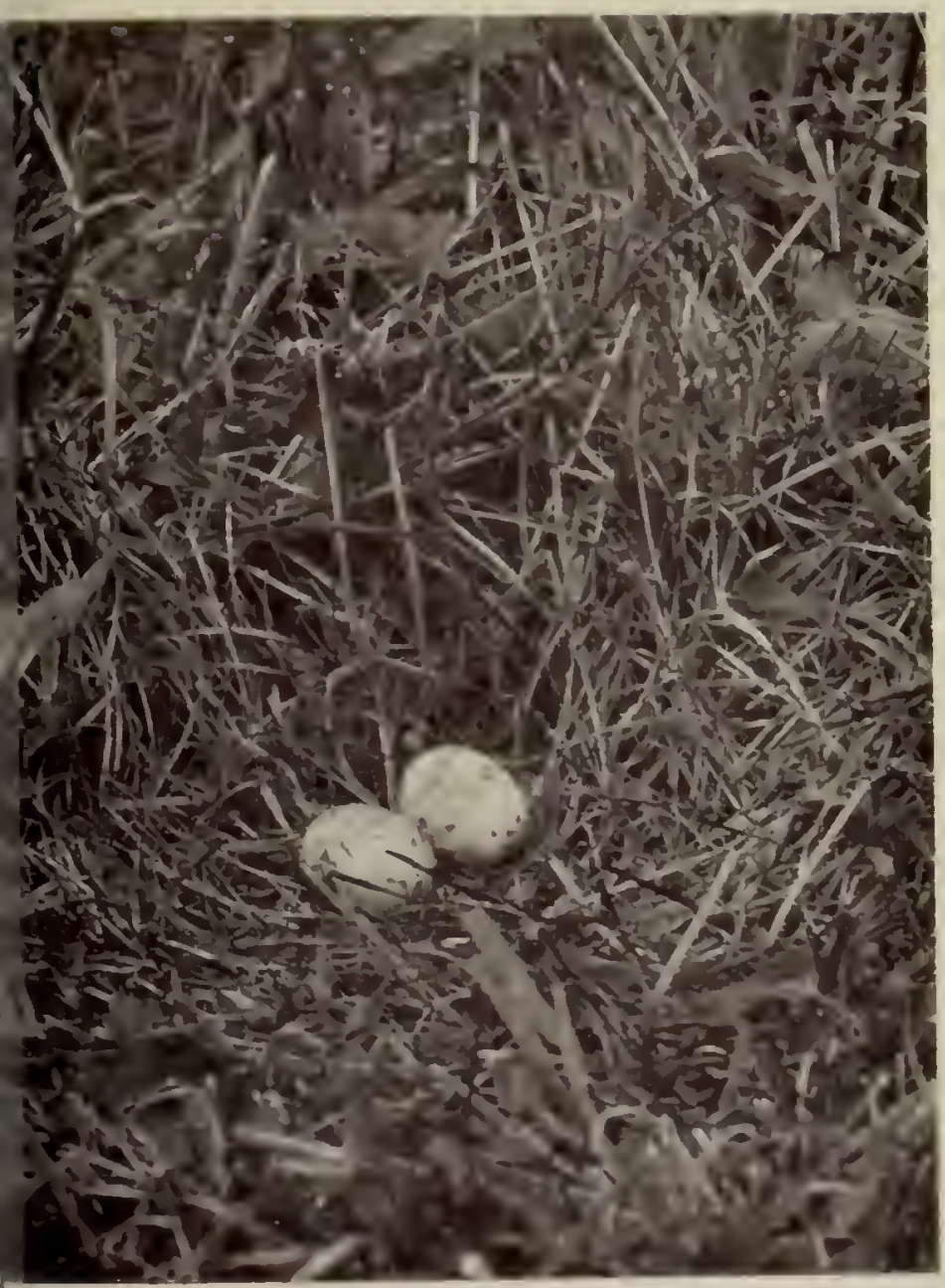

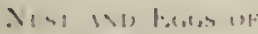
Nith J J
Num L ( 1) Fin ket

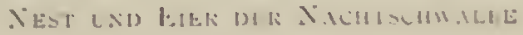




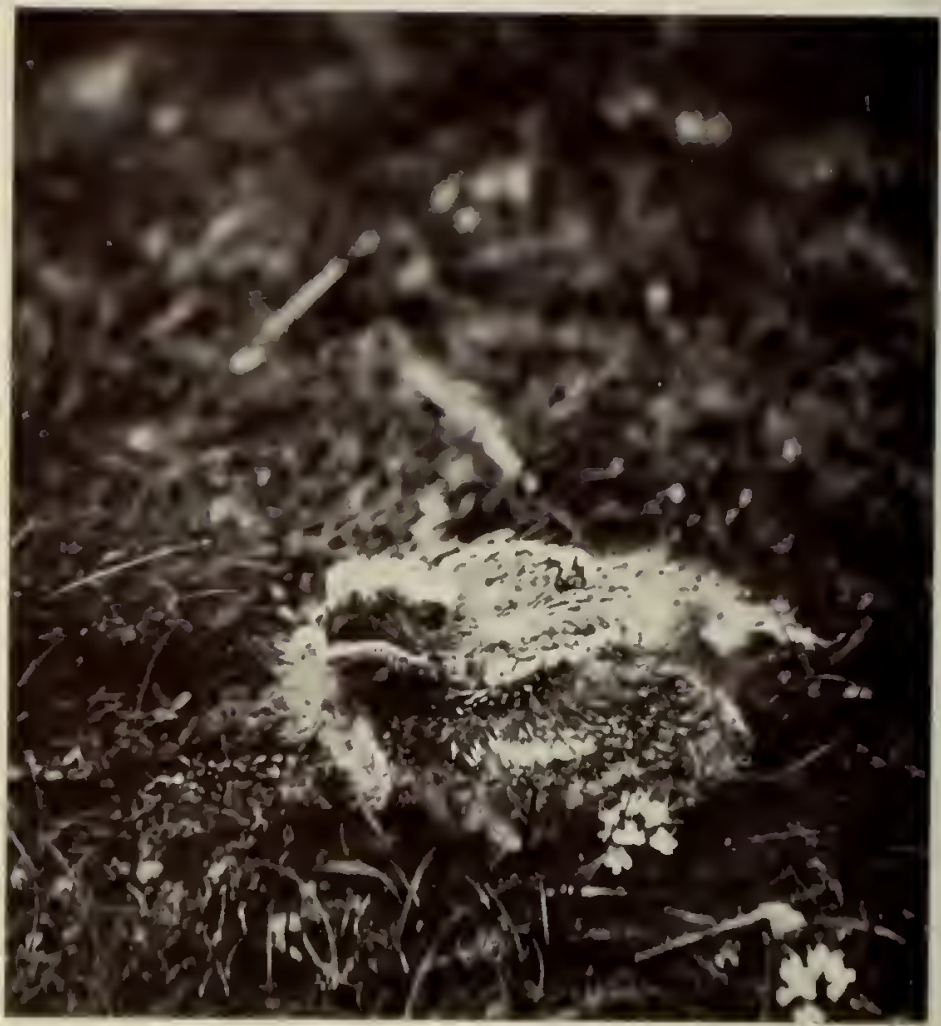

Younc: N゙LHT]а

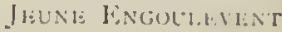
JUNGE N.ACHTSCHADAL 


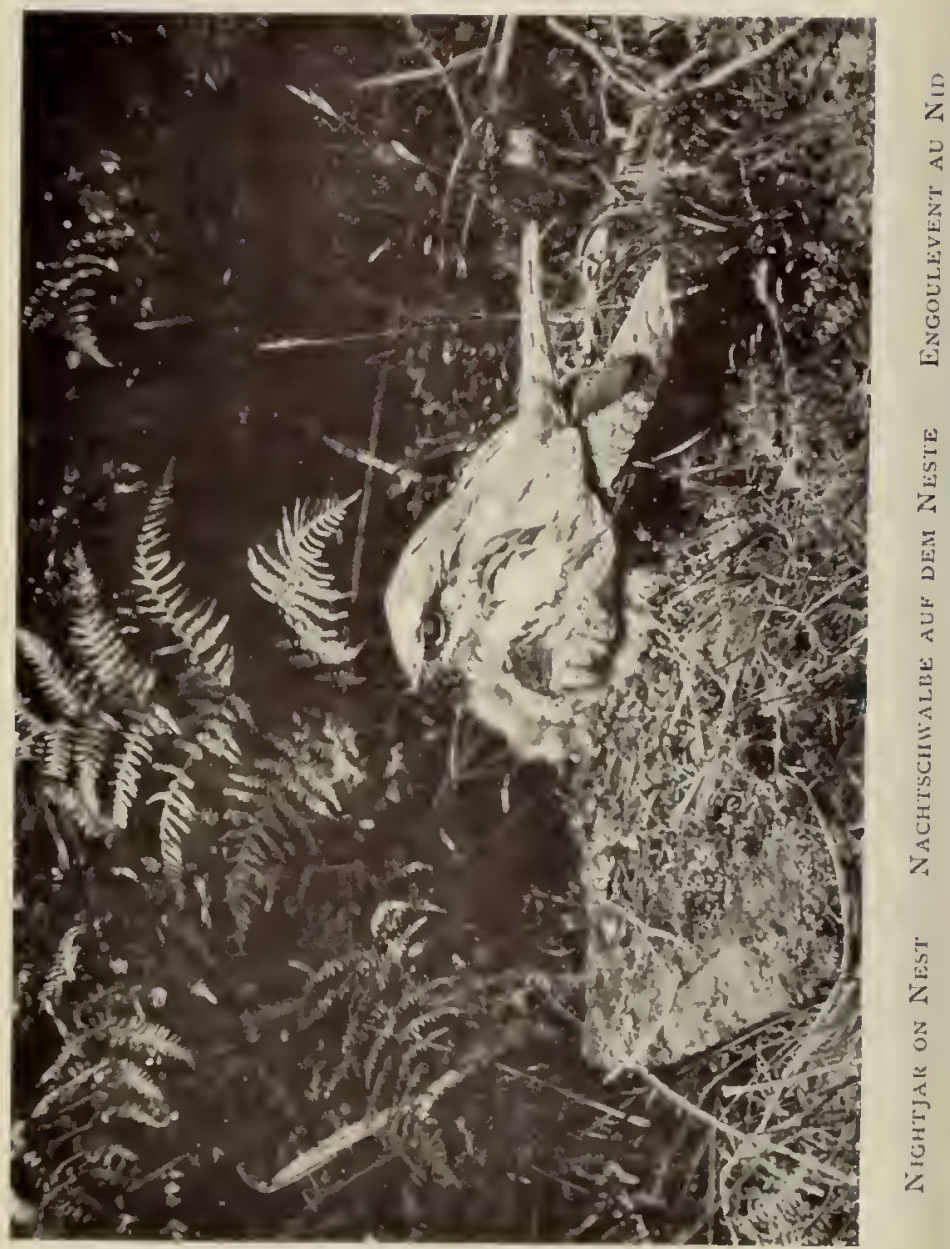




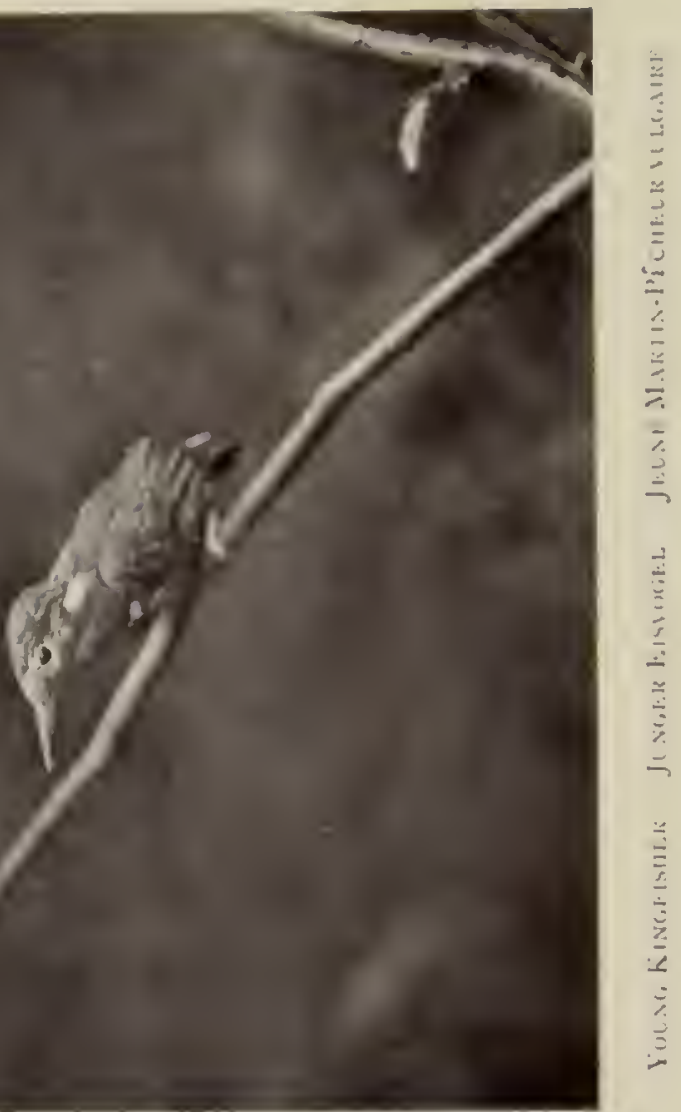




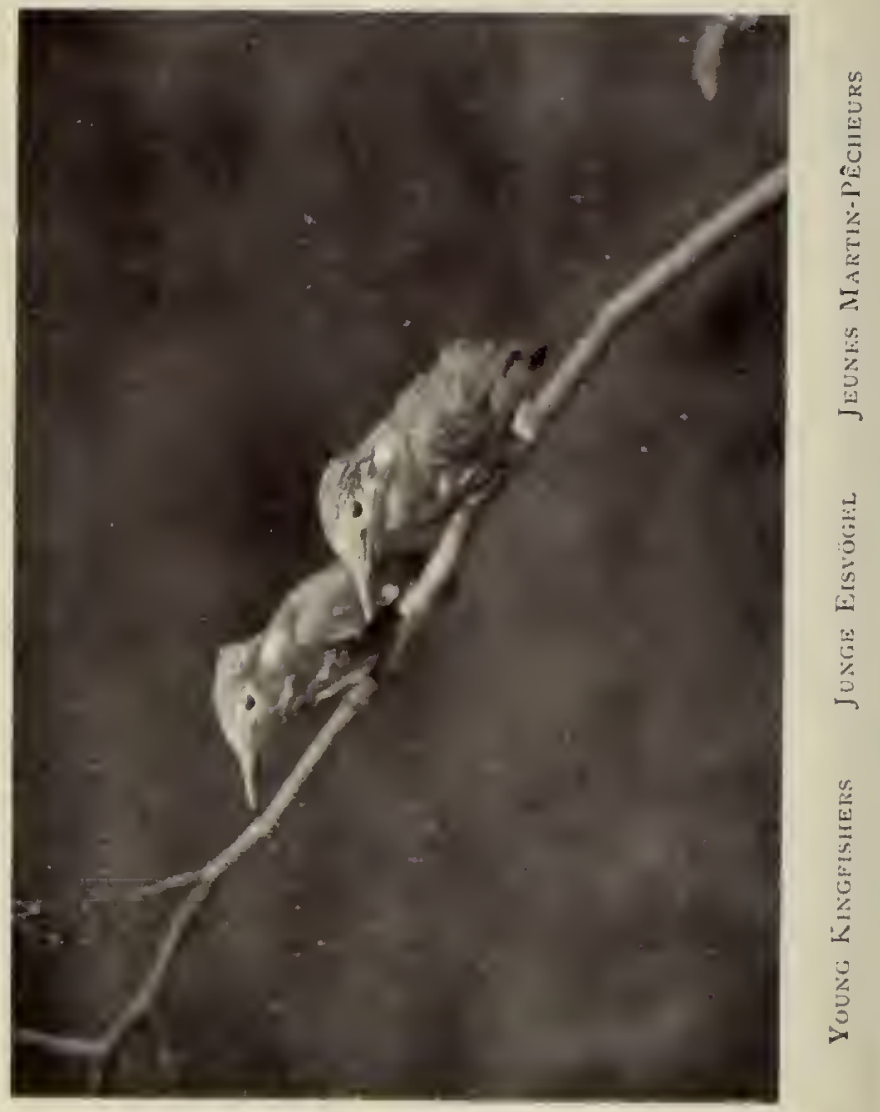




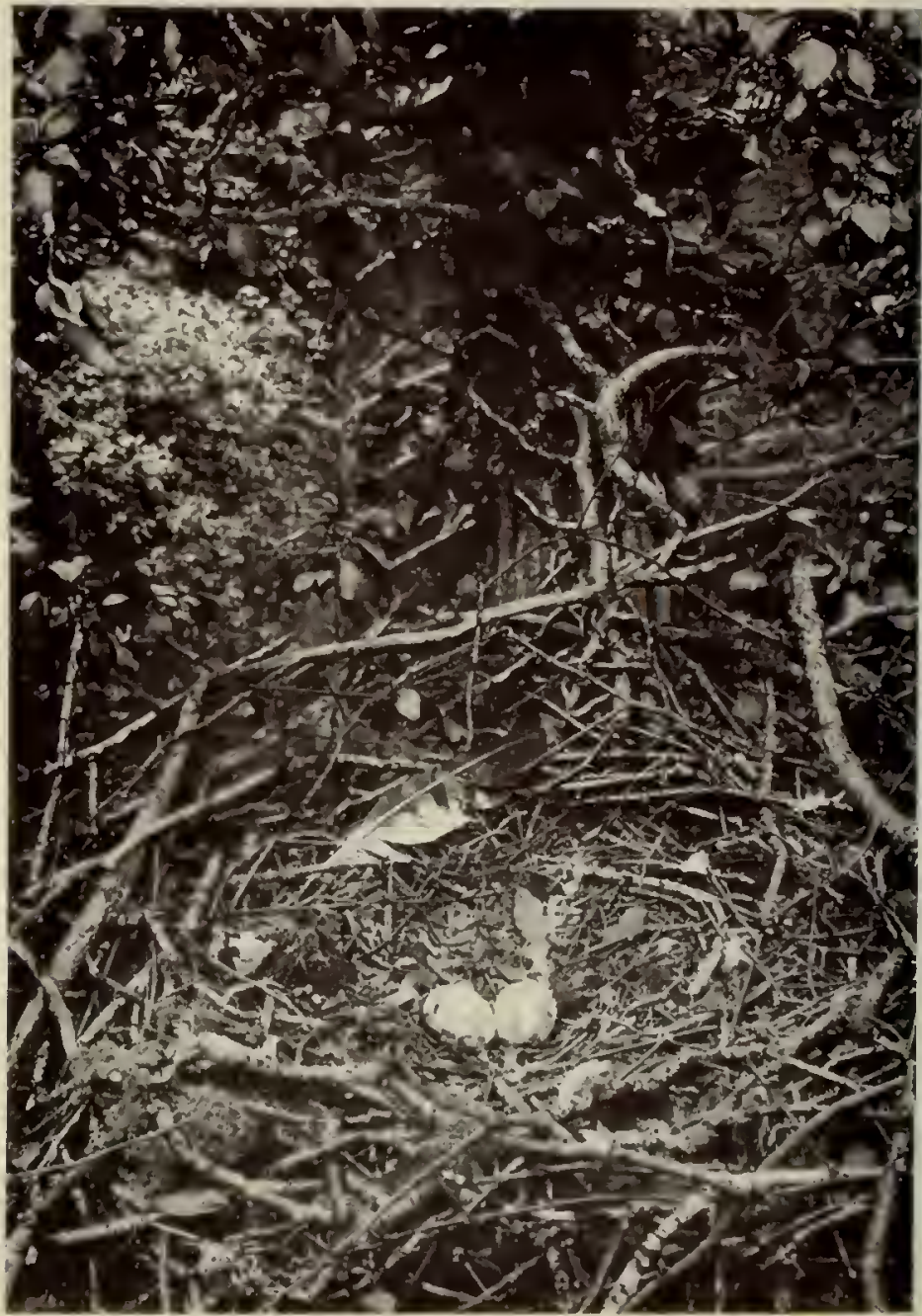

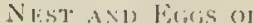

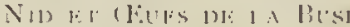
VIVIRI

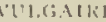

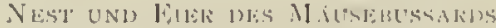




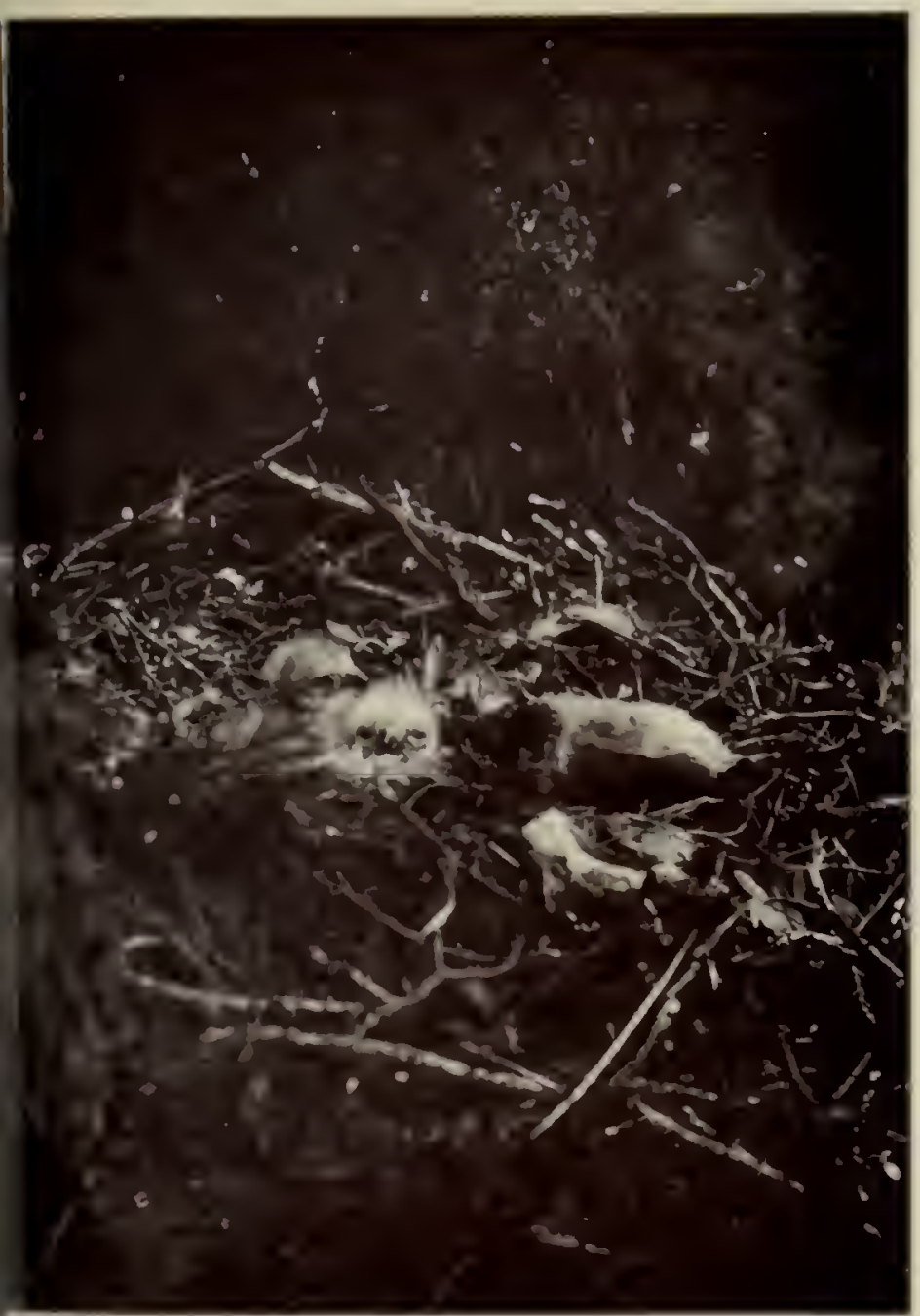

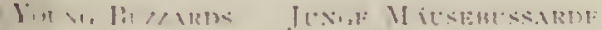

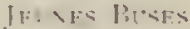

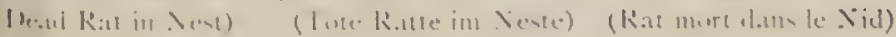




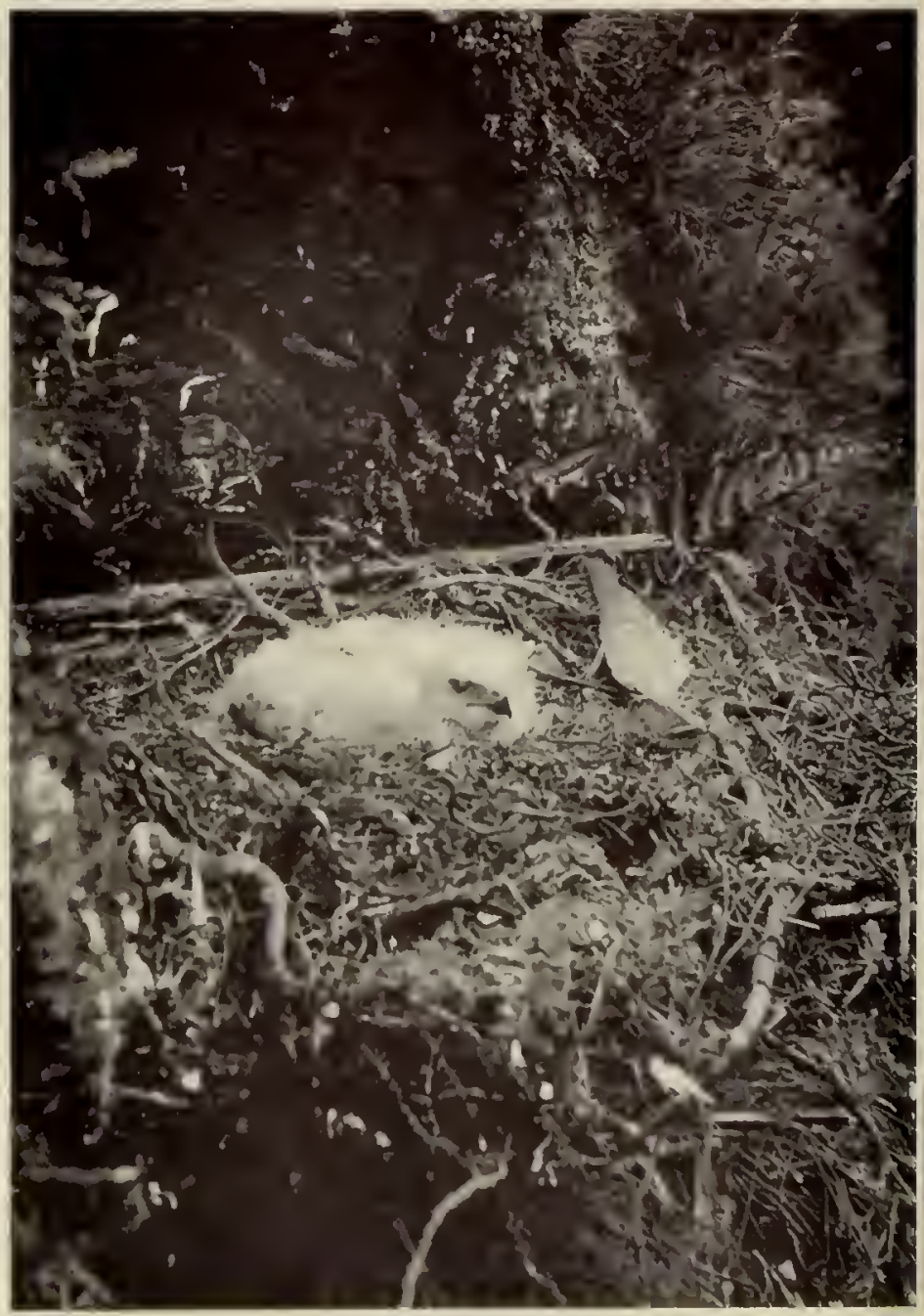

Joung liUz\%aki) IN NIESP

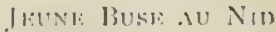
JUNGER MAUStBBUSSART tM NI:STH. 


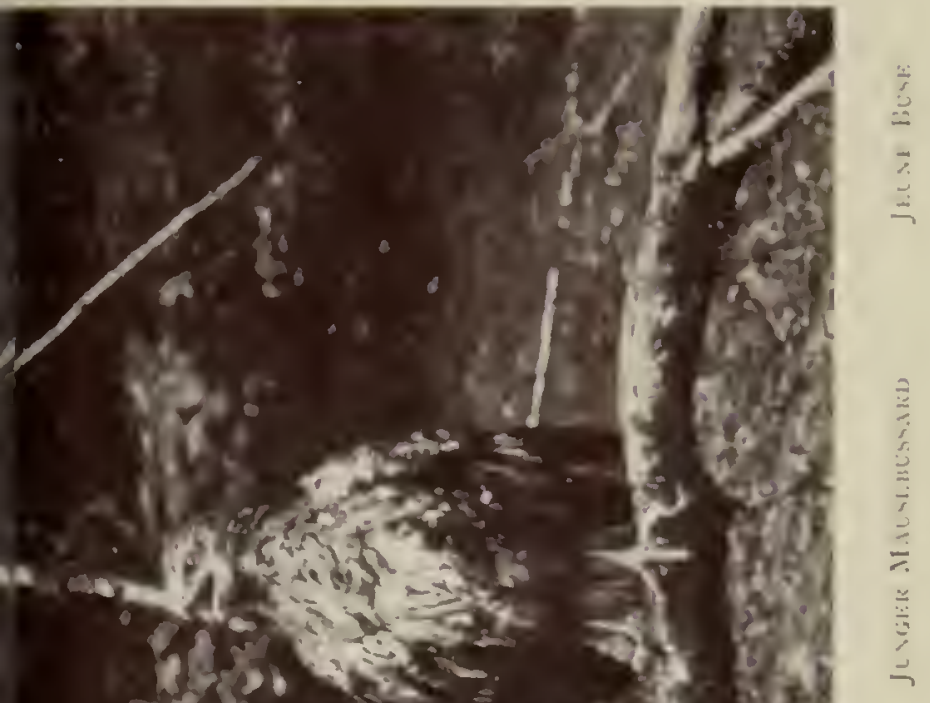

(3)

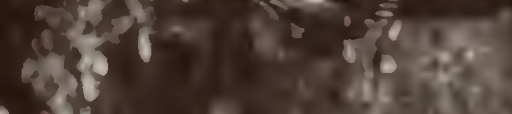

, Q if 80

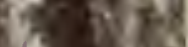

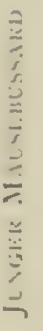
? $:-13,1,2$ a.t. bit? 11.8. i. 6 


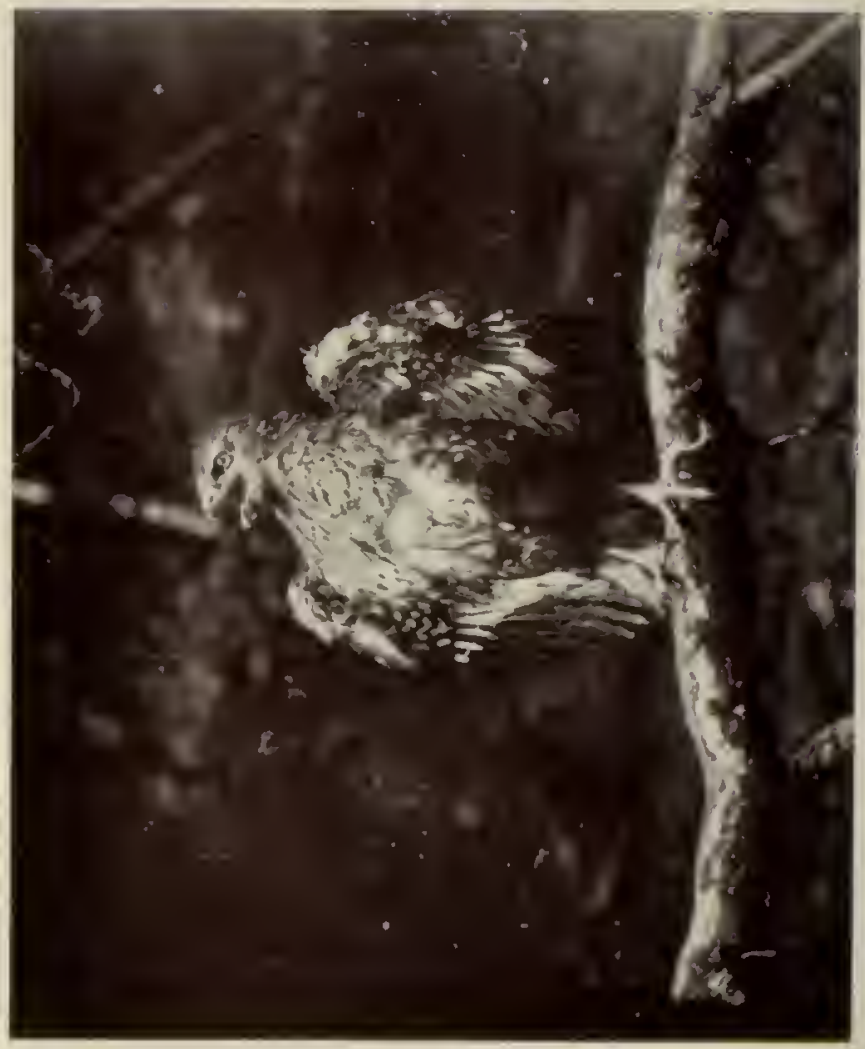




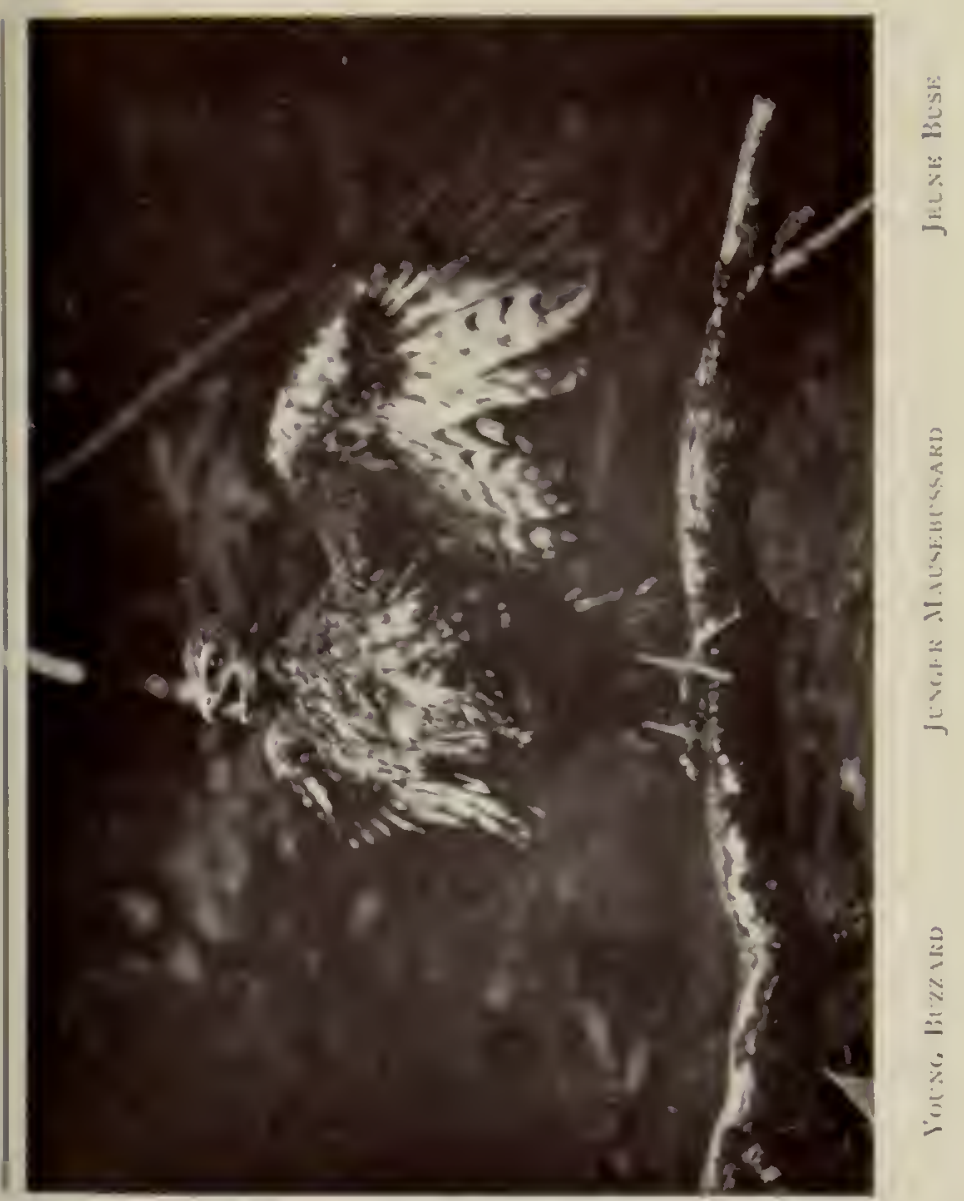




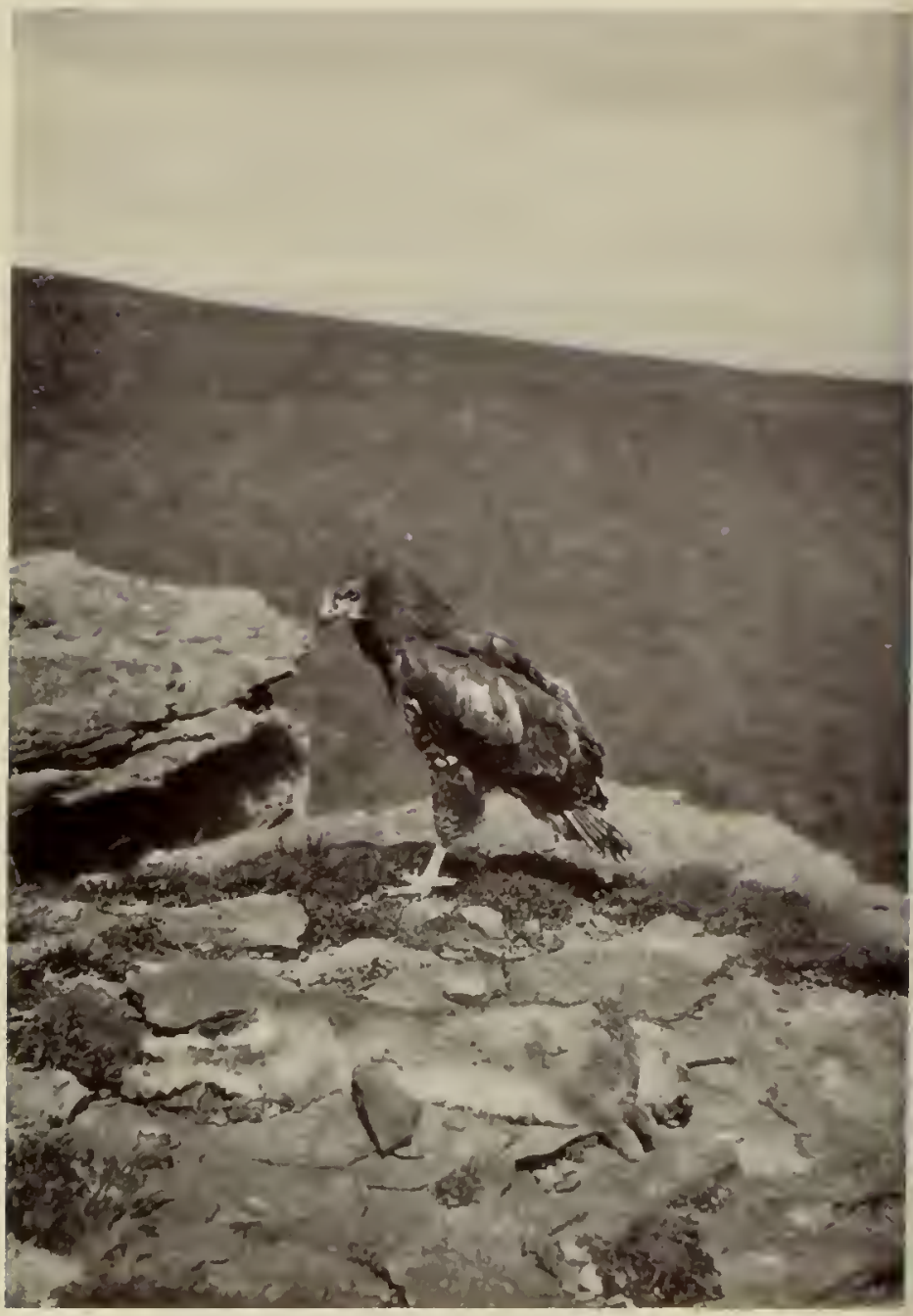

BUZZARI) (IMNATTIRE) BUSE (AVANT I Alik aDULTL) M.IUSEUUSSARH (UNIRU ALHSE) 


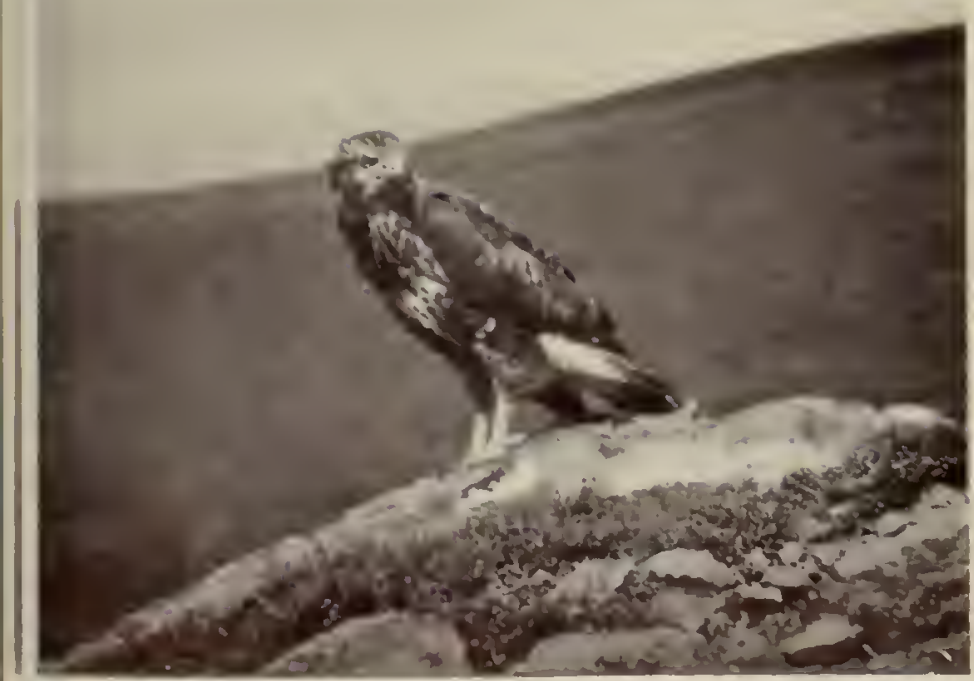




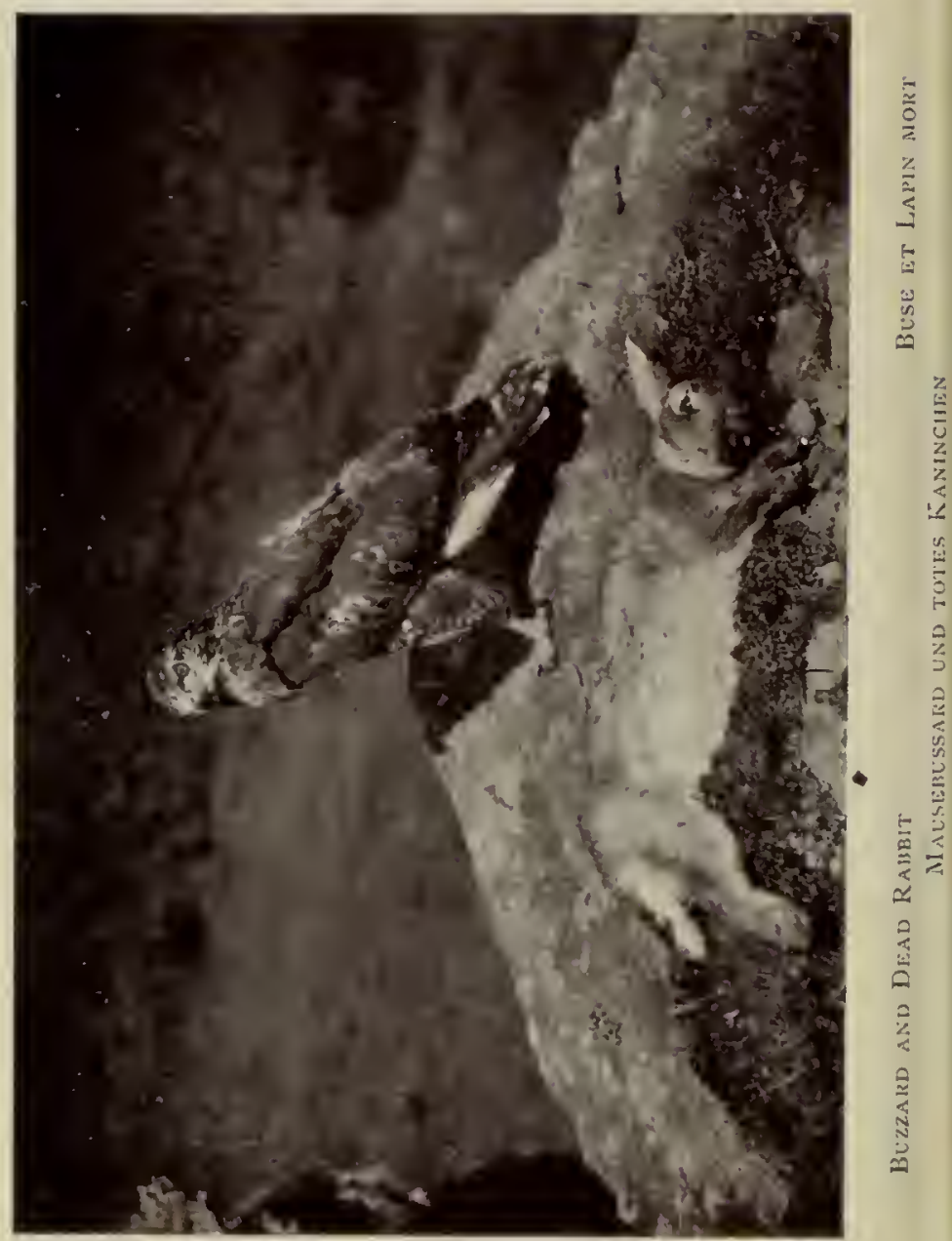




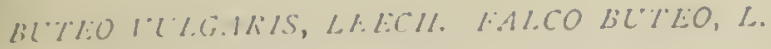

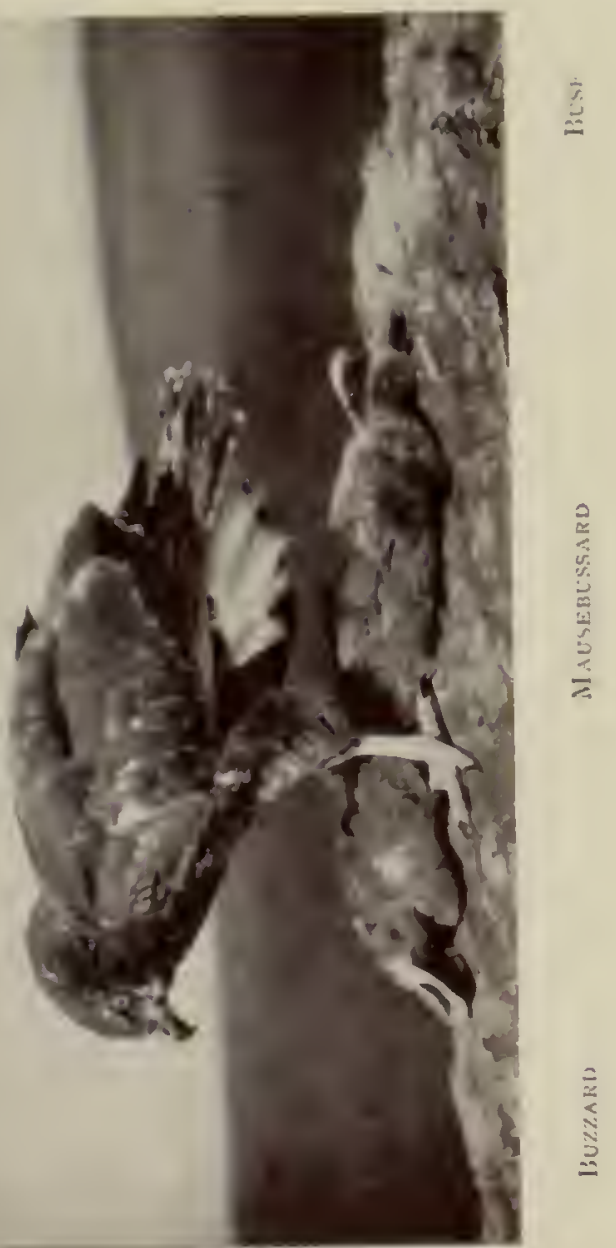




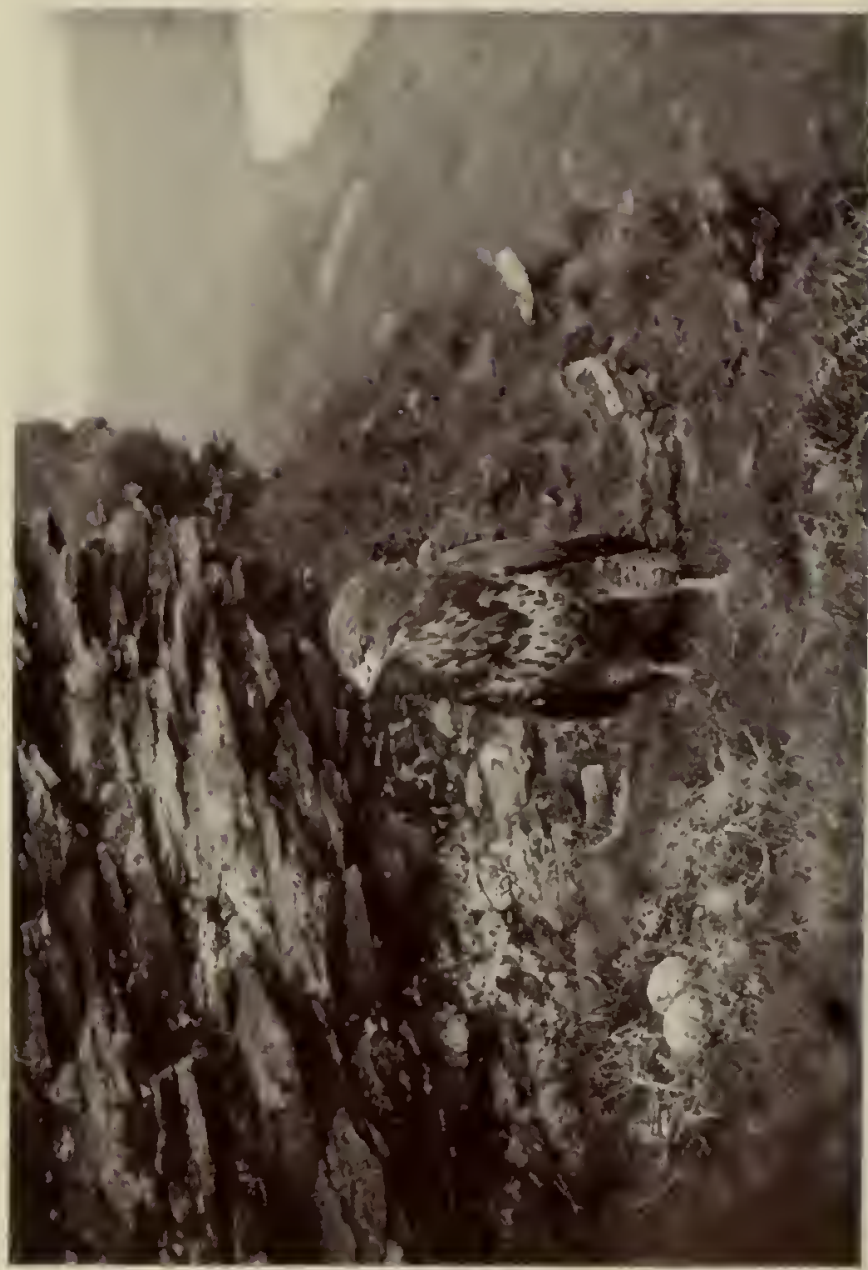




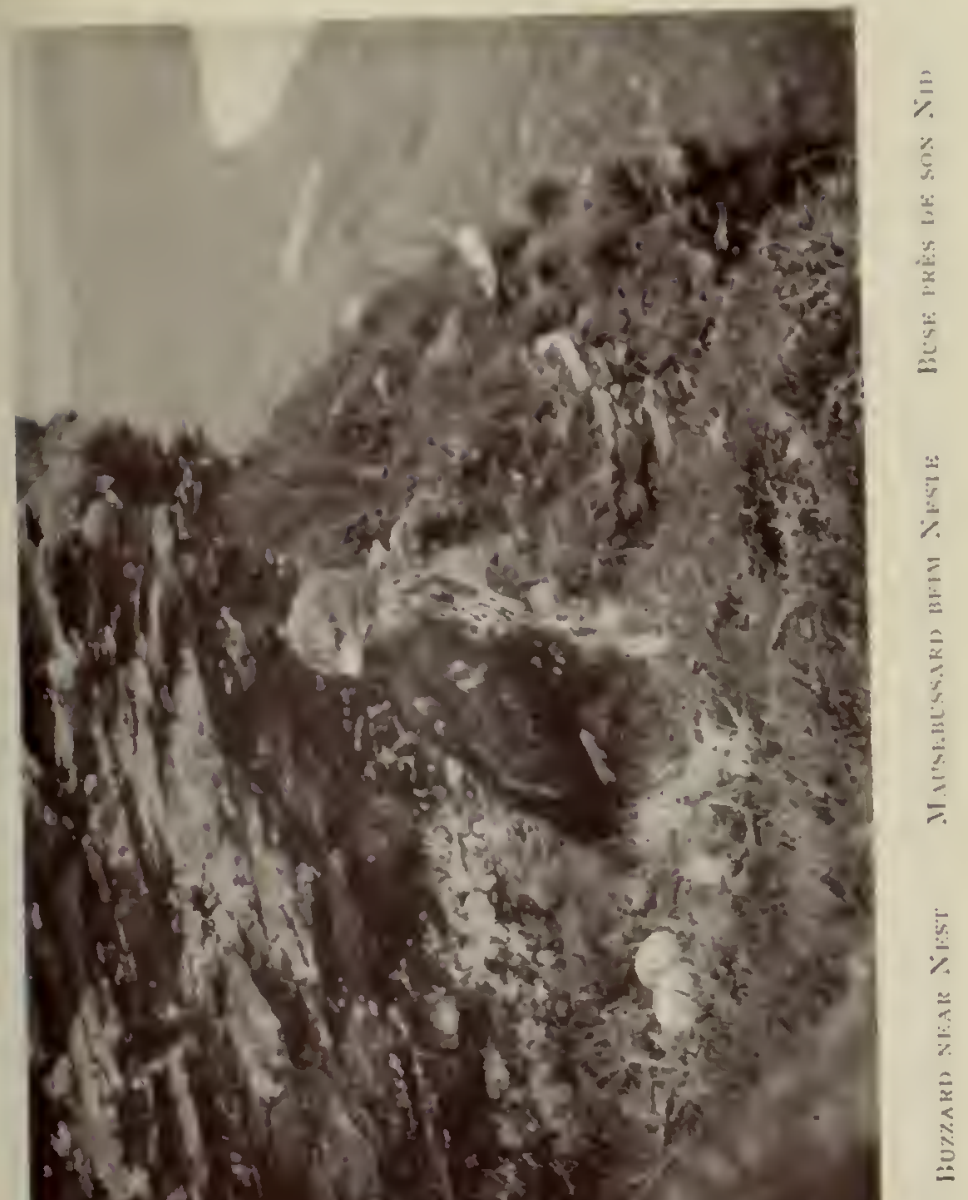


FALCO BLTEO,L.

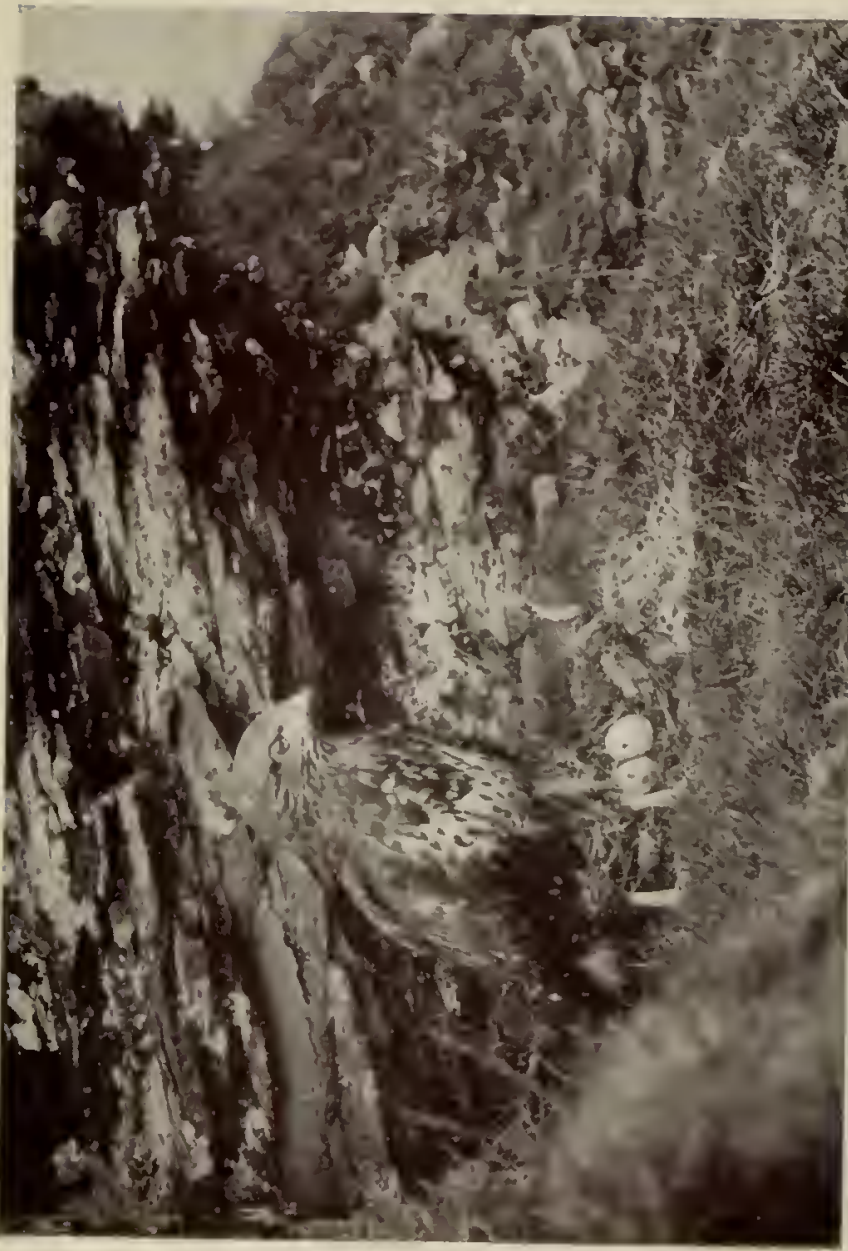

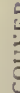

5

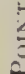

(

5

5

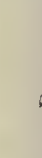

造

웅

? 


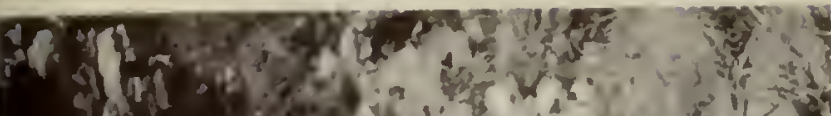

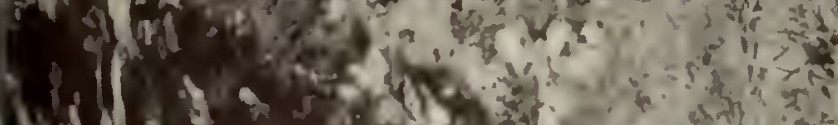

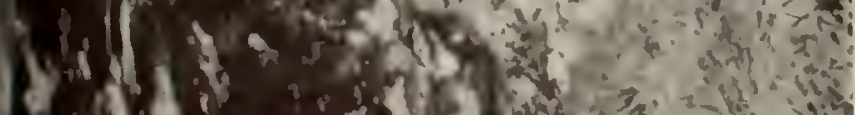

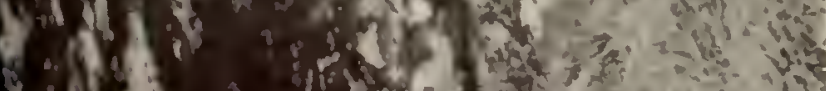

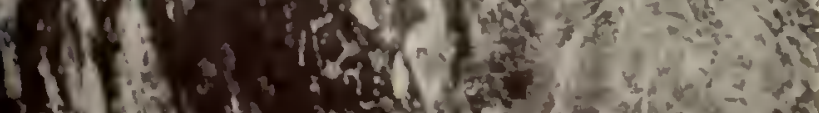

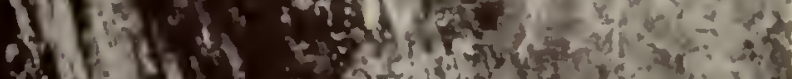
If

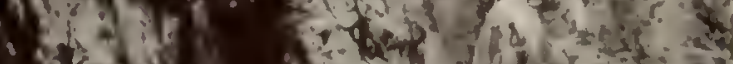
(1)

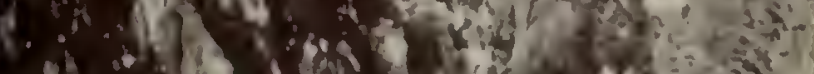

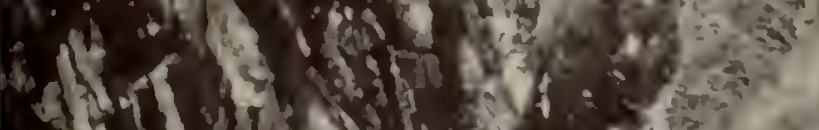

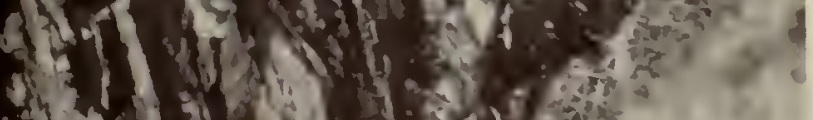

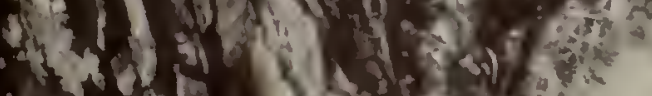

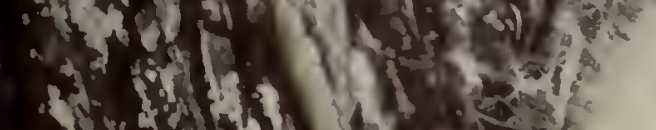

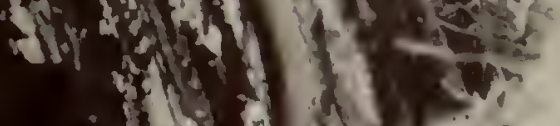

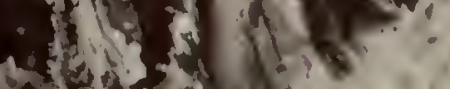

5
$\vdots$
$\vdots$
$\vdots$
$\vdots$
$\vdots$
$\vdots$
$\vdots$
$\vdots$
$\vdots$
$\vdots$
$\vdots$
$\vdots$

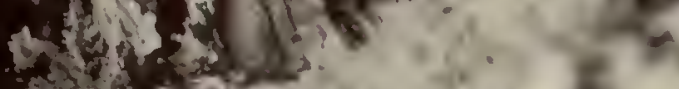
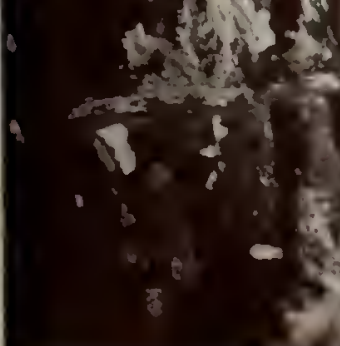

B.

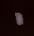

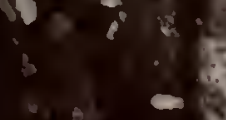

$x^{2}=$

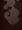

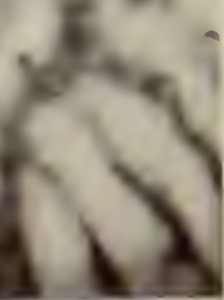

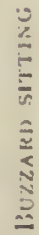




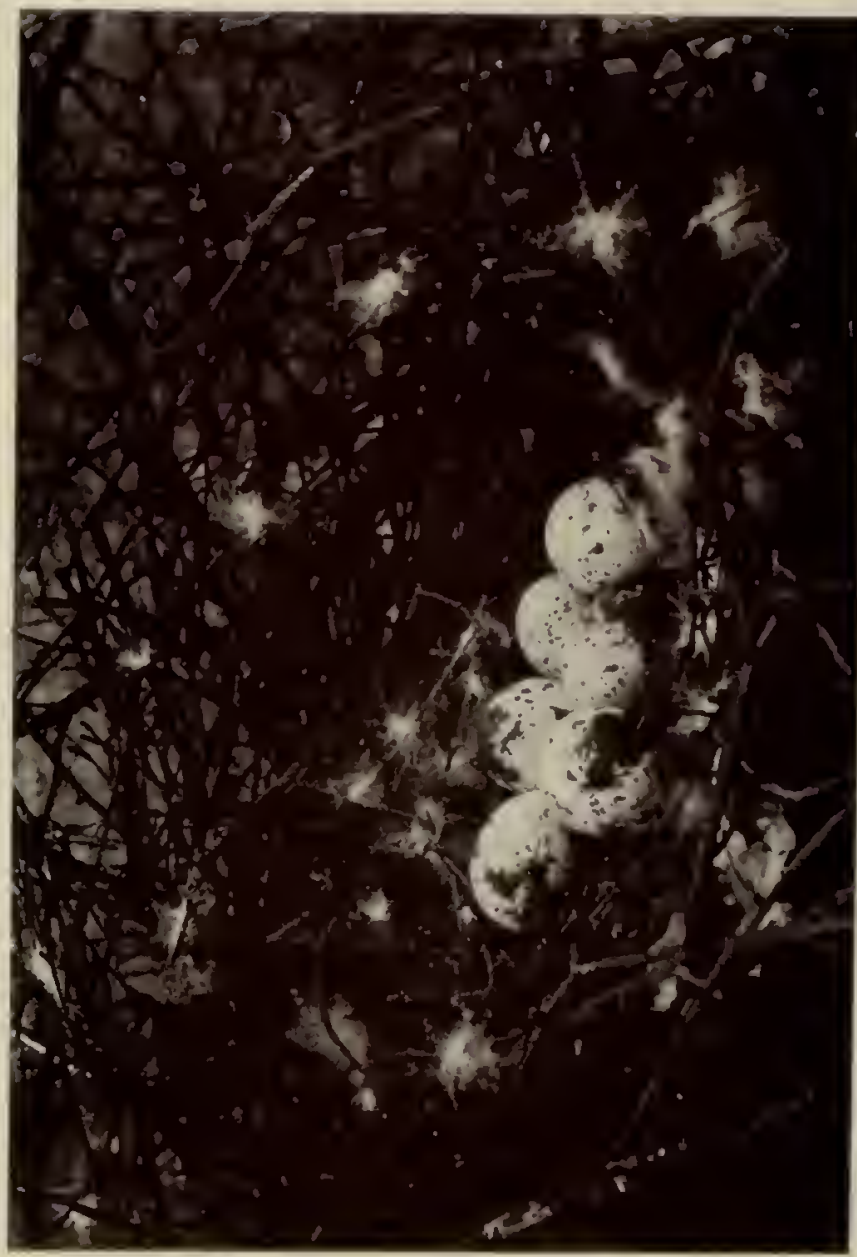

5
$\vdots$
5
5
5
5
5
5
5
5
5
5
5
5
5
5
5
5

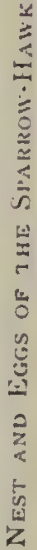




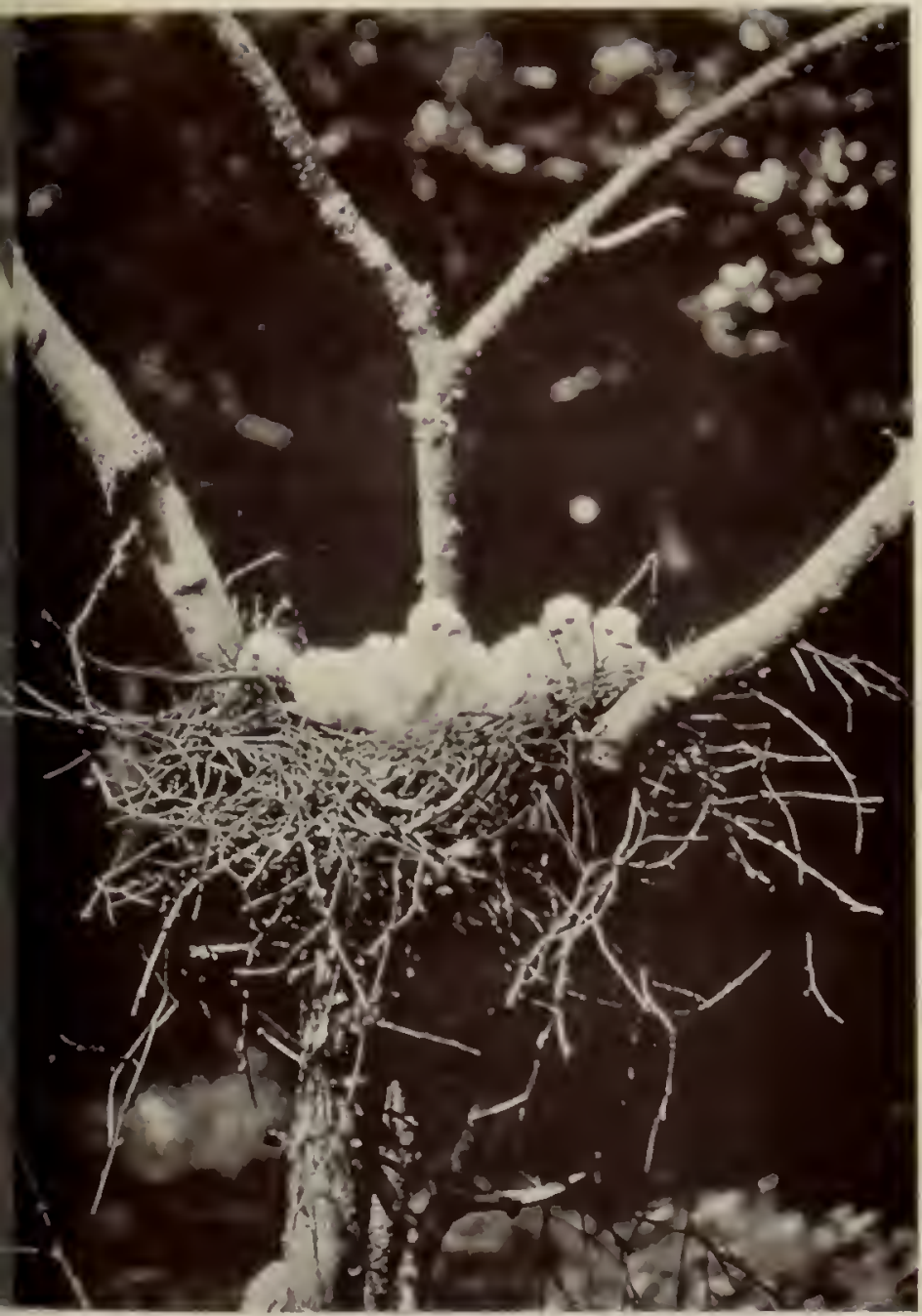

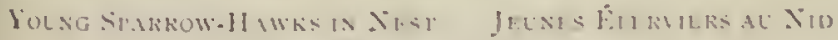
JURGE SPRELR IM NYSTL 


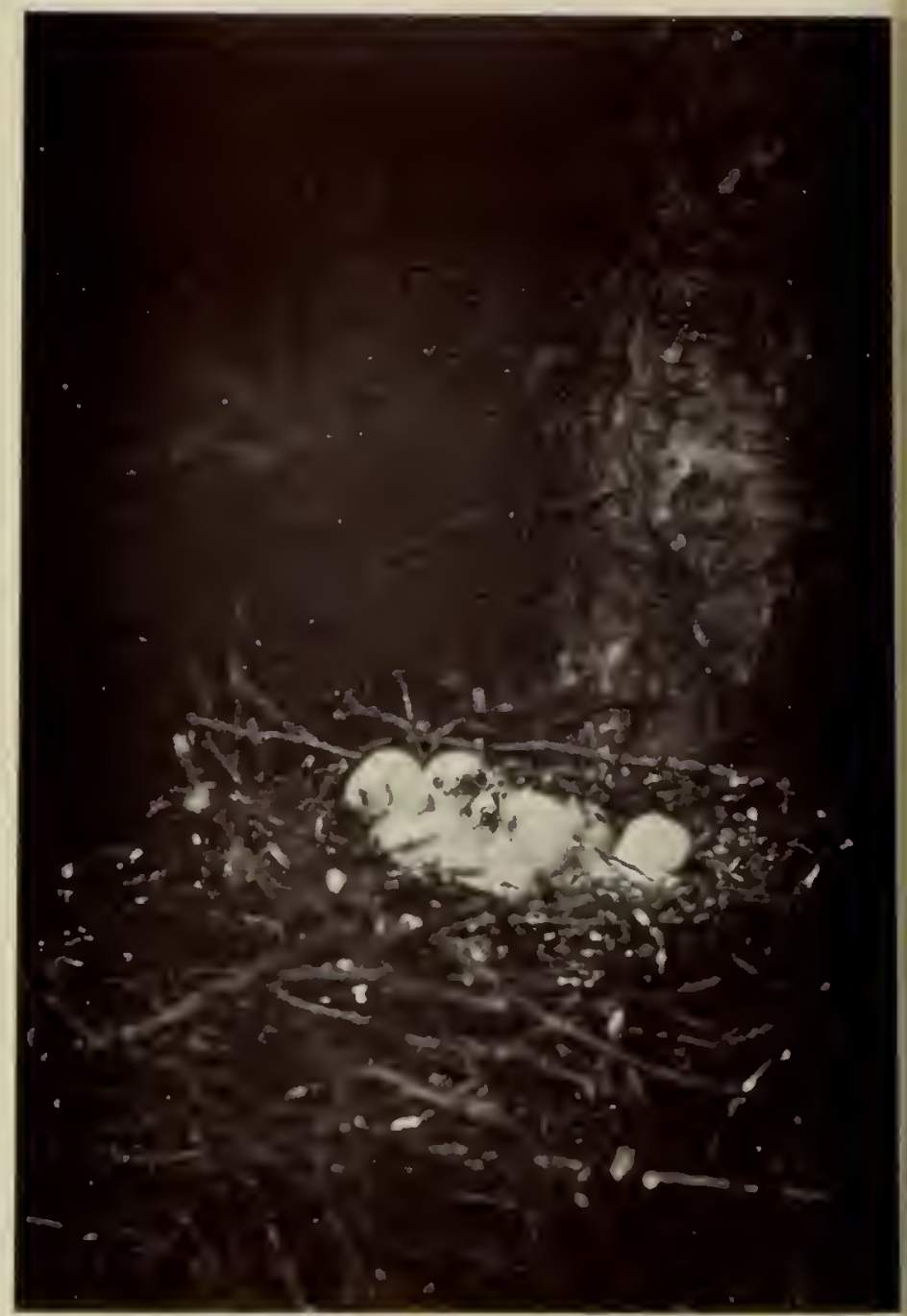

Six loung Sparrow-Hawks IN NEST

SIX IEUNTS ÉPERTIERS AU Nid

SECHS JUNGi: SPERHER IM NESTE 


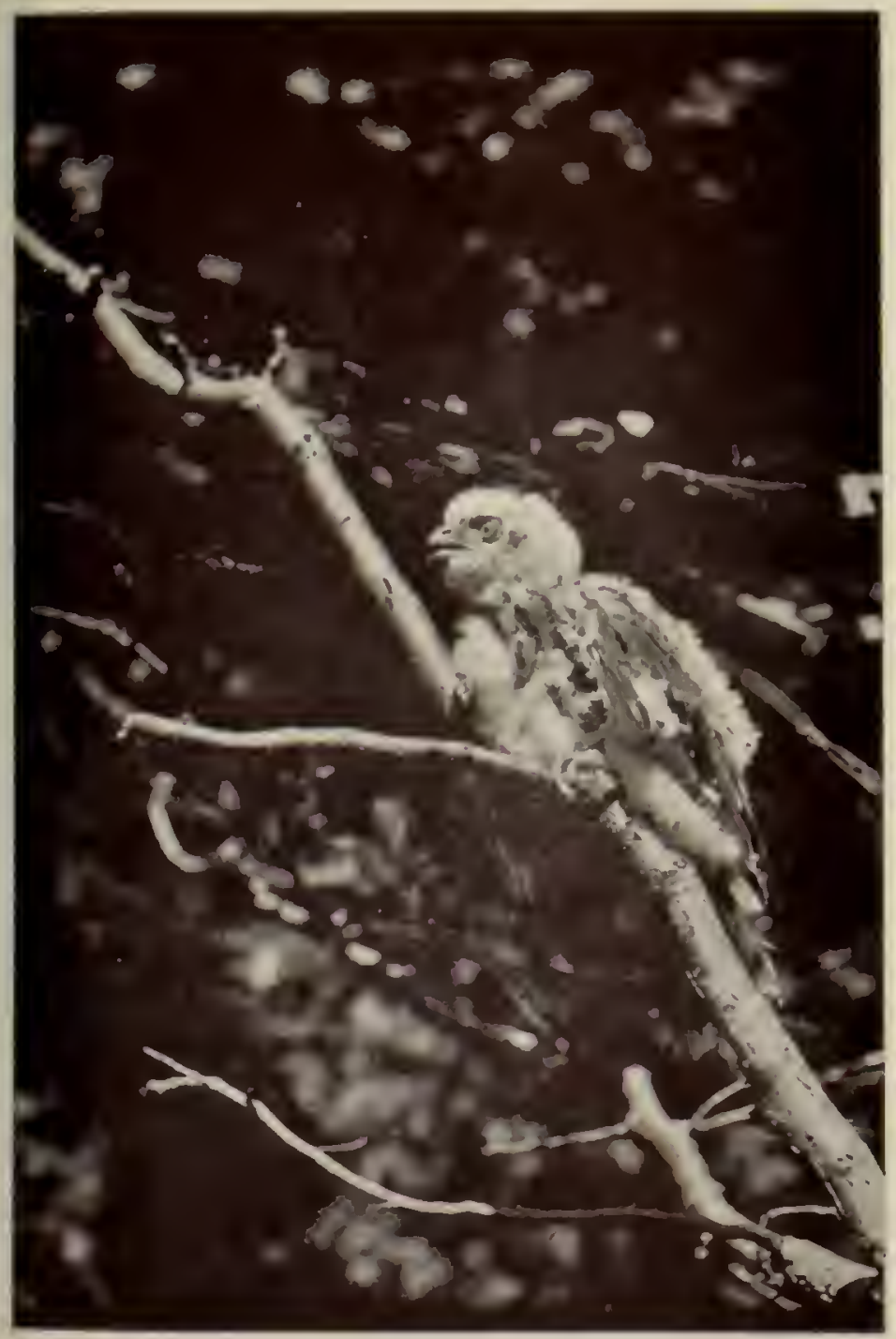

lotwg Stakrow-Hawk Junger Sperber Jetwe Éperiter 


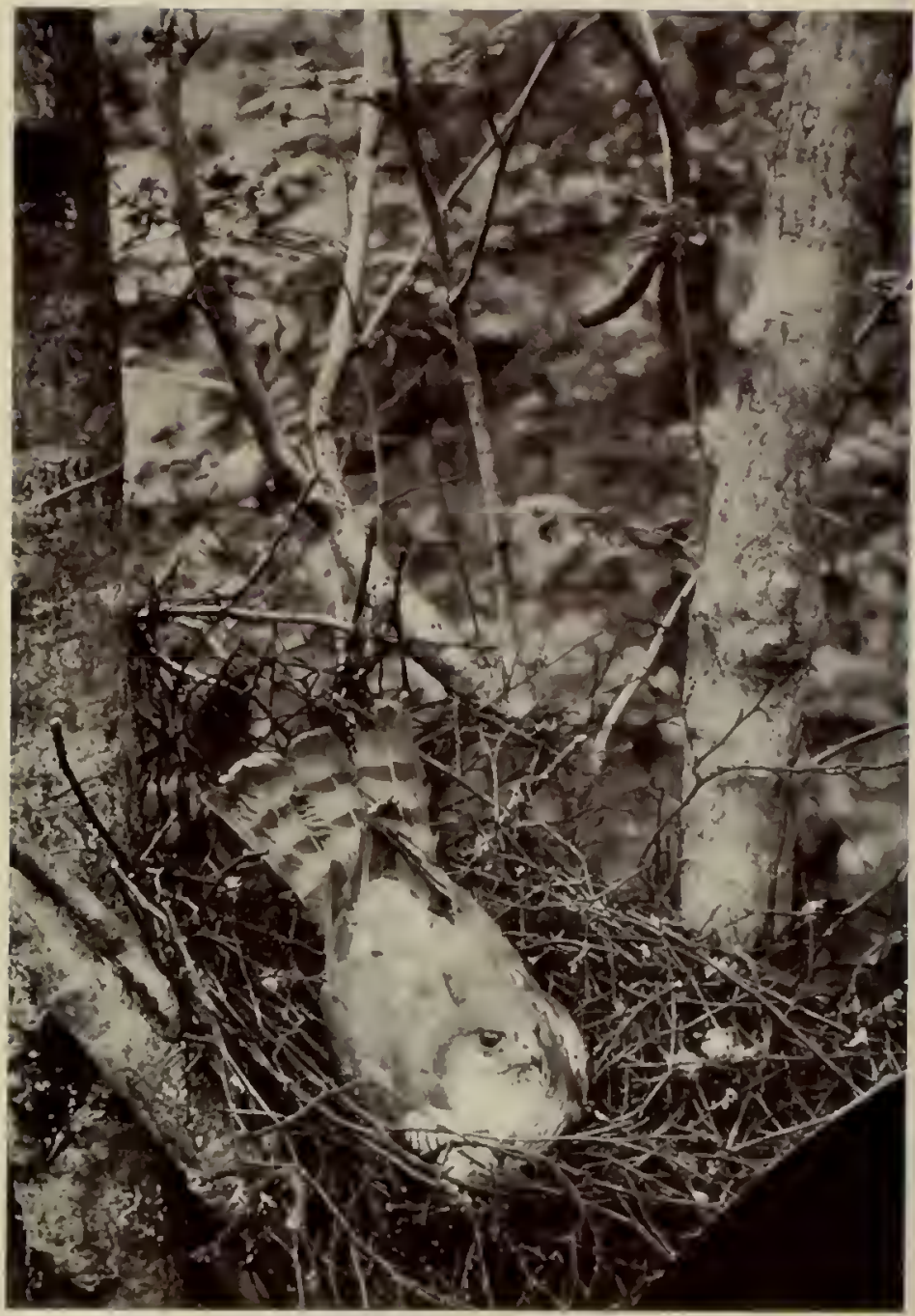

Sparrow-HaWl ON Nest EPERTER aU Nil SPERBER AUF DEM NIESTE 


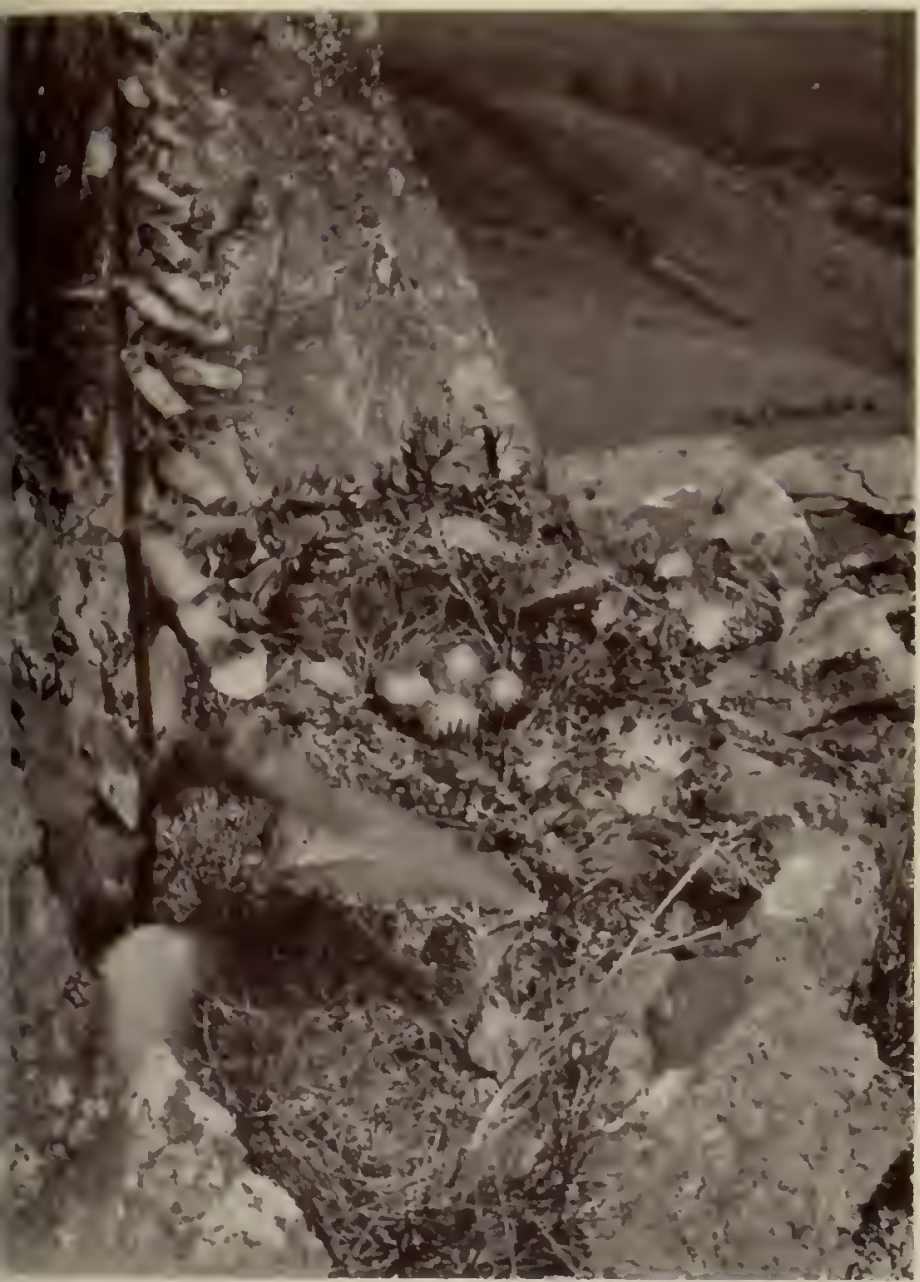

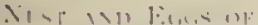

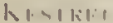

Vin t I I FS UR l'AteOs

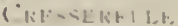

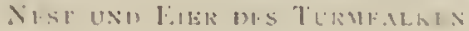


FALCO TINNUNCULUS, L.

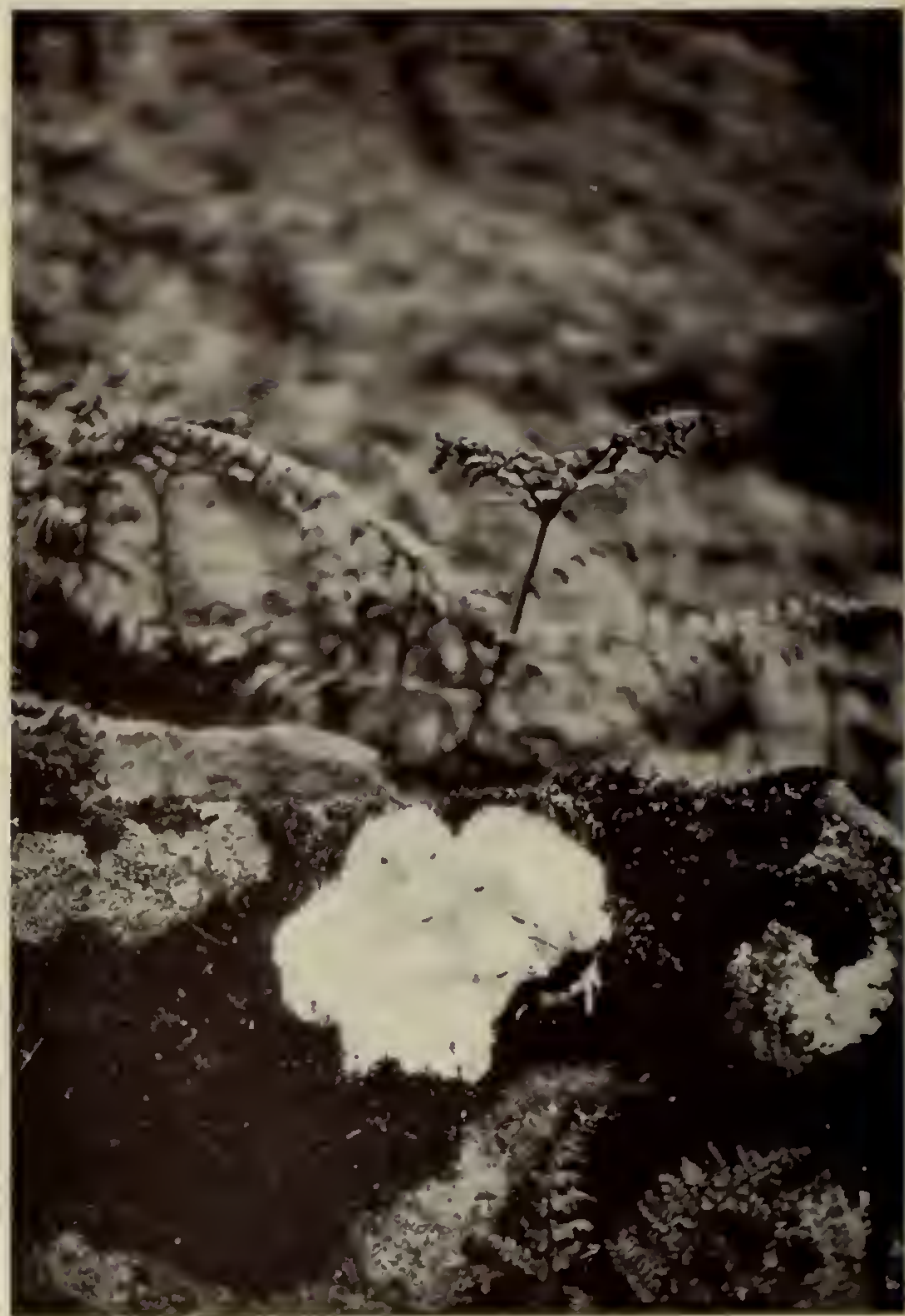

Young Kestrel.s JUNGe TURMFalkiN Jlunes Cresserellis 


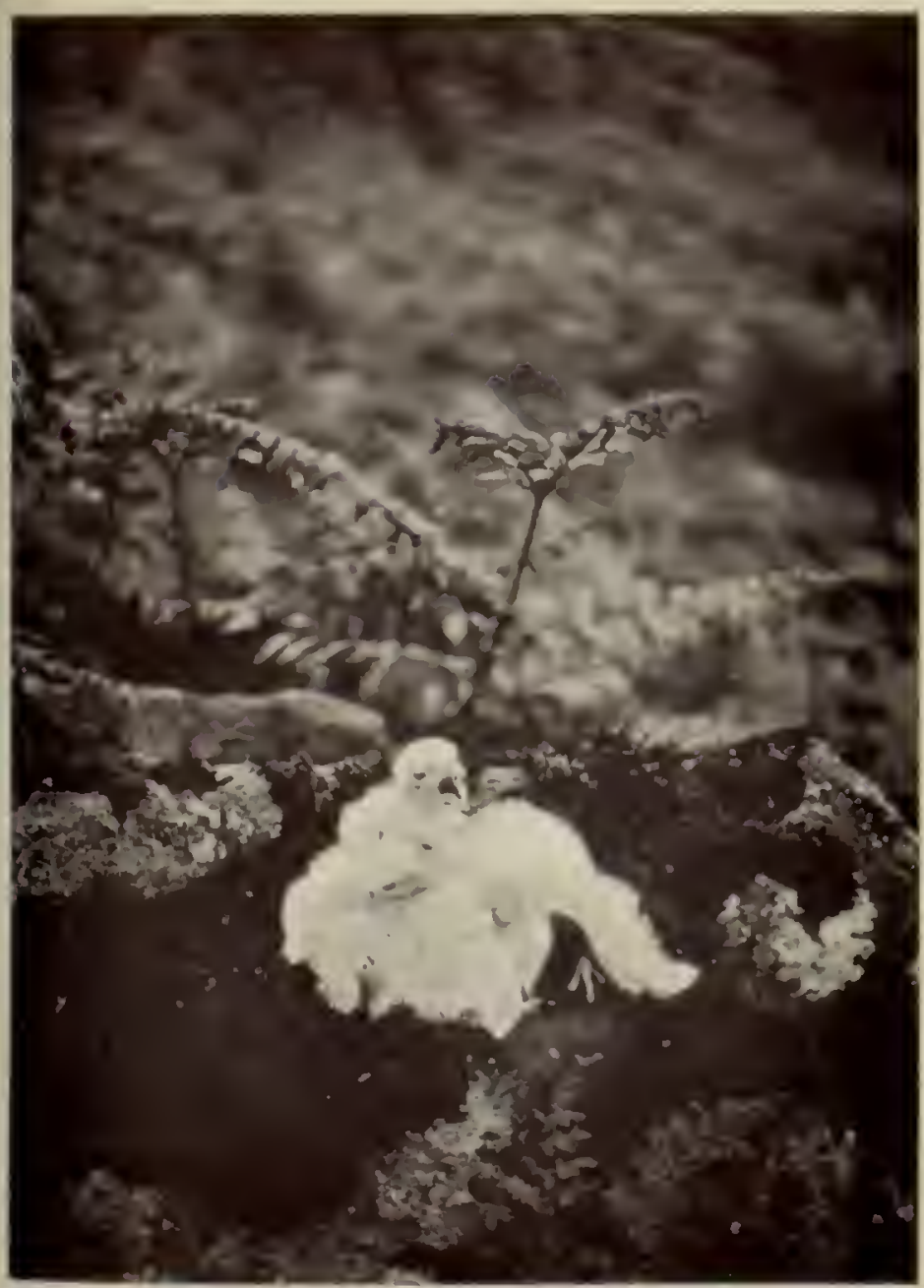

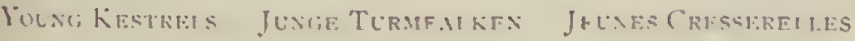




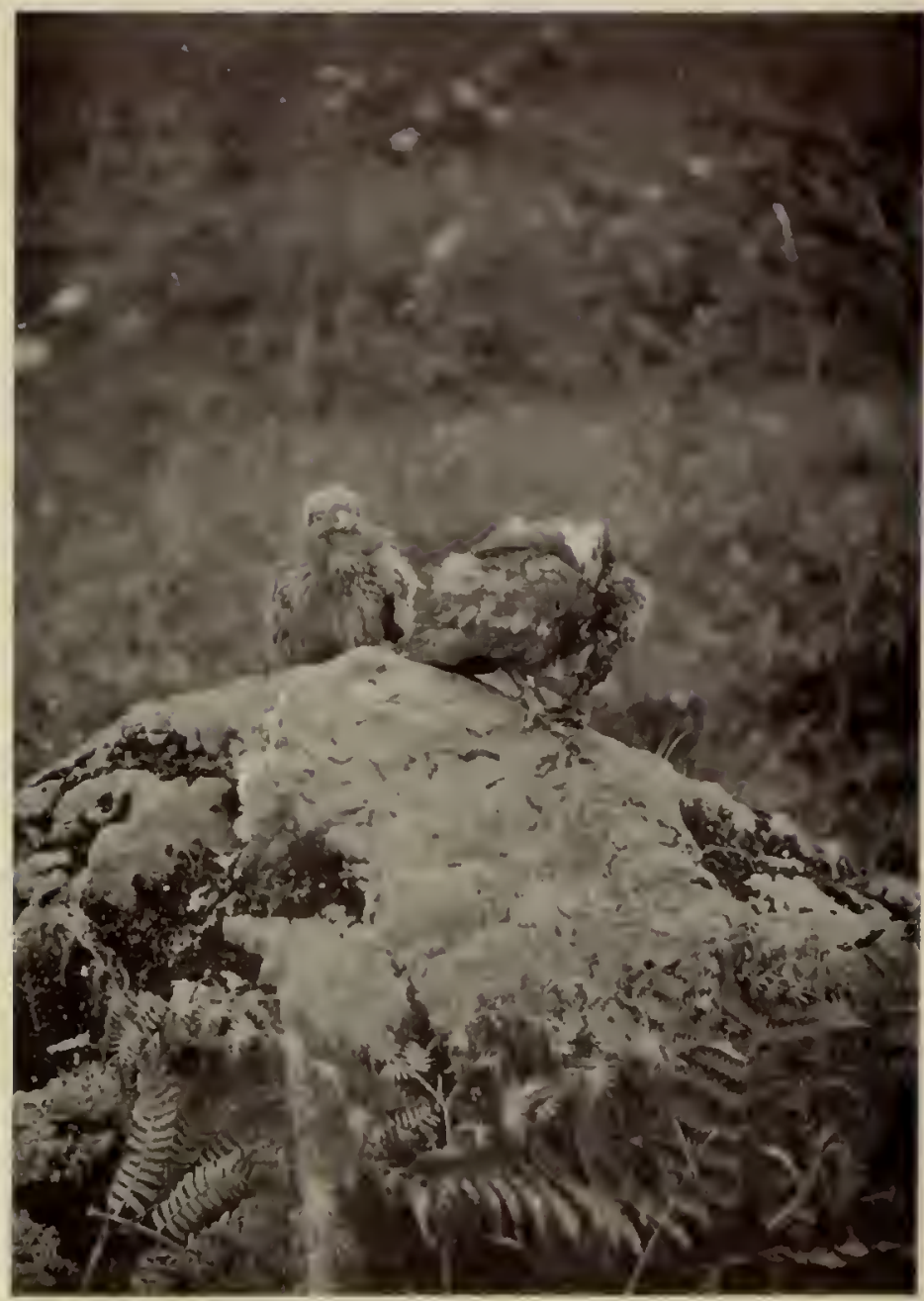

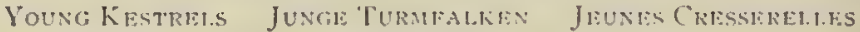




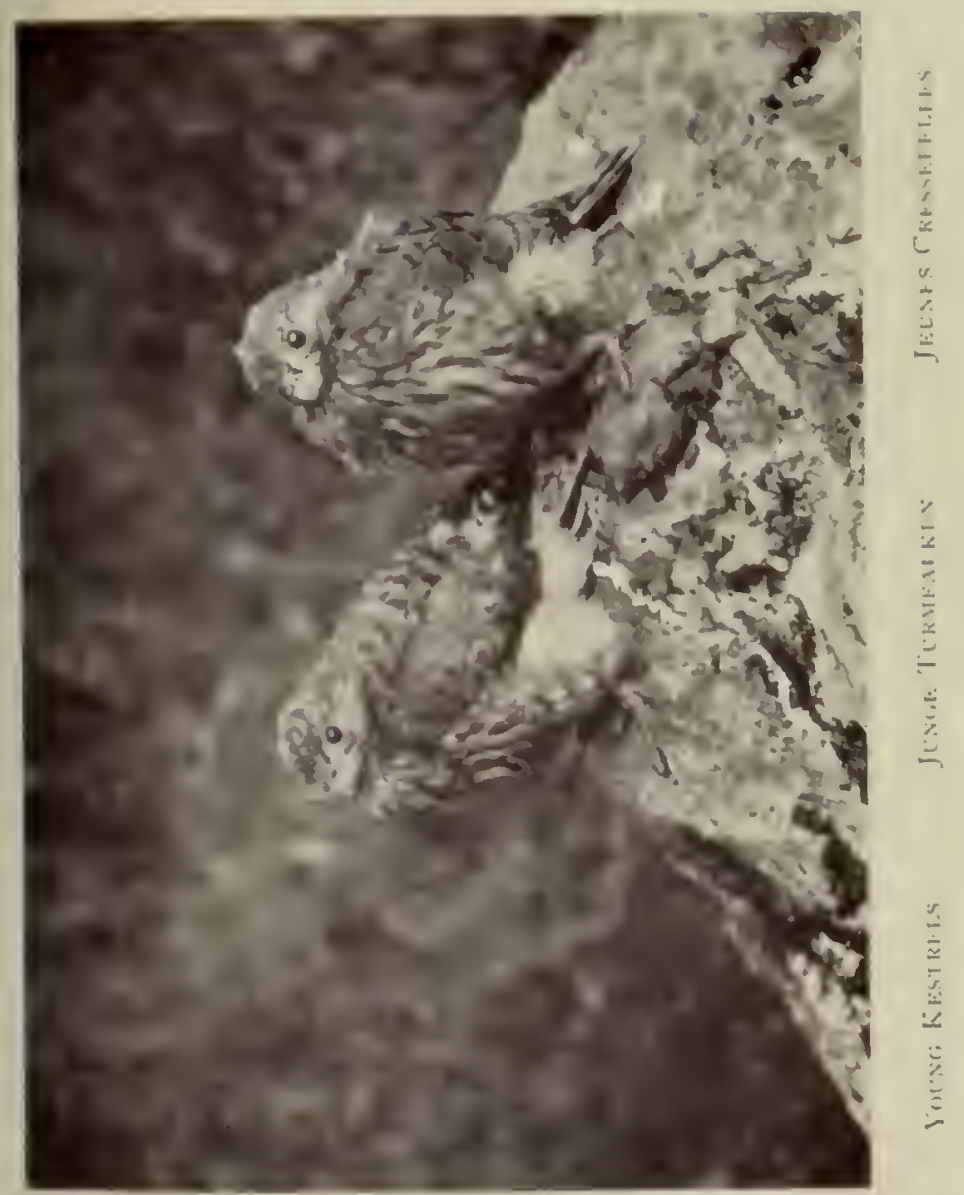




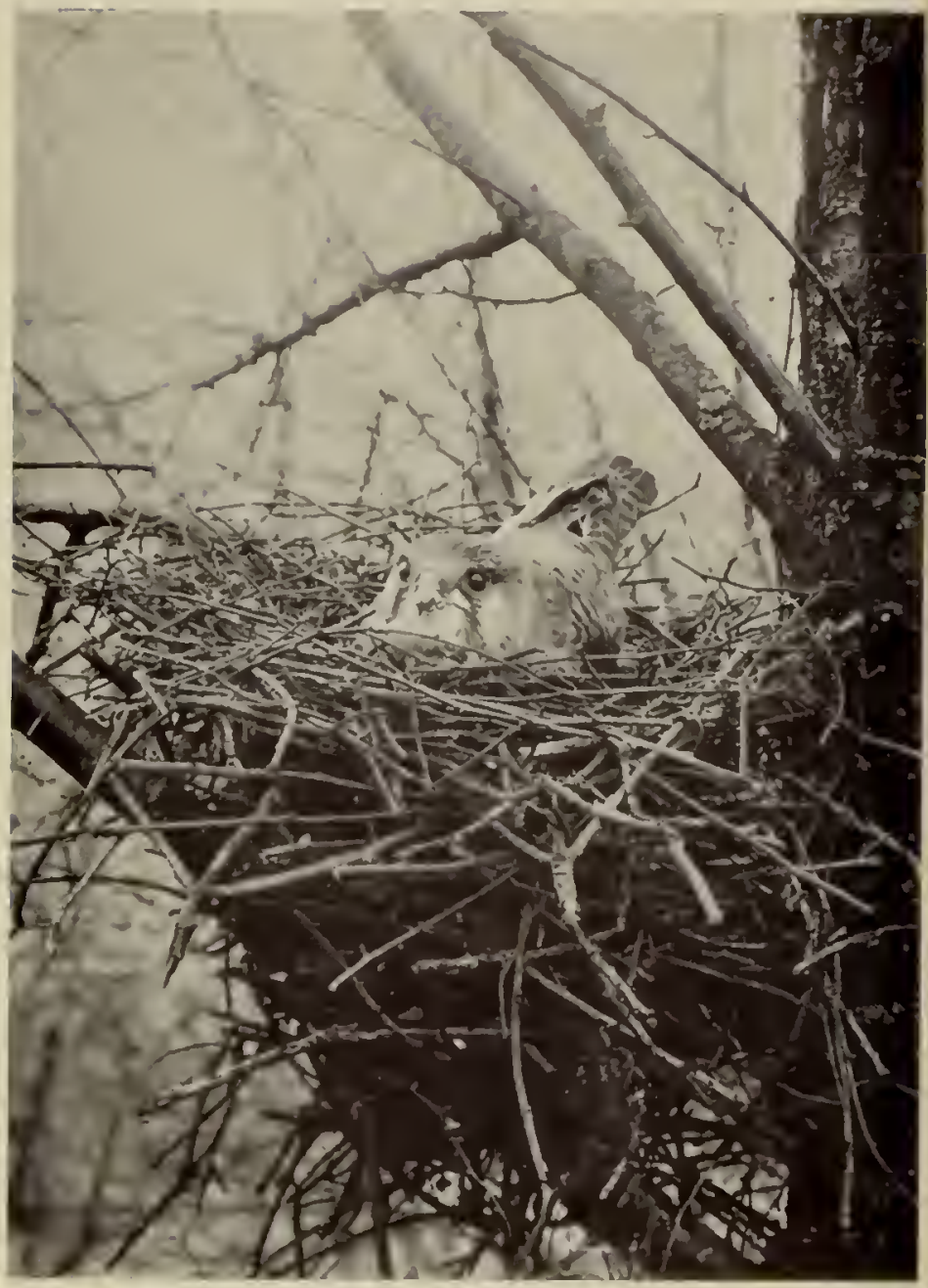

KestReL on Nust Cresserelle au Nid TURMFalke aUF deM Neste 


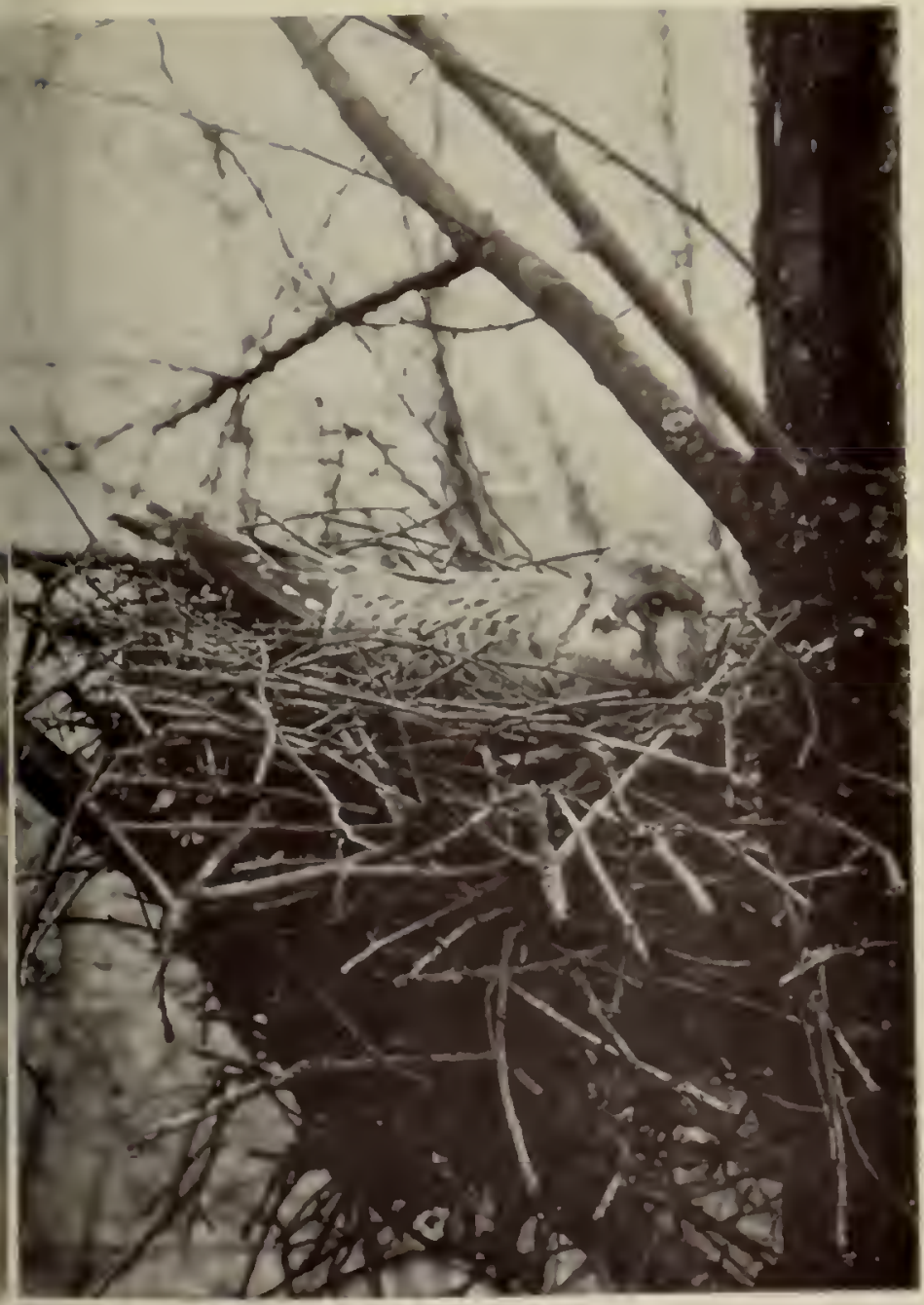

Kesthe1. "N Xin

Cresstrelle ut

TUKMHALKE ALF UEM DESTE 


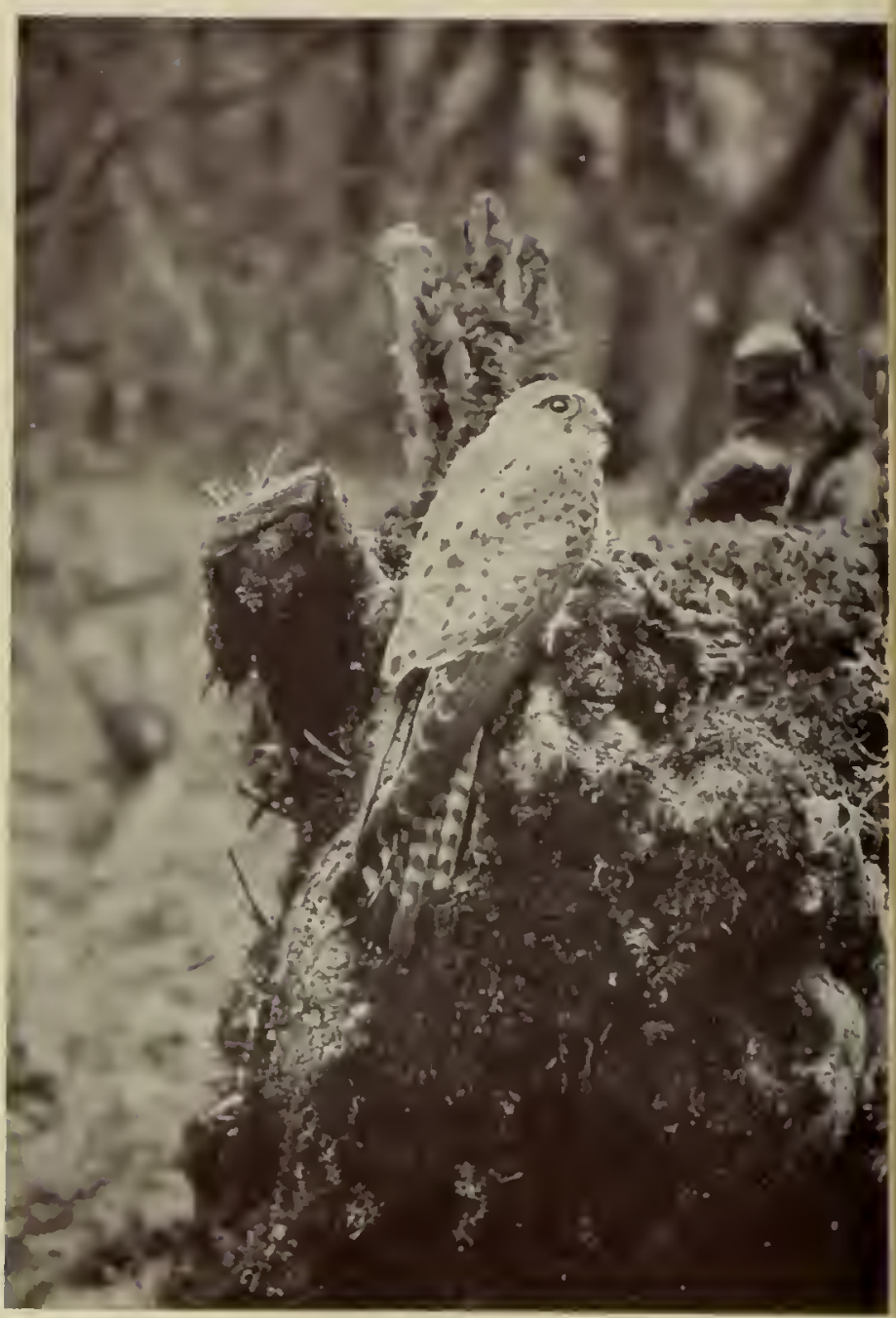

Kistrel near Nest

CRESTERE1.1: IRLS DE SON NID IURMFALKE 1BEIM NISSIE 


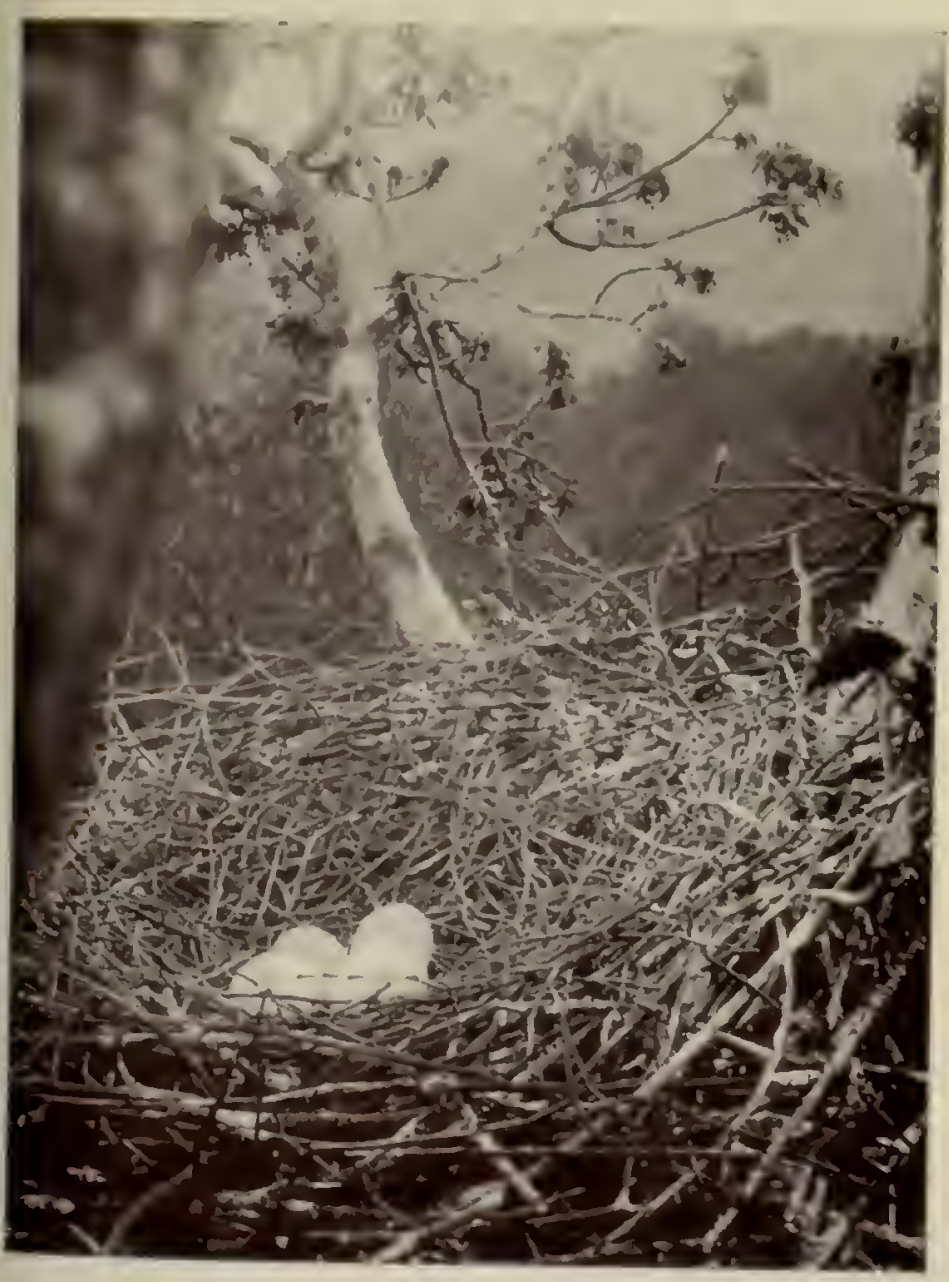

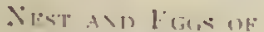

CiMMes: HFReN

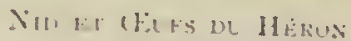
CE\DRE

XEST L ND liEK DES FISCMRETHENS 


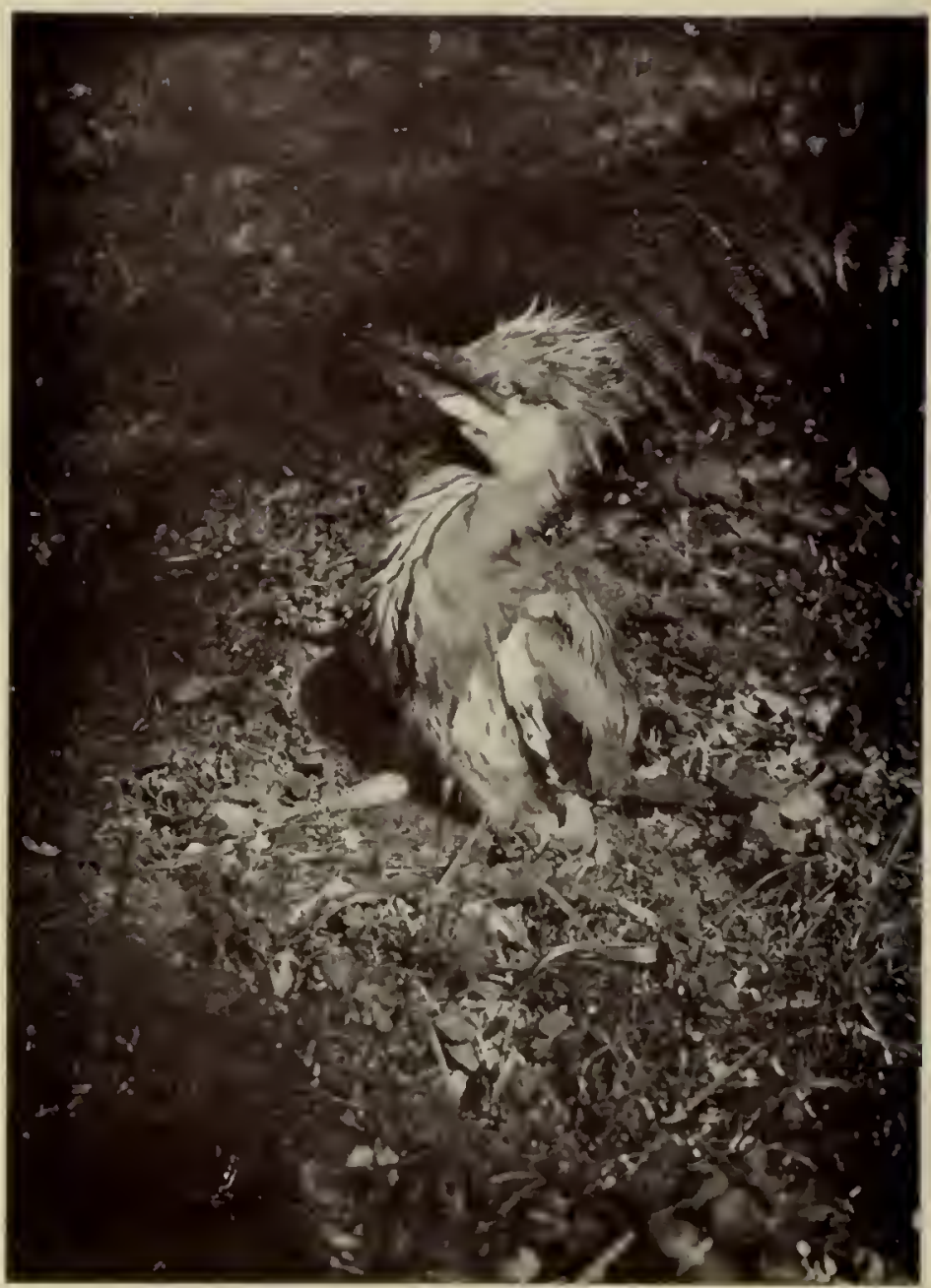

Joung fleliun Junger fischrethele Jeune Héron cles dri 


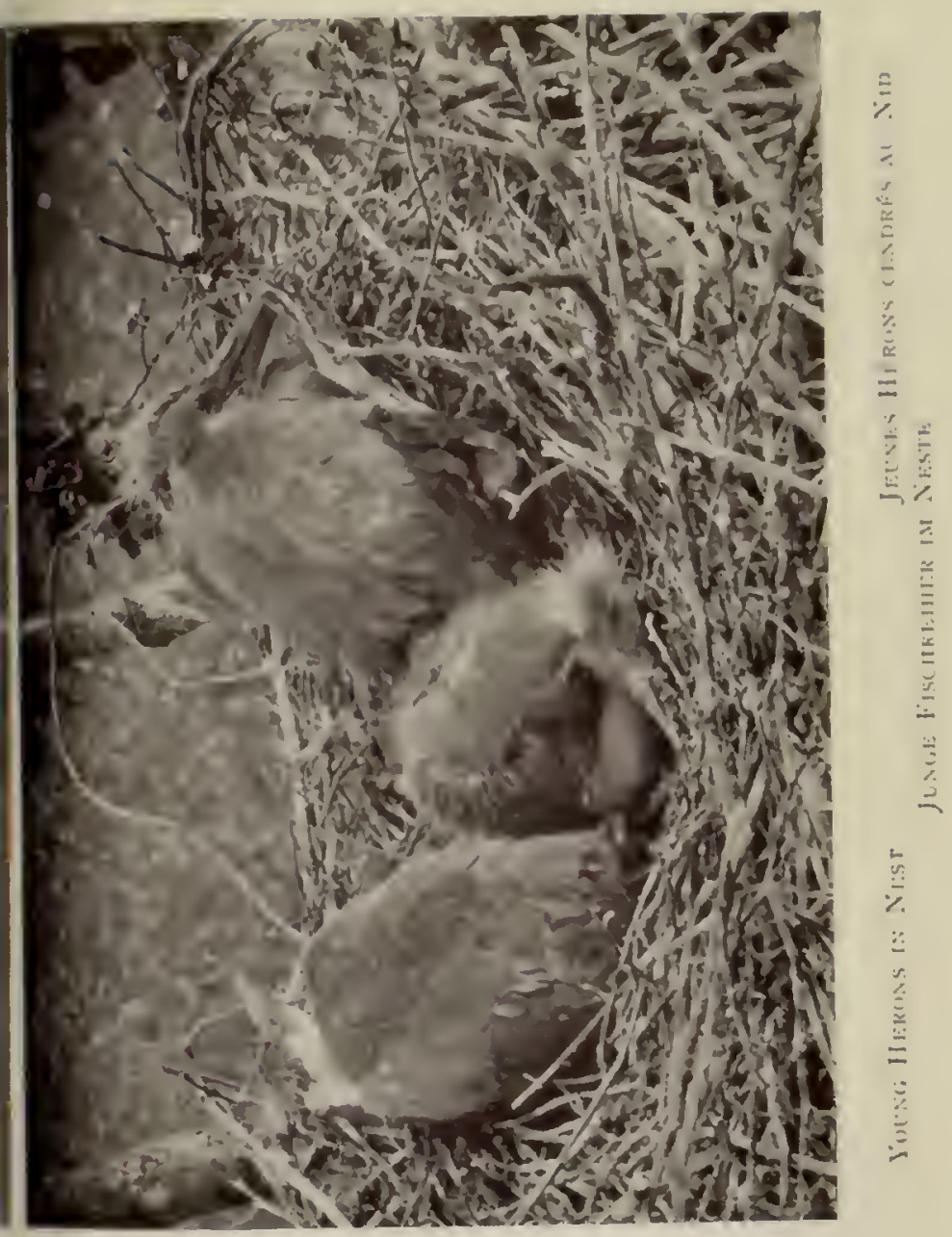




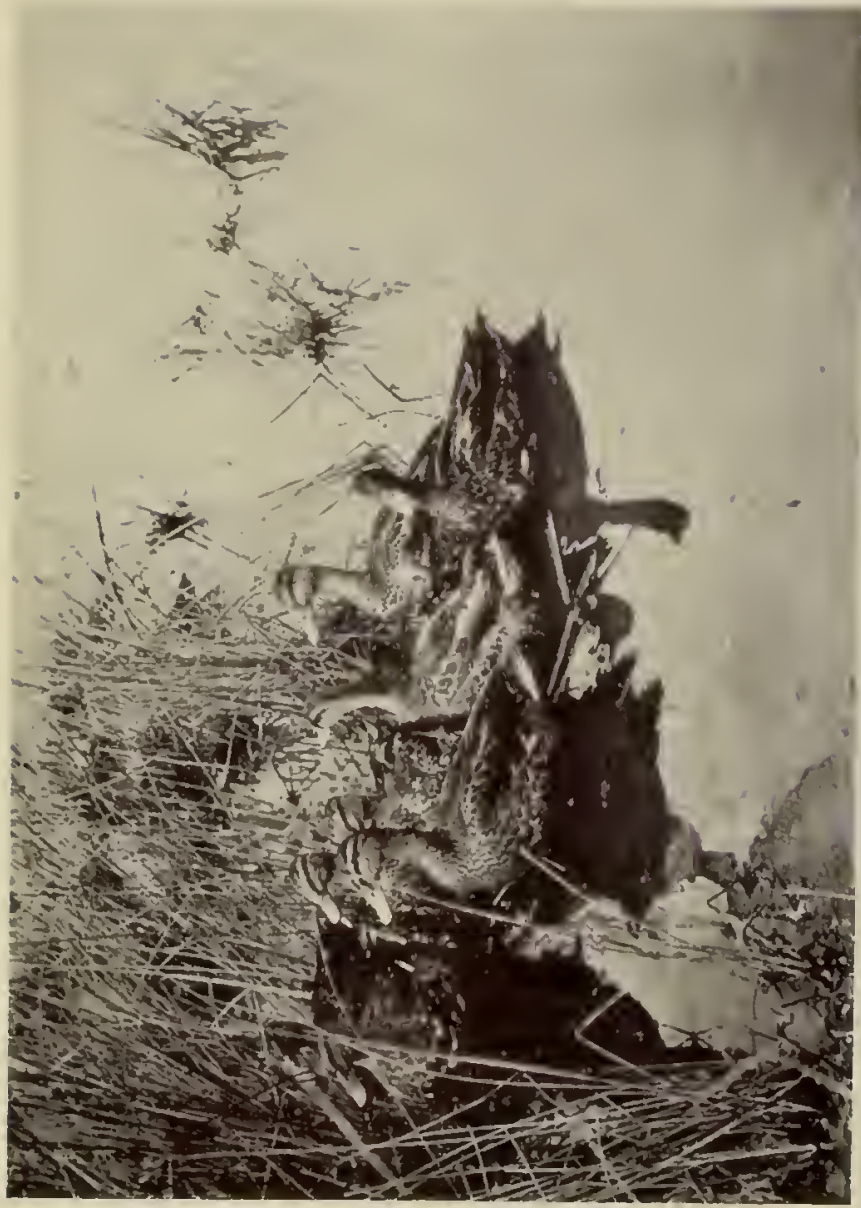




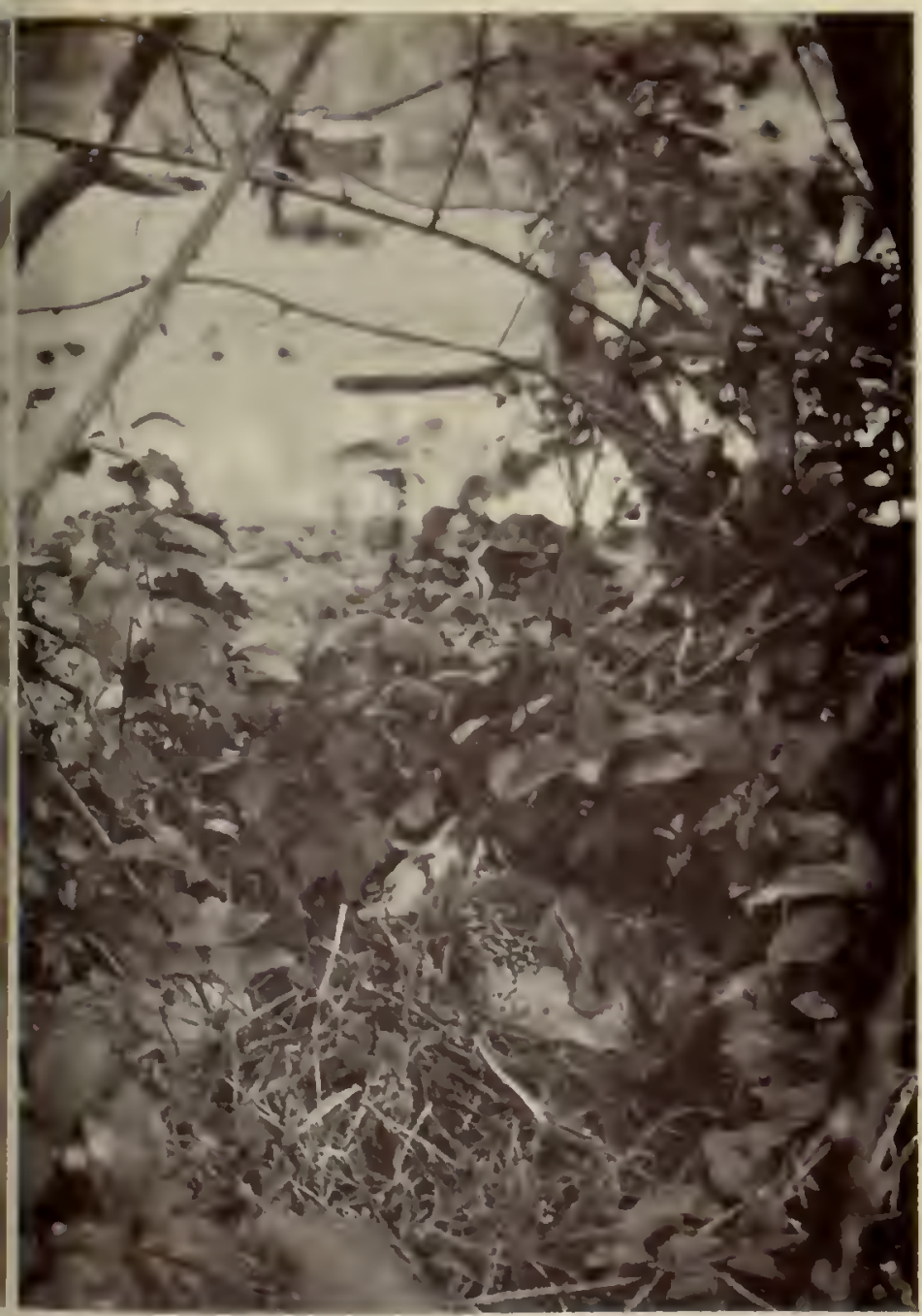

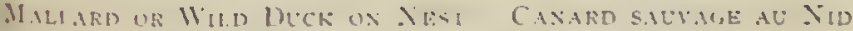
UILUESTE ALF DEM CIESTL 


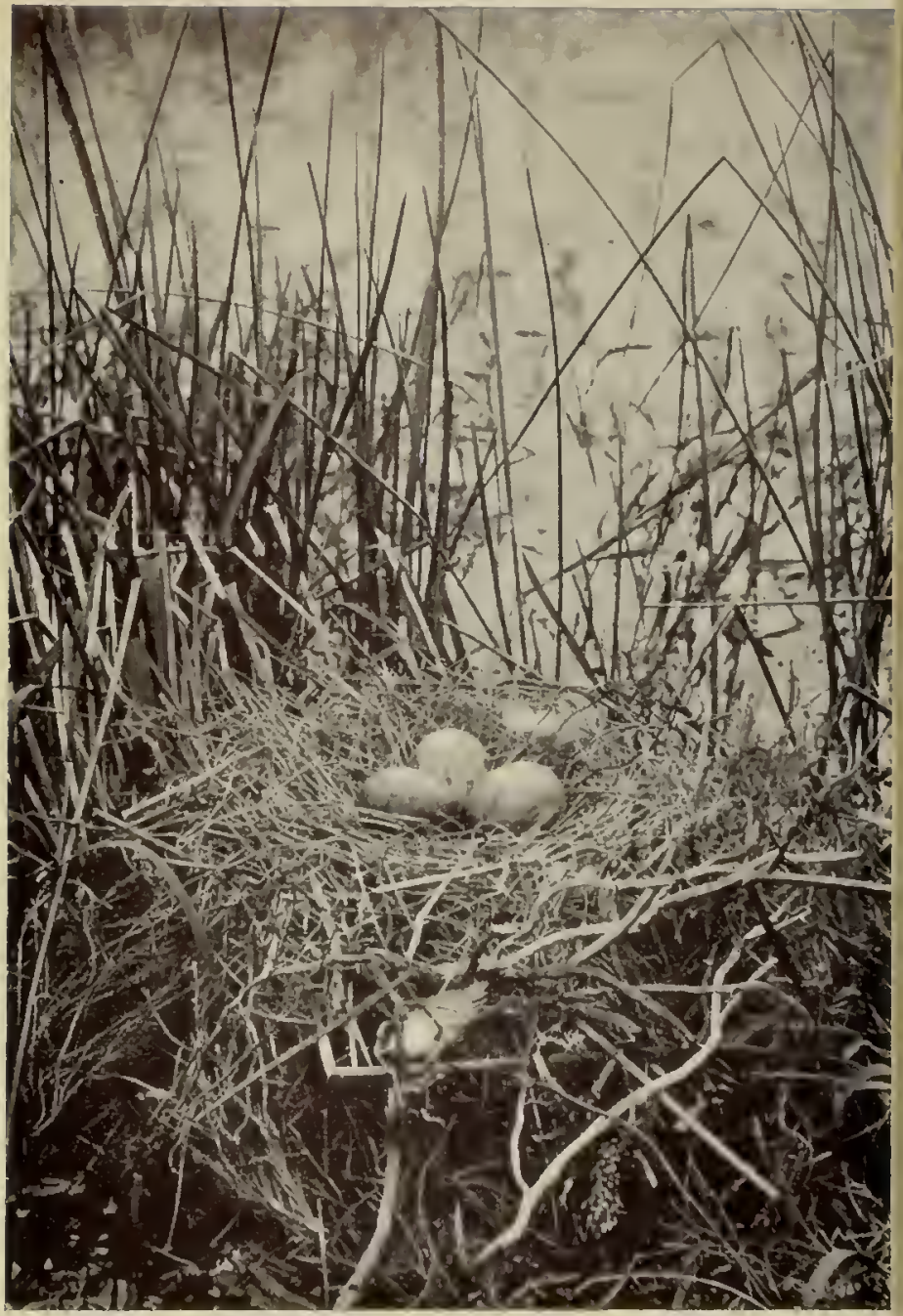

NEST AND Erigs OF BI.ACK. IEADED GULLL

Nid et Gufs du GoÉt.and BRUN

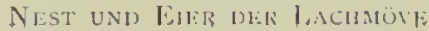


I.ARIS RIDIBUNDIS, L.

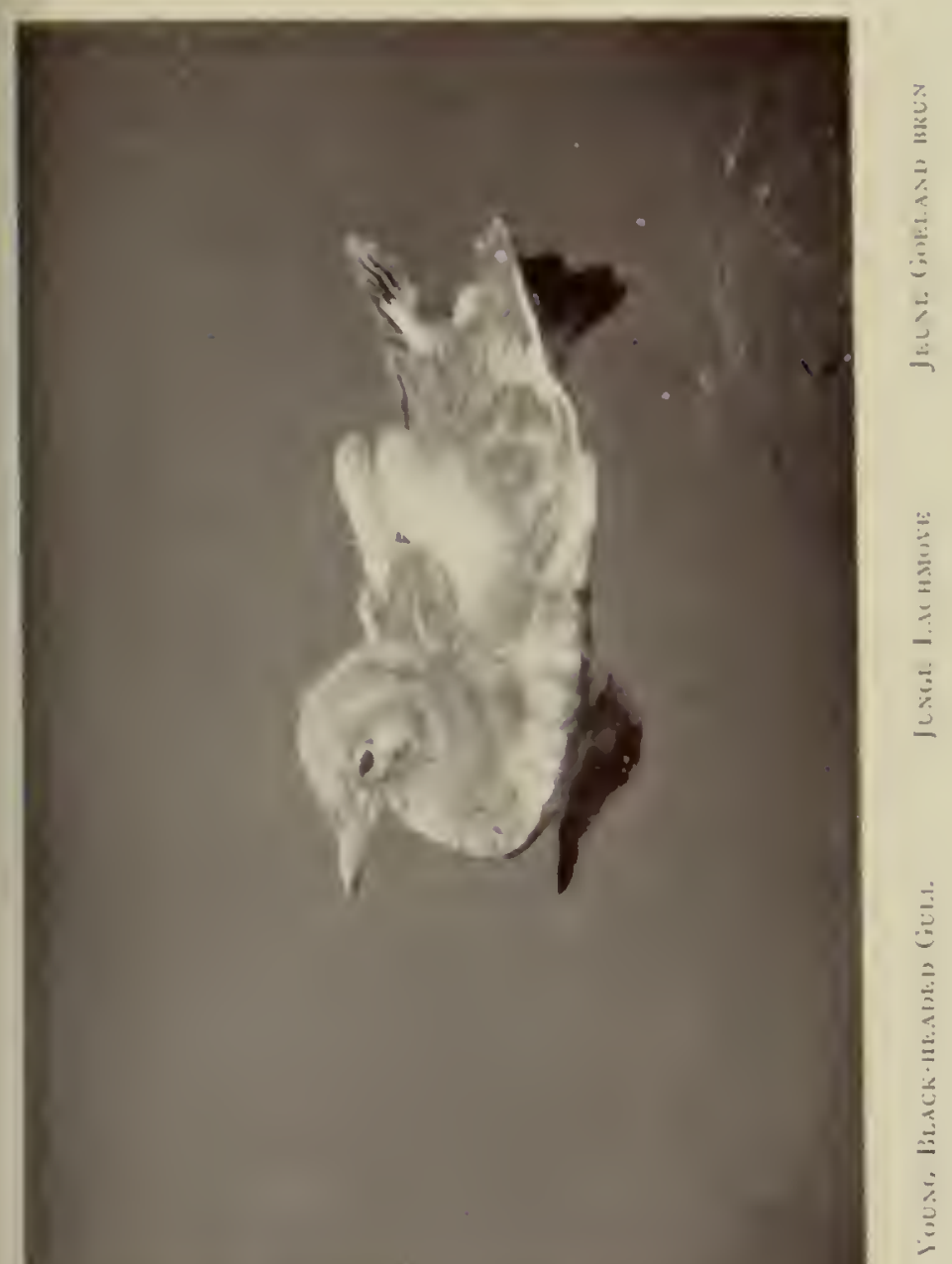




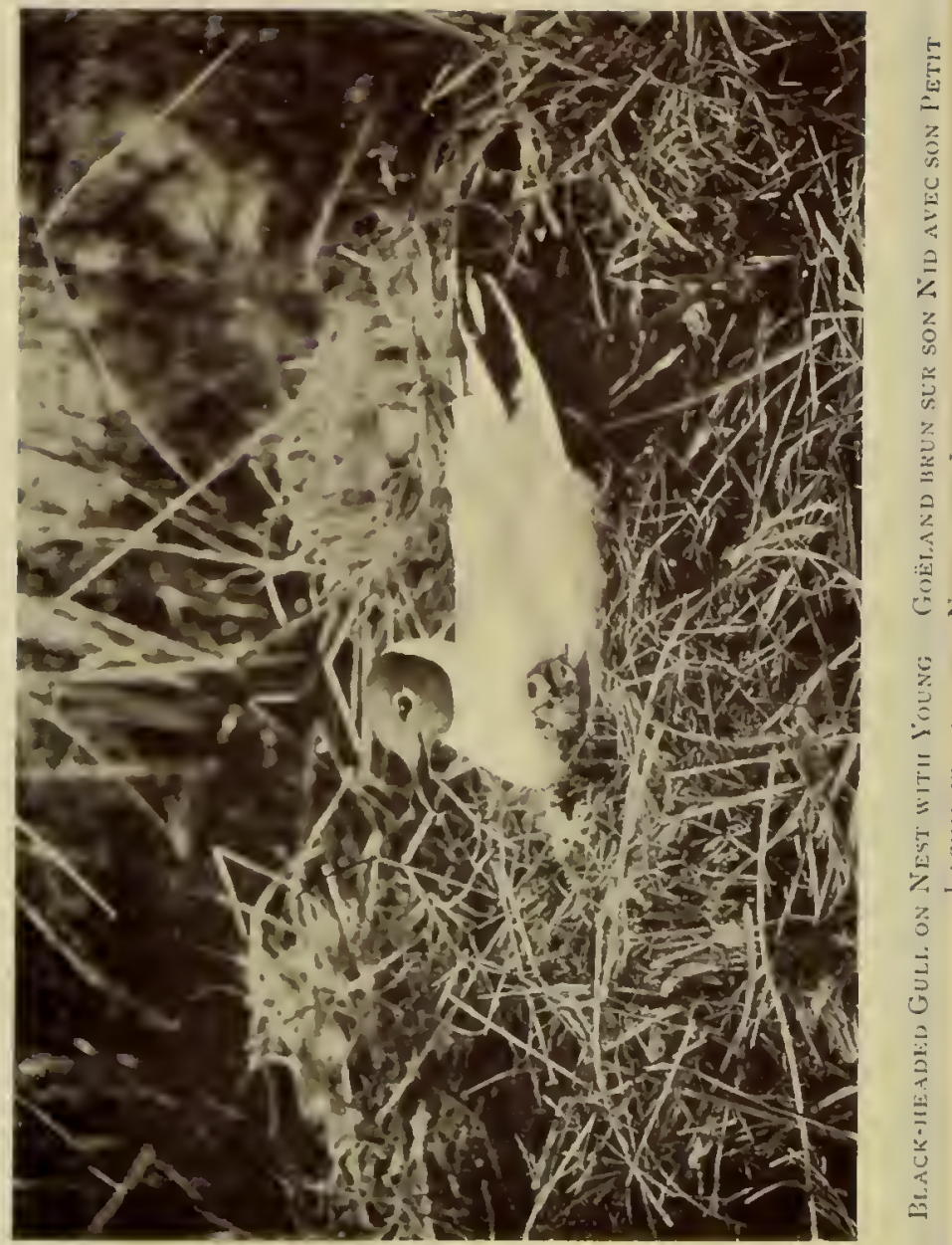




\section{Some Notes on the Birds}

OF WHCH

\section{PHOTOGRAPHS APPEAR IN}

\section{THE FOREGOING PAGES. .}

\section{BY \\ GEORGE GIRDWOOD}

Buzzard (Pages 30.43). - The Buzzard occupies a place in nature between the llawk and the $\mathrm{O}$ w. It is somewhat lieavy both in nppearance and habit, though when in fight its long wings upbear it with great ease, as it circles round and 10 ind in raceful curves watchimg for its prey. Its food consists of young rahbits, field-mire and frogs, and occasionally it may destroy young birds. The colour above is ashy-lurown, the under parts dull while, the breast clouded with a shade of brown, the wing and iail feathers dark brown crossed with bais of darker hrown. The Bumard is deserving of careful protection, but unfortunately its numbers have licen very greatly ieduced through lack of consideration on the part of game preservers. nriginally this bird built its nest in trees, often a fir tree, but of late years it has retreated, during the breeding season at least, to more inaccessible spots where it nesis in clitts. The foundation of the nest is constructed of rough sticks, the upper portion of twigs, and a peculiar habit of the species is to line its uest with fresh green leaves. The eggs are usually three in number, though occasionally four may be found, and are often very handsome. They varv from a dull white without markings, to those where the ground colour is almost obscured by rich blotches and spots of reddish-broun.

Another view of a Buzzard's nest, this rime on a tree, will be found on Page 34 of Wilut Birds at Homi, Second Scries.

Chaffinch (Page 6). - This finch is one of the most brilliantly coloured of our British birds, and the male in spring. When the varied colours of his plumage are at their brightest, with his blue cap, and bright contrast of black, white, and saffron on wings and breast, present: a handsome appearance as he pours out his short but melodious song, or utters his characterictic cry of "pink.pink." The Chafrincb is a resident with us throughout the year, is widely distribuled, and in many districis is ahundan:. The habit of this species, from which it derives its scientific name of "Bachelor. Finch," is that shown in the winter movtls, when the inales and females separase, gathering at that sesion in Hocks, each Hosk 
conposed solely of the one sex. The Cliaffinch is a seed eater, but during the breeding season becomes largely insectivorous, feeding its young on caterpillars, flies, and grubs. The nest of the Chaffinch is exquisitely constructed of moss and lichen, and cosily lined with bair and feathers, and it is not at all uncommon to find worked into the outside small bits of newspaper, oft.times the relic of a paper chase. The nest, often built in the lichen-covered fork of an apple tree, assimilates so closely to its surroundings, as to be difficult of discovery. 'The eggs are usually four in number, greeninh in ground.colour, and streaked and niarled with hrown and black.

This photograpb of the nest and eggs of the Chaffinch completes the series of this bird, as pictures of young will be found on Page 20 of the First Series and Page $2 x$ of the Second Series of Wild Birds at Ifome, and of tle adult bird on Page 22 of the latter. Larger ploosographs will be found on Pages 72 and 73 of Nature Pictures (Guwans \& Gray, Ltd., 7/6 net).

Crow, Carrion- (Pages 18-22). - This bird is a resident, though in winter its numbers are enormously increased by an autunn invasion from the Continent and Scandinavia. Of the Carrion-Crow very little good can be said, while it is unquestionably the source of much trouble and loss to game preservers. In size it is slightly larger than the Rook, whicl it also resembles closely in appearance, the chief distinctions hetween the two being that, while the Rook is alway's gregarious, the Carrion. Crow is a solitary bird, and the latter has at all ages the face feathered, in contrast to the Rook, whicb in its second year loses the facial featbers, presenting that rough and uncouth appearance which is so familiar to all.

The Carrion. Crow bas deservedly earned persecution, with the result that it is now a shy bird and to be found in any number only in tbe more retired and inaccessible parts of our islands, where it resorts to breed. The nest is placed either in crevices amongst rocks, or perhaps more frequently in the branches of a tree growing from a cliff face, though now and again an odd pair may he found nesting in an unexpected situation, such as the corner of a coppice, quite near to human habitation, though in such cases it is unlikely there is a ganekeeper near. The eggs are four or five in number, of a hluish-green ground colour, thickly blotehed, spotted and streaked with olive-brown. The Carrion-Crow is the nearest relative of the Hooded Crow, with which it not infrequently interbreeds, the young in such cases partaking of the cbaracteristics of one of the parents - that is, appearing either all black, as the Carrion. Crow, or with the plumage of the true Hooled Crow.

In colour the Carrion-Crow is blark, with a netaltic lustre of dark steel-hlue, which is particularly apparent in the spring nonths; its length is about 19 inches.

These photographs of the nest and eggs and adult of the Carrion. Crow complete the series of this bird. as pictures of the young will he found on Pages 22 and 23 of Wild Birds at Home, Third series. See also Page 127 of Nafure Picfures (Gowans \& Gray, Lit., $7 / 6$ net).

Gull, Black-headed (Pages 62.54). - This bird should really be called the Brown-headed Gull, the feathers of its head being dark brown, though in contrast to the white of the rest of its plumage appeasing black; or better still, the Comnou Gull, as it is tbis bird 
which is inost commonly to be seen of the Gull tribe. But this lavt name has been given Ly ornithologists to Larws carns, a comparatively rare litd which is to be observed only on our remoler masts, and ont lying isles, and is not very plentiful even there. The 1:ia.k-hended (iull is to be seen on our tidal rivers, feeding at such prints as where the sewage of our towns enters, and in winter it hitunts the neighbourhood of our riverside towns, whete it hak become very tante of late years, frequenting at that season even suich I usy ruaces ns the 'lluames limbankment, where it is fed by the benevolent. In spring this bird resorts to marshy moors and locisa where it breeds, usually in colonies, nuking a nest of rushes and grasses sufficiently high to raise its eggs clear of the water. "llhe ass, iwn, three, or rarely four in number, are variable in colour: a cumnon type is darkinh green in ground colour, spotted and lifutched with black and bruwn. This $t$ ird is a good friend in mant, and in spring and autumm unay be seen following the plough, picking IIP grombs and worms as they are upiurned, and by the contrast of the silver white of its plumage against the dark earth ever ploviding a neasing picture.

Other photographs of adult Black.hexded Gulls will be found on Pages 45 and 46 of the first Series and on l'ake 5 ts of the Second Series of Wild lirids at Hams. For anotber tine series of photo. graphs of this bird, see Pakes 98,99 , and in of Nisiure Pictures (Ciowalls \& Gray, Lid., 7/6 net).

Heron, Common (Pages 37.50 ). - The Heron is resident with w thronghout the year, thought it changes its quarters according to the se:sion. In the autumn months, when the tront run up to sfrww in the head-water of the streaus, the Heron follows them to the high moorland where these rise. It may frequently be seen in the winter inouths on the shores of our rivers aul estuaries. It measures sume 30 iuches in lenzth. has a yellow bill fully" 5 inches long, and long legs of a dull yellowish coluur. Its plumage is light ashy. Erey, the crown of head crested, white in the centre, wih a band of black on each side, ending in the crest in two drmoping black plumes. "The face and neck are whire, streaked with black. with droping plumes of narrow white feathers on foreneck and chest. The under parts are white.

This bird was the favourite quarry in olden times of the falconer and was able, so far, 20 defend itself by means of its powerful bill against an attack of the Falcon which, however, was usually nuccessful in the end, by reason of its superior power of flighis enahling it to rise above the Heron and in that position to strike it partly from behind and thus beyond the range of the bayonet-like hill. It is probable that $\mathrm{nt}$ one tine the Heron nested in marsbes, and it is indeed an unlikely, bird to use its present site, which is usually the top of high tro, where it builds a large nest some four feet in diameter.

Herons breed in colonies, which are not infrequent, but which nsually oecur in private grounds where the birds meet with some neasure of protection. A visit to $\mathrm{Heronry}$ is productive of much interest, and the peculiar flight of the bird made with legsextented traight behind it, and the neck drawn back and resting hetween th: shoulsers, is very similar to the pictures of Storks in flight sn eommon ia Japanoce art. The wings of tbe Herou are leng 
and particularly broad in proportion to the size of the body, and its flight, though swift, does not appear to be so, owing to the slow. measured beats of its broad wings.

The Heron, wbile fishing, presents patience personified, as it stands knee deep in the water, often motionless for a long time. When, however, a fish approaches within reacb, its motion is swift as it darts its beak on its prey, which it usually transfixes. In addition to fish, of which its favourites are trout and eels, it also preys onl frogs and rats, which it swallows whole. The writer bas taken from the stoniach of a full-grown male Heron, a rat fully seven inches long, the skull of which had been broken evidently by the bird's bill.

In certain districts in Ireland, wbere rivers and lakes are num. ercus but where trees are absent, the Heron is found nesting in the scrub or on the ground, on islands in lakes, and it has also been found nesting on sez cliffis. It is shy and wary at most seasons, but less so during the nesting-time. It is an early breeder, the egg: being in ordinary seasons laid by the end of March; these number three, four, or five, and are of a greenish.blue with dull surface. Tbe young remain in the nest till fully fledged, when tbey clamber out, and, before taking flight, may be seell climbing among the brancbes near the nest, using their bill to bold on by and so prevent themselves from falling.

The:e photographs of the nest and eggs and young of the Heron complete the series of this bird. as pictuses of the adult bird are tn be found on Pages 33.39 of Wild birds at Home, Fourth Series. Other fine photographs of nest, eggs, and young, will be found on Pages Io and is of Nature Pictures (Gowans \& Gray, Ltd., $7 / 6 \mathrm{net})$.

Jackdaw (Pages 15.17). - The Jackdaw is a near relative of the Rook, which it resernbles closely in plumage, and with which it ascociates, mixed flocks of both species heing frequently observed feeding together. It is smaller than the Rook, being only 13 inches in length. Its bill is of a similarly powerful type, but measures only $I / 3$ inches, while the outstanding difference between the two birds is that the black with purplish-greenish gloss of the Rook's plumage is in the Jackdaw modified on the head, the crown of wbich shades off in'o grey, and on the nape and lower sides of neck into a dull white The iris is of a bright grey, giving the bird an alert and penetrative look.

The species is widely distributed throughout the British I<les, and is resident, while each winter brings over to us from the Continent a large addition to its numbers in tbe sbape of immigranis who leave again in the spring.

Tbe Jackdaw is gregarious and usually nests in colonies. Its favourite site is a hollow tree, but it is also commonly found nesting in holes in clifts, and in old buildings, $u$ hile in districts where these do not occur, it frequently nests in rabbit.burrows. The nest is an untidy mass of sticks and inoss lined with grass, wool, and sometimes feathers. The eggs number from three to six, and are of a pale-blue gronnd colour, with grey shell markings, and spotted and blotched with greenish brown. In dry seasons the number of eggs is usually linited to three, and the dificulty the old birds find in procuring food leads often to a great mortality amongst the young. 
In general character this bird is impuclent and noisy. Its ealt resembles the word "chack." lis fool consists of worma, ginhs, the egges and young of otleer hircls, grain, peas and fruit, and, in their season berch mast and ar orns, but it is $n o t$ particular and preys upon carrion when occin hion offers.

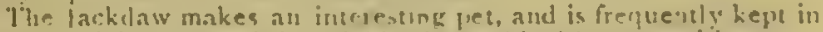
sem-captivity, where it invariably showe thievi-h proponsities.

The writer helieses that the. rlisalpesarance of the Chough from mang of its nesting-place: is due more in the yrecies being ousted by the lackolaw than to any opher te:unus.

For inother plotograph of the nest and eggs of the Jackdaw ree II ild Birds at linme, fisurth bericrs, Page 23. A fine photo. graph of an aduls bird will be found on l'age 84 of stasure f'ictures (Gowans \& Ciray, J.td., 7/6 net).

Jay (Faces 7.14). - The Jay was at one time common, but has been so much shot down by garleners, and more e-precially ly gamekerpers, that it is now cnmparatively ararce. In winter the numbers of our native hirds are largely added to by inmigrants from the Continent. As the Jay is undoubtedly responsihle for the disappearance of a large number hoth of eges and young bircts it is ruthlessly destroyed hy the gamekemper, and, in addition, it hears the penalty of the bright lifue featliers it shows on either wing. which are mucl, in demand for trout llies. Naturally shy and wary. these characteristics have been intensified by the persecitton it hais met with, and it still manages to survive in certain districts, though in Ireland it is stated to be nearly extinct.

The Jay measures some 13 inches in length. Its bill is strong and powerful, being over an inch long. 'The general culour of the plumage is viuous-brown, the crown of the head streakert witl black and distinctly crested, throat white with a broad black moustachual streak above, the forehead whitish with black stresks, while the outstanding features of the pluniage are the wing-patehes of a bright blue barred with hlack. The iris is pale blue, giving a keen aler: look to the hird. "I he note of the lay" is a harsh chattering sound, ieiembling "Clıaick." The Jay feeds on worne, siders, grubs, and, as above mentioned, robs freely" the nests of other birds. devouring both eggs and young. See the remarkably interesting. and probably unique, pholograph on Page 14 . It is also fond of fruit and peas, and in the autumn consumes great rumbers of acorns, its partiality for which is alluded to in the scientific name given to the bird. The flight is latooured, and performed $"$ ith rap d lirating of the wings: but the birl, though capzbie of exiended thight, is seldom to be seen in the open, and is most usually to te oberved flying from tree to tree. It frequents wooded districts, where, in the fork of a tree. the nest is usually placed at some distance from the ground: the persecution to which the species has been subjerted ceems to be encouraging it to build at an increaving heiglit. Tlie nest is formed of twigs and rooss, lined with fine roosters, and is strong and compaci, thoush from the oussile it reems to $b=$ loovely constructed. The efgs sury from three 10 seven, usually five or six, of a clay colour, so thickly clouded witb minute pale-brown spots as to seem of a uniform browsish tinge. Tbore are frequestly thin black lines on the larger end. 
Kestrel (Page 49-56). - The Kestrel is the commonest of our British hawks, and is a harmless inoffensive lird, but alas! to the undiscriminating eye of the gamekeeper, a hawk is a hawk, and the mouse-loving "windhover" has oft-times to fall the victim of his gun. The food of the Kestrel consists almost cntirely of mice and beetles, and it is while in pursuit of the former, tbat it may so frequently be seen hovering bigh in air, there poised for a few seconds absolutely motionless, ere it darts down to seize the mouse it has been watching. The Kestrel is a handsome bird, the gencral colour above dull chestnut, with a black spot in the centre of each feather, in the male bird the head and neck are steely-blue, as is also tbe tail, the latter being tipped with white; the tbroat is buff, the breast and undersides reddish-fawn, streaked with black. In the female the blue of the head and tail is abcent. The Kestrel is partially nigratory, but is found in Britain througbout the year. In the winter it will leave the high lands and descend to avail itself of the less severe conditions of the lower lying parts. A number nigrate to the Continent, while an immigration of a certain number takes place to the British Isles from more northern countries. The Kestrel nests in cliffs, old ruins, or even in the old and deserted nest of a crow or wood-pigeon. The eggs, four, five, or even as many as seven in number, are white in fround colour, but often this is so thickly blotched and spotted witb brownish.red as to be barely visible.

A photograph of egg and young of the Kestrel will be found os Page 42 of the Secend series, and another of young on Page 33 of the Third Scries of Wild Bird's at Honte. See also Pages 69 arid 360 of Nature f'ictures (Gowans \& Gray, Ltd., $7 / 6$ net).

-

Kingfisher (Pages 27.29). - The Kingfisher is probably the mox brilliantly coloured of all our Britisb birds. It is a small bird, measuring only 7 inches in length. Its beak is disproportionately long, measuring $1 \mathrm{f}$ inches. It's plumage is greenish.blue, and possesses in many parts a hright metallic lustre. The back is brigluter blue, the crown on head has bands of dusky black, sides of bead orange-red, with a check stripe of bright blue with dusky bars. while on each side of the neck there is a band of wbite. The under parts are a rich orange-red. The bill is black, and the feet coralred. Tbe species is widely distributed in Britain, and is resident, though largely migratory, within our isles. In suminer the King. fisher frequents rivers, streams, lakes, and ponds, but in winter usually leaves the latter for running water. It is especially fond of such pools as are fringed by snall trees and bushes. Unfortunately the brilliant colouration of the Kingfisher makes it in attractive object to the so-called sportsman, while its feathers are in large domand for trout fies, witb the result that its numbers are now much less than formerly, thougb it is found to be again increasing in districts where it is protected.

Its food consists of small fish, tadpoles, water-beetles, and other insects. If the Kingfisher does destroy a few small trout, the harru to the sport of the angler is surely compensated by the beanty and interest the bird presents, and it is a memorable aght to see a pair of Kingfishers quarrelling, which is not unusuat, or to note the bird"s rapid fligbt as, with slirill cry, it passes suiftly up stream with rapldly beating wings and bill beld straight out in froot. The 
Kingfither excavates a short cunnel in the sandy hank of atream or pool, in which it nests. 'Tle eggs are usually six or seven in number, thongh occasionally eighe or evell nine nay to found. They are purs white, very glossy, and almost round.

The bircls habit is to sit on an exposed branch overhanging the water, watching for lassing fish, which it captures loy plunging w tis quite a loud splash, thereafier emerging unually with a cmall fish helel across the unidile. After regaining its percls its grip is shited to near the fish's tail. It then hangs it on the branch, tosses it in the air, amil, cleftly caugltt, it is swallowed head foremost.

These pltotograples of youmg and adult Kingfislaers ioniplete 1 lie series of this bird, as pictures of its nest and eggs are to be fuund on Pages 29 and 30 of W'ihd Birds at beme, fowrth Sorics.

Nightiar (Pages 23.36). - The Nightjar rejoices in a variety of names, being known also as the Goat.Sucker, tern Owt, l:vejast, Night Hawk and Churn Owl. It is some rots inches in length, with a very short bill 2 little over half an.inch lung, but very wide, as is indeed necessary to enable it to capture the latrge moths aud other inset:ts on which it almost ensirely feects.

In colour this hird is a dark ashy-grev, mottled with brown, and barrel and spotted with streaks of dark cinuamon. The shroat is brown, barred with darker hrown and with white spots, while tliere is in whice parch on either cheek.

The species is a summer visior to our Islea, arriving ahous bire -nd of May and lenving for warmer climes duning September. It is widely spread, but hy no neans common. Its favourite hatunt is moor and woodland, perticularly where fern aud brackey are found, and it seems to prefer tluse parts of the moor which fringe tie wnolland. It is 10 be seen only in the twilight and night hours, when its churring nnte may be heard as it nies lack atsd forword bawking for cockchafers and moths. It is said to feed al-o on rings and caterpillars. It makes no nert. but laye on the ground its twe oges, creamy-whice in ground colour, marbled with violet-grey and Tight shades of brown. When on the nest the colour of the bird so dosely assimilates to its surroundings as to render it almost invicible. Two peculiarities of the Nightjar are a habit of striking its wings wether over its back as it rises in flight, and its manner of ronstung. which is always lengthwise instead of acrn:s the branch on which it rests. T'wo noticeable features in this bird are the strong rectile bristles surrounding the bill and the pectinated claw on the middle toe of either font. The use of this claw has been the subject of many - onjectures, the likeliest of which probalsly is tbat it is used 10 clmau off from the bristles surrounding the bill any small insects which may have heen caught thereon while the bird is hawking after the inoth: on which it nostly lives.

It is interesting to note the origin of its name of Goat-Sucker. Cattle browsing in the twilight disturb many insects from th- grass. and as these are of much interest to the Nizhtjar, it may be seen Aying clowely round the animals, seizing the insects as iney rise. 'The hird's close proxinity' in the animal gave rise to the lu ficrow - wujecture that it perfornted the act its nane suggest.

"l here are two fine (and larger) pholograplis of the young and adult of the Nightjar on Page $\$ 47$ of Nature Ficiules (Gowads 8 . Uray, $;(6)$ net). 
Sparrow-Hawk (Pages 44-48), -This hold raptorial bird is resident with us during the year, and, despite the most persistent persecution of the species hy the gamekeeper over the length and breadth of the land, still inanages to maintain itself in considerable numbers The fenale is, as throughout the raptorial family, con. siderably larger than the male, and it is unfortunately unquestionalble that she destroys, especially at the breeding season, numlers of the young of the game birds near whose baunts she invariahly nests. The site selected by the Sparrow. Hawk for nesting purposes, is frequently a corner of a wood or on the edge of a glade inside a wood, and so suitahle a position does this site appear to be that pair after pair of Sparrow. Haw'ks may be shot from the nest only to be replaced each succeeding year by another couple. The male is blue black above. the breast white suffused with brown, harred with a darker shade of brown, while his mate is rather lighter in colonr, the breast white barred with ashy.grey. The legs of hoth are yellow, with toes greatly developed, giving great grasping power, and ending in needle-pointed talons. The eggs. five or six in number, are of bluish.u.hite ground colour, richly blotched and marked with reddish-brown.

Another photograph of nest and eggs of the Sparrow.Hauk will he found on Page 23 of the First Series, and of young and adult on Pages 31 and 32 of the Third Series of Wild Rivels at Home. See also Page 160 of Nisture Pictures (Gowans \& Gray, Ltd., 710 net).

Whitethroat (Frontispiece). - The Whitethroat is a summer migrant, reaching Britain in April, is extremely numerous and very widely distrihuted, and rejoices in a bewildering variety of local nanes, such as "Chairlie Gahhie," " "l hisky Tam," "Nettle Creeper," etc. The song of the Whitethroat consists of a medley. and gives the hearer the impression that the hird is very fussy, and it is uttered in a hurried querulous twittering fashion, almost as though in anger. It is while uttering its song that the distinctive feature tn which it owes its name hecomes most visible, its head being raised and the pale coloured feathers of the throat distended. The Whitethroat is ahout five and a half inches long, is greyish brown above, the head ashy.grey, while the under surface of the body iv white with the breast faintly' washed with vinous colour. This sp-cies is insectivorous in habit, and is especially fond of the "Daddy Long Legs," hut in the autumn months feeds on currants and berries. Favourite haunts of the Whitethroat are the tangled patches of brambles on the margins of the woodland, old cnuntry lanes, and overgrown liedgerowa, where, in the tangled half.open growth of bramble and hriar, its deep but slender nest may by careful search be discovered. It is huilt of dry grass, and lined with horse hair, is frequently placed aunid the hrambles, sometimes amidst nettle stemis and contains four to six eggs. greenish-yellow in ground colour, thickly spotted with faint marks of violet-grey:

This photograph of the nest and eggs of the Whitethroat com. vletes the series of this bird, as pictures of the young and adult will be found on Pages 12.14 of Will birds at Home, Second Serics. See'also Page $3^{1}$ of Niature Pictures (Gowans \& Gray, Lid., 7/6 Gar net). 


\section{N DEX}

TO

\section{BIRDS REPRESENTED IN SERIES $\mathrm{l}-\mathrm{V}$ \\ $\mathrm{OF}$}

"WILD BIRDS AT HCME"

\section{EXYCIIISII}

Blackbird. I, 6, 7; 11, 6.8

Bullfinch. IV, I8

Bunting, Reed-. II, 23, 24

Bunting, Yellow. I, a

Buzzard. II, 34; V, 30.43

Capercaillie. 1I, 52 : III. 45

Chaffinch. I, 20; II, 21, 22: $v, 6$

Chough. IV, ig

Coot. I $Y, 47$

Cormorant. III, 34-33

Crow, Carrion-. III, 22, 13 : $\mathrm{V}, \mathrm{x}^{8.22}$

Cuckoo. II, 23; III, 27.30

Curlew. I, 43, 44

Dipper. III, 7.0

Dove, Ring -. $\{11,44.4 \uparrow$

Dove, Stock-. II, 5 ?

Duck, Eider. III, 40.43

Duck, Sheld.. Ill, 30

Duck, Wild. See Mallard

Dunlin. I1, 55

Flycatcher, Spotted. I, 17: III, 16

Gannet. I, $35-32 ; 11,43 \cdot 47,60$

Goldfinch. IV, $: 2,: 3$

Goose, Solan. See Gannet

Grebe, Great Crested. 11, 64

Greenfinch. III, $\mathbf{1 7 \cdot 2 0}$

Grouse, Red. II, 53, 54

Guillemot. I 53.6a; I1. 6x, 6a

Gull, Lesser Black-backed. I, 48,$40 ;$ II, $57 ; 111,64$

Gull, Black-headed. I, $+5,+5$; II, $56 ; \mathrm{V}, 6_{2} \cdot 6_{4}$

Gull, Herring-. I, 47

Gull, Kittiwake. I, 50.53;

$$
\text { II, } 53,59
$$

Hammer, Yellow. See Bunt. ing, Yellow.

Hawk, Sparrow. 1,23; III, 31,$32 ; V, 44 \cdot 48$

Heron, Common. IV, 33.39;

$$
\text { V. } 57.59
$$

Jackdaw. IV, $23 ; V, 25-39$

Jay. $1,7 \cdot 14$
Kestrel, II, 42; III, 33 ; V. 49.56

Kingfisher. IV, 29. 30 :

V. 27.20

Lapwing. 1, 3

Lark, Sky-. YI, 26.29

Linnet. IV, 15, 15

Magnie. IV, 20.22

Mallard. I, 34: IV, $4 \cdot 43 ; \mathrm{V}$, 60,61

Martin, House.. IV, 2,6, ,

Martin, Sand-. IV, B.rI

Merganser, Red-breasted. II. 50

Merlin. I, $24 ; 11,35.4 \mathrm{r}$

Moor-hen. I, $37 ;$ IV, $45,4^{5}$

Nightjar. $v, 23.26$

Ouzel, Ring-. II. 9

Ouzcl, Water.- lice Dipper

Owl, Barn-. See Owl, White.

Owl, Little. $\mid V, 3 x, 32$

OwI, Long-eared. II, $29 \cdot 3$ ?

Owl, Tawny. $11,32,33$

Owl, White. I, 22

Oyster-catcher. III, 50, 53

Partrisge. 1, 36

Petrel, Storm-. 1V. 49.54

Pheasant. 1 35 Sor Dove, Ring -

Pipit, Meadow-. 1, 86: III, 14. 15.33

Pipit, Rock.. II, so

Plover, Ringed, III, $47 \cdot 40$

Puffin. I, $\sigma_{3}, \sigma_{4} ; I I, \sigma_{3}$

Rail, Water-. IV, 44

Raven. IV, 24

Razorbill. I. $54 \cdot 57$; II, 50

Redbreast. II, 10, II

Redpoll Lesser. IV, I?

Redshank. $1,41,42 ; I^{2}, 43$

Redstart. III, 2. 6

Rook. II, 25: III, 2426

Sandpiper, Common. I, to

Shearvvater, Manx. IV, 5.64

Silpe, Common. 111, $52 \cdot 34$ 


\section{INDEX}

Sparrow, Hedge-. I, I3

Sparrow, House-. I, ro; IV, 14

Starling. III, 2I

Swallow. 1, 18

Swan, Mute. I, 33; IV, to

Swift. IV, $25 \cdot 28$

Teal. II, 48, 49

Tern, Arctic. III, $66_{1}-6_{3}$

Tern, Common. III, 58-60

Tern, Sandwich. 111,55-57

Thrush, Mistle-. V, 14
Thrush, Song-. I, : II,

Titmouse, Blue. I, 35

Titmouse, Great. II. I5, 16

TItmouse, Long-talled. I, 34 ; III, 10-13

Warbler, Sedge.. I, I

Water-hen. See Moor-hen

Whitethroat. $11,12 \cdot 14 ; \mathrm{V}, 2$

Woodcock. I, 39

Wren. II, $17 \cdot 19$

Wren, Willow-. I, 8.ri

\section{LATIN}

Accentor modularis. I, $\times 3$ Accipiter nisus. I, 23; III, 31,$32 ; V, 44-48$

Acredula caudata. I, 14; III, 10.13

Acrocephalus phragmitis. $I, x=2$

Alauda arvensis. II, 26.28

Alca torda. I, 54.57; II, 3o

Alcedo ispida. IV, 29,$30 ; \mathrm{V}$. $27-29$

Anas boscas. I, 34; IV, 4I. $43: \mathrm{V}, 60,6 \mathrm{r}$

Anorthura iroglodytes. Sec Troglodytes parvulus

Anthus obscurus. I1, 20

Anthus pratensis. I, 6 ; III, I $4, \times 5,30$

Ardea cinerea. IV, 33-39: V, 57.59

Asio otus. II, 29.31

Athene noctua. IV, 31, 32

Buteo vulgaris. 11,$34 ; \mathrm{V}$, 30.43

Cinclus aquaticus. III, 7.9

Caprimulgus europaus. V, $23 \cdot 26$

Carduelis elegans. IV, $12, x_{3}$

Chelidon urbica. IV, 2, 6, 7

Columba anas. II, 5 I

Columba palumbus. $111,44,45$

Corvus corone. III, 22, 23 ; $\mathrm{V}, \times 8.22$

Corvus corax. IV, 34

Corvus fruglegus. II, 25 : III, $24 \cdot 26$

Corvus monedula. IV, $23 ; \mathrm{V}$, $15-17$

Cotile riparia. IV, 8 . II

Cuculus canorus. II, 23; 111, $27 \cdot 30$

Cypselus apus. $I V, 25 \cdot 28$

Cygurs olor. I, $33 ; I V, 40$
Emberiza citrinella. I, ar

Emberiza schœniclus. II, s; 24

Erithacus rubecula. Il, ra, Ix

Falco xsalon. I, 24; II, 35. 18 Falco buteo. Sic Buteo vul. garis

Falco timnunculus. II, 4E; 111,$33 ; \mathrm{V} .49 \cdot 56$

Fratercula arctica. I, $\sigma_{3}, 6_{4}$; II, 63

Fringilla caelebs. I, so; II, 21,$22 ; V, 6$

Fulica atra. IV, 47

Gallinago colestis. III, $52 \cdot 54$ Gallinula chloropus. I, 37 ; IV, 45,46

Garrulus glandarius. $V, 7 \cdot 14$

Hirundo rustica. I, 18

Homatopus ostralegus. III, 5o, 51

Lagopus scotlcus. II, 53, 54

Larus argentatus. I, 47

Larus fuscus. $I, 48,49 ; 1 I, 57$; III, $6_{4}$

Larus ridibundus. I, 45, 46; II, 56; V, 62.64

Ligurinus chloris. III, 17-20

Linota cannabina. IV, $15,{ }^{16}$

Linota rufescens. IV, 77

Mergus serrator. II. 50

Motacilla sylvia. Sie Sylvia cincrea

Muscicapa grisola. I, r7: 111,16

Nettion crecca. I1, 48, 4 4

Numcrius arquata. I, 43,44

Egialitis hiaticola. III, $47^{\circ}$ 
Parus caruleus. 1, 15

Parus major. 11. 15, 16

Passer domesticus. I, 19 ; IV, 14

Perdix cinerea. I, 36

Phalacrocorax carbo. III, $34 \cdot 3^{8}$

Phasianus colchicus. I, 35

Phylloscopus trochilus. 8.11

Pica rustica. IV, 20.22

Puffinus anglorum. IV, 5564 Podicipes cristatus. $[1,64$

Procellaria pelagica. IV, $40^{\circ}$ 54

Pyrrhocorax graculus. $1 \mathrm{~V}, 19$ Pyrrhula europaa. IV, 18

Rallus aquaticus. IV, 44

Rissa tridactyla. I, 50.53; II, 58,50

Ruticilla phonicurus. III, 2, 6

Scolopax rusticula. I, 30

Solnateria mollisima. III, 40.13
Sterna cantiaca. III 55.57

Sterna fluviatilis. III, 88.60

Sterna macrura. $\quad 11], 61 \cdot 63$

Sturnus vulgaris. III, II

Strix flanmea. I, az

Sula bassana. I, 25.32;11, 43 47,60

Sylvia cinerea. $11,12 \cdot 14 ; \mathrm{V}, 2$

Syrnium aluco. II, 32, 33

Tadorna cornuta. III, 39

Tetrao urogallus. II, 52 ; III, 46

Totanus calidris. $1,41,42$; IV. $4^{3}$

Totanus hypoleucus. I, to

Tringa alpina. 11, 55

Troglodytes parvulus. 11, 1719

Turdus merula. I, $6,7: I I$, 6.8

Turdus musicus. $1,2: 11,2$

Turdus torquatus. 11,9
Turdus viscivorus. $V, 84$

Uria troile, I. $58.62 ; 11.61,62$

Vanellus vulgaris. $1,3^{8}$ 


\section{NOVELTIES, :: : : CHRISTMAS, I 9 IO.}

1. MARY QUEEN OF SCOTS. A Poem by Henry Glassford Bell. With four photogravure illustrations after Robert Herdman, R.S.A. Paper Cover, 6d. net.

2. MASTERPIECES OF LYRICAL TRANSLATION.

Uniform with "Lyric Masterpieces by Living Authors." Parchment Cover, 6d. net.

3. LES CHEFS-D'CUURE LYRIQUES DE VICTOR HUGO. Choisis par Auguste Dorchain. Parch. ment, 6d. net; Cloth, 1s. net; Leather, 2s. net.

4 'TURNER'S LIBER STUDIORUM. Miniature Edition, with all the unpublished plates. Paper Is. net; Cloth, 1s. 6d. net; Leather, 25. 6d. net.

5. CLYDE SONGS AND OTHER VERSES, by J. J. B., author of "Wee Macgreegor." Cloth, 28. 6d, net, Limited Edition on Handmado Paper, 58. net.

6. THE GARDEN OF SHADOWS. A Norel by James MacNab, 2s. 6d. net.

Also New Volumes in other Series (See Art Books, Nature Books, etc.). 


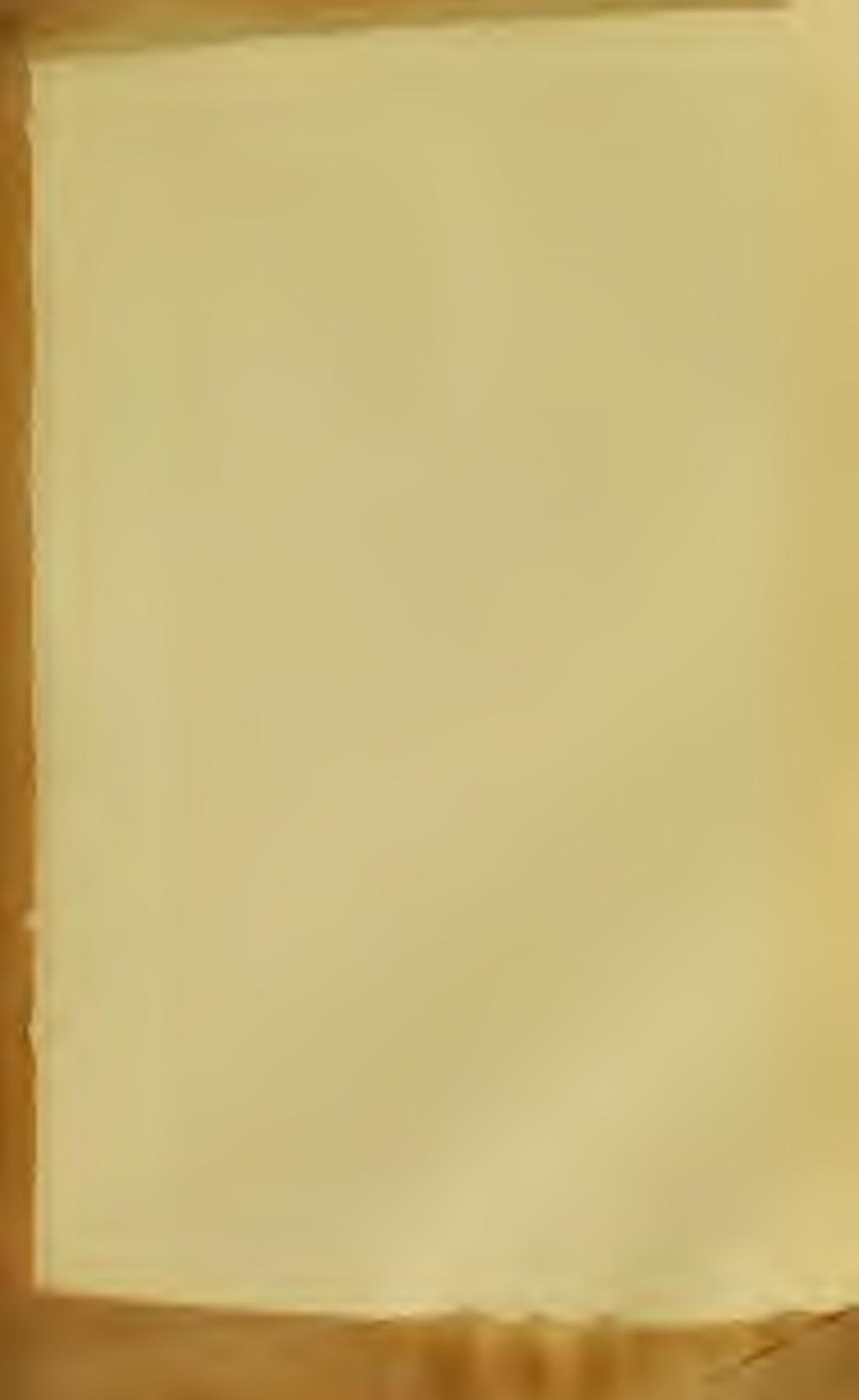


